University of Nebraska - Lincoln

DigitalCommons@University of Nebraska - Lincoln

Faculty Publications from the Harold W. Manter Laboratory of Parasitology

2001

\title{
Gastrointestinal Strongyles in Wild Ruminants
}

Eric P. Hoberg

United States Department of Agriculture, ehoberg@ggpl.arsusda.gov

A. Alan Kocan

Oklahoma State University - Main Campus

Lora G. Rickard

Mississippi State University

Follow this and additional works at: https://digitalcommons.unl.edu/parasitologyfacpubs

Part of the Parasitology Commons

Hoberg, Eric P.; Kocan, A. Alan; and Rickard, Lora G., "Gastrointestinal Strongyles in Wild Ruminants" (2001). Faculty Publications from the Harold W. Manter Laboratory of Parasitology. 623.

https://digitalcommons.unl.edu/parasitologyfacpubs/623

This Article is brought to you for free and open access by the Parasitology, Harold W. Manter Laboratory of at DigitalCommons@University of Nebraska - Lincoln. It has been accepted for inclusion in Faculty Publications from the Harold W. Manter Laboratory of Parasitology by an authorized administrator of DigitalCommons@University of Nebraska - Lincoln. 


\title{
GASTROINTESTINAL STRONGYLES IN WILD RUMINANTS
}

\author{
ERIC P. HOBERG, A. ALAN KOCAN, AND LORA G. RICKARD
}

INTRODUCTION. Parasitologists have long studied helminth infections in wildlife species and have documented the existence of many organisms from a diversity of mammalian hosts. With this accumulation of information has come improved understanding of the significance of these organisms and the diseases they produce in their mammalian hosts. Some of the most notable examples include the metastrongyloid lungworms, Trichinella spiralis, and Elaeophora schneideri, which are covered separately in this volume. It is, however, for the group of parasites referred to as gastrointestinal nematodes that we have accumulated the most data. Only recently has progress been made in determining the significance of these strongylate nematodes with respect to their potential impact on the morbidity and mortality of the ruminants that they infect.

The accumulation of information on diseases of wild animals into a single combined volume has been slow, but progress has coincided with the proliferation of data for host and parasite interactions. Numerous references including Alaskan Wildlife Diseases (Dieterich 1981), Manual of Common Wildlife Diseases in Colorado (Adrian 1981), Field Manual of Wildlife Diseases in the Southeastern United States (Davidson and Nettles 1988), Zoo and Wildlife Medicine (Fowler 1993), and the previous editions of Parasitic Diseases of Wild Mammals (Davis and Anderson 1971) have all made significant contributions to our knowledge. Beyond North America, Dunn (1969) and Govorka et al. (1988) provided excellent compilations on the helminths in wild ruminants. In the 1971 printing of Parasitic Diseases of Mammals, however, there was no general coverage of gastrointestinal nematodes, and only $T$. spiralis was addressed. Herein, we present the first synoptic review of the strongylate nematodes that occur in the gastrointestinal system of wild ruminants from North America.

Context for Assessing the Nematode Fauna. Strongylate nematodes are among the most characteristic parasites of the gastrointestinal system of ruminants throughout the world. A substantial literature encompassing systematics, ecology, and pathology has developed over the past century, particularly with reference to those species of direct veterinary importance that infect domestic bovids (e.g., Levine 1980; Lichtenfels and Hoberg 1993; Hoberg and Lichtenfels 1994; Lichtenfels et al. 1997). Although there is recognition of the potential influence of gastrointestinal nematodes on morbidity and mortality in sylvatic bovids and cervids, typically there have been only superficial assessments of these parasites within the context of wildlife management (e.g., Chapman and Feldhamer 1982).

Substantial research has been conducted on the systematics, diagnosis, and impact of gastrointestinal nematodes, but significant problems remain to be resolved. These include (1) standardization of methods for survey including sampling and necropsy of hosts; (2) uniformity in collection and preservation of nematode specimens; (3) consistency in parasite taxonomy; (4) adoption of a populational approach to studies of wildlife disease; and (5) application of a modern context for systematics, biodiversity assessment, and biogeography (Brooks and Hoberg 2000).

Although the procedures necessary for collection, identification, and enumeration of gastrointestinal nematodes in wild ruminants are often tedious and time consuming, they provide critical data for understanding epizootiology and the patterns of disease (see Eve and Kellogg 1977; Jordan and Stair 1983). It is necessary to document the significance of the parasite present and to carefully record the clinical signs that are observed. In keeping with a broader or population-based approach, it is also critical to derive information not associated with epizootics or mortality events. A standardized nomenclature for quantitative descriptors of parasite populations is encouraged (e.g., Bush et al. 1997).

Issues dealing with identification of eggs, freeliving infective larvae, and early-stage parasitic larvae to the level of genus and species are of continuing importance (Lichtenfels et al. 1997). Lack of such reliable information represents a primary gap in our abilities to develop sound and predictive epizootiological models for the circulation of parasites in sylvatic host populations.

Consequently, the development of "epizootiological probes" derived from molecular biology and systematics will substantially influence our abilities to monitor the contemporary geographic range, patterns of transmission, and host distribution. The sensitivity and specificity of molecular markers applied to the identification of larvae and eggs could reduce reliance on current methods of parasite diagnosis that are dependent upon collection and necropsy of hosts and identification of adult helminths. Elimination of collecting has particular significance when linked to requisite studies 
Hoberg, Kocan \& Rickard in Parasitic Diseases of Wild Mammals (Samuel, Pybus \& Kocan. eds.). lowa State University Press, 2001, 2nd ed.

of the influences of parasitism on morbidity, mortality, and population dynamics of endangered species. Such would represent a novel approach to simultaneously assess parasitism in wild ruminants across large geographic regions. Species-specific markers, for instance those that can be derived from the ITS region of genomic DNA [e.g., Christiansen et al. $(1994 \mathrm{a}, \mathrm{b})$ for some trichostrongylids and Campbell et al. (1995) for some strongyles], are the primary requirement for development and realization of this methodology. This will provide an unprecedented application of molecular systematics and diagnostics, and for the first time make it feasible to develop a synoptic understanding of the scope of parasitism in populations of free-ranging sylvatic bovids and cervids.

Only recently have the theoretical and empirical implications of parasitism in wildlife and sylvatic ruminants, exclusive of direct mortality, been examined in greater detail (e.g., Grenfell 1988, 1992; Gulland 1992; Arneberg et al. 1996; Folstad et al. 1996). Through this body of research we have begun to recognize the often subtle influence of parasites and the feedback linkages between hosts, parasites, and habitat stability. They have also emphasized the importance of assessing the impacts of parasitic diseases at the level of host population within a rigorous theoretical framework (Gulland 1995; Grenfell and Gulland 1995; Hudson and Dobson 1995; Shaw and Dobson 1995). These areas of research are beyond the typical realm of investigating disease at the level of individual hosts. They are, however, an integral component in the development of an understanding of epizootiology, and the potential for density-dependent impacts on host demographics (Grenfell and Gulland 1995).

Biodiversity assessment and biogeographic analysis are important basic components to studies in parasitology and wildlife disease (Hoberg 1997; Brooks and Hoberg 2000). The nematode faunas in ruminants from North America and their relationships to those in Eurasia (see Govorka et al. 1988) are only now becoming adequately defined. Concepts developed from historical studies in the arctic and boreal zones can be applied directly to elucidating the evolution of nematode faunas among ruminants. We are only now beginning to unravel the anthropogenic and natural influences on diversification and distribution of this fauna (e.g., Hoberg et al. 1999). The origins and history of the North American fauna are complex, but must be elucidated in order to understand the distributional patterns for parasites and the potential for disease.

The contemporary strongylate fauna is a mosaic of archaic and introduced elements. Endemic (archaic) strongyles were influenced by historical movements of bovids and cervids across the Beringian nexus linking Eurasia and North America beginning 10-20 million years ago and extending into the Pliocene and Pleistocene. Secondarily, with the introduction of domestic stock starting in the fifteenth century and continuing today, numerous additional species associated with bovids were introduced and became established in North America. The interaction between archaic and introduced faunas and the subsequent potential for exchange of strongyles between domestic and sylvatic hosts have in large part been determined by these historical and contemporary events. Thus, to understand the current strongylate fauna and its distribution in North American ruminants, it is necessary to recognize the context of biogeography and the historical constraints on the distribution of these host-parasite assemblages across the Holarctic (Hoberg and Lichtenfels 1994; Hoberg 1997). It is becoming apparent that a number of cryptic species representing this archaic fauna and currently unrecognized by science may be parasites in sylvatic hosts (Lichtenfels and Pilitt 1989; Lichtenfels et al. 1997; Hoberg et al. 1999). Both components of this fauna, however, have implications for management practices in North America and serve to reemphasize the importance of translocation of hosts on the distribution of parasites (see Hoberg 1997).

Recent studies among the ostertagiines, or medium stomach worms, and other nematodes have continued to identify the role of translocation of hosts and the introduction of parasites as factors determining the continental and international distribution of some pathogens (e.g., Thornton et al. 1973a,b; Rickard et al. 1993; Van Baren et al. 1996; Hoberg 1997). Studies of this type further emphasize the importance of systematics and taxonomy in providing a predictive framework for identification, documentation, and subsequently, surveillance (Brooks and Hoberg 2000). Incomplete documentation of the biodiversity of this fauna, including geographic range, host distribution, and the number of species involved (cryptic species), hampers the development of control measures to limit the impact of potentially pathogenic species of strongyles and other parasites. Accurate survey and inventory of the North American fauna is critical with respect to recognizing the potential emergence of pathogens and the interactions between parasite faunas circulating in domestic and sylvatic hosts.

Many of the changes that wildlife managers and parasitologists are now experiencing are related to overabundance of some bovids or cervids. Increased contact between domestic and sylvatic animals as well as the proliferation of game ranching and the farming of wild animals emphasize the importance of assessing wildlife diseases. Anthropogenically driven global change, particularly habitat alteration and the concomitant impact on the distribution of hosts, also highlights the significance of wildlife disease research, including parasitology, related to endangered species and conservation biology.

Strongylate Nematodes and Their Hosts. Strongylate nematodes representing three superfamilies, Ancylostomatoidea, Strongyloidea, and Trichostrongyloidea have been reported as parasites of the gastrointestinal system in wild bovids and cervids in North America. 
The trichostrongyloid nematodes are dominant in terms of taxonomic, genealogical, and numerical diversity (e.g., Durette-Desset 1985; Hoberg and Lichtenfels 1994) and, consequently, are among the most significant as recognized or potential pathogens. Higher-level systematics for the Ancylostomatoidea and Strongyloidea is consistent with Lichtenfels (1980a,b) and disregards a recent proposal to elevate these and other related strongyles to the rank of suborder (DuretteDesset and Chabaud 1993). Systematics for the Trichostrongyloidea is consistent, in part, with that proposed by Durette-Desset (1983), with modifications related to the Trichostrongylidae based on Hoberg and Lichtenfels (1992, 1994). Phylogenetic relationships among the trichostrongylids and taxonomy within the family remain to be resolved, although current hypotheses share a high degree of similarity (Hoberg and Lictenfels 1994; Durette-Desset et al. 1999).

The following treatment presents a comprehensive view of the North American fauna including current knowledge for gastrointestinal strongyles in (1) six species of sylvatic bovids (pronghorn, Antilocapra americana; bison or buffalo, Bison bison; mountain goat, Oreamnos americanus; Rocky Mountain bighorn sheep, Ovis canadensis; Dall's sheep, Ovis dalli; and muskox, Ovibos moschatus), (2) five species of cervids (moose, Alces alces; elk or wapiti, Cervus elaphus; mule or black-tailed deer, Odocoileus hemionus; white-tailed deer, $O$. virginianus; and caribou, Rangifer tarandus), and (3) three species of primary domestic hosts (cattle, Bos taurus; sheep, Ovis aries; and llama, Llama glama) (Tables 8.1-8.12). Ancillary information is outlined on the occurrence of helminths in (1) introduced cervids (axis deer, Axis axis; red deer, Cervus elaphus elaphus; sambar, $C$. unicolor; fallow deer, $C$. dama; Pere David's deer, Elaphurus davidianus; and sika deer, C. nippon), (2) exotic bovids (addax, Addax nasomaculatus; blackbuck, Antilope cervicapra; sable antelope, Hippotragus niger; and gemsbok, Oryx beisa), and (3) camelids (Llama glama), pertinent to game ranching and maintenance of free-ranging herds (Tables 8.13 and 8.14). This provides the context for elucidating the occurrence of strongylate nematodes in wild and domestic bovids and the linkages within this assemblage of parasites and hosts.

Among wild ruminants in North America, 54 species of strongyles in 16 genera have been reported (Table 8.1 ); 21 in the abomasum, 28 in the small intestine, and 6 in the large intestine; some species occur in both the abomasum and the small intestine. This total does not include nematodes identified only at the level of family or genus reported in some studies. Additionally, not included among these, but discussed below, are a number of species and genera so far only associated with domestic or exotic hosts and several which could potentially be introduced from the Palearctic, Eurasia, and Africa (Tables 8.13 and 8.14). The relatively few species limited in occurrence solely to sheep or cattle are not addressed.

\section{GASTROINTESTINAL STRONGYLES IN NORTH AMERICAN RUMINANTS}

\section{Genus Monodontus Molin, 1861}

Classification: Ancylostomatoidea:

Ancylostomatidae: Bunostominae.

Common Name: Hookworm of deer.

Monodontus louisianensis Chitwood and Jordan, 1965.

Monodontus louisianensis is a typical, but relatively uncommon parasite of the small intestine in $O$. virginianus across the southern United States (Prestwood and Pursglove 1981; Forrester 1992). It is the only hookworm known from sylvatic cervids or bovids in North America. The life cycle is currently unknown, but likely involves direct cutaneous penetration of the definitive host by third-stage larvae ( $\mathrm{L}_{3}$ 's), similar to those documented for other hookworms (Prestwood and Pursglove 1981). Prevalence and intensity in white-tailed deer from Florida are 20\%-100\% and 1-13 worms per host (Forrester 1992). Disease associated with this nematode has seldom been documented in white-tailed deer and may be associated with weather conditions that concentrate deer in damp, fecal-contaminated areas that are conducive to transmission. Clinical signs would be expected to parallel those described for hookworm disease and anemia typical of other ruminants but are unlikely to be observed due to the low numbers of parasites usually present in parasitized hosts (Prestwood and Pursglove 1981).

\section{Genus Eucyathostomum Molin, 1861}

Classification: Strongyloidea: Strongylidae:

Cyathostominae: Eucyathostominae.

Common Name: Colon worms.

Eucyathostomum webbi Pursglove, 1976. [Synonym: There are records of E. longisubulatum Molin, 1861 from white-tailed deer in Florida and South Carolina according to Pursglove (1976).]

Species of this genus are known as parasites in the colon of artiodactyls, particularly cervids, with one species being typical of white-tailed deer across the southern United States (Pursglove 1976; Prestwood and Pursglove 1981). Prevalence and intensity for white-tailed deer from Florida are $11 \%-80 \%$ and $1-26$ worms per host (Forrester 1992). Diagnosis is based on the specific structure of the cephalic extremity (cervical inflation and leaf crowns) and the male copulatory organs, which are distinctive (Pursglove 1976; Lichtenfels 1980b). The life cycle is unknown, but consistent with other cyathostomes it is likely to be direct. Disease attributable to this nematode is apparently negligible, as infections generally are of low intensity.

Genus Chabertia Railliet and Henry, 1909

Classification: Strongyloidea: Chabertiidae: Chabertiinae.

Common Name: Large-mouthed bowel worms. 
TABLE 8.1-Strongylate nematodes in North American ruminants: A comparison of faunas in wild bovids, cervids, and domesticated sheep, cattle, and camelids

\begin{tabular}{|c|c|c|c|c|c|c|c|c|c|c|c|c|c|c|}
\hline & \multicolumn{6}{|c|}{ Bovidae } & \multicolumn{5}{|c|}{ Cervidae } & \multicolumn{3}{|c|}{ Domestic $^{a}$} \\
\hline & $\begin{array}{l}\text { Prong- } \\
\text { horn }\end{array}$ & Bison & $\begin{array}{l}\text { Mountain } \\
\text { Goat }\end{array}$ & $\begin{array}{l}\text { Bighorn } \\
\text { Sheep }\end{array}$ & $\begin{array}{l}\text { Dall's } \\
\text { Sheep }\end{array}$ & $\begin{array}{l}\text { Musk- } \\
\text { ox }\end{array}$ & Moose & Elk & $\begin{array}{l}\text { Mule } \\
\text { deer }\end{array}$ & $\begin{array}{c}\text { White- } \\
\text { tail }\end{array}$ & $\begin{array}{l}\text { Cari- } \\
\text { bou }\end{array}$ & Cattle & Sheep & Lama \\
\hline \multicolumn{15}{|l|}{ Abomasum } \\
\hline Haemonchus spp. & + & - & - & + & - & - & - & - & - & - & - & + & + & + \\
\hline H. contortus & + & + & - & + & - & - & + & - & + & + & - & + & + & - \\
\hline H. placei & + & - & - & + & - & - & - & - & - & + & - & + & + & - \\
\hline H. similis & - & - & - & - & - & $\ldots$ & - & - & - & + & - & + & - & - \\
\hline Marshallagia spp. & - & - & + & + & - & + & - & - & 一 & - & - & - & - & - \\
\hline M. marshalli & + & - & + & + & + & + & - & + & + & - & + & - & + & - \\
\hline Mazamastrongylus pursglovei & - & - & - & - & - & - & - & + & - & + & - & - & - & - \\
\hline M. odocoilei & - & - & - & - & - & - & - & + & - & + & - & - & - & - \\
\hline Obeliscoides cuniculi & - & - & - & + & - & - & - & - & - & + & - & - & - & - \\
\hline Ostertagia spp. ${ }^{b}$ & + & - & + & + & - & + & + & + & + & + & + & + & + & - \\
\hline O. bisonis & + & + & - & - & - & - & - & - & + & - & - & + & - & - \\
\hline O. gruehneri & - & - & - & - & - & + & - & - & - & - & + & - & $\ldots$ & - \\
\hline O. leptospicularis & - & - & - & - & - & - & - & + & + & - & - & + & - & - \\
\hline O. mossi & - & - & - & - & - & - & -. & - & - & + & + & - & - & - \\
\hline O. ostertagi & + & + & + & + & + & - & - & + & + & + & - & + & + & + \\
\hline Pseudostertagia bullosa & + & - & - & + & - & - & - & - & + & - & - & - & + & - \\
\hline Spiculopteragia spiculoptera & - & - & - & - & - & - & - & - & - & + & - & - & - & - \\
\hline Teladorsagia spp. & - & - & - & + & - & + & - & - & - & - & - & - & - & - \\
\hline T. boreoarcticus & - & - & - & - & - & + & - & - & - & - & + & - & - & - \\
\hline T. circumcincta & + & - & + & + & + & + & - & - & + & + & + & - & - & + \\
\hline Trichostrongylus spp. & - & - & - & + & - & + & + & - & - & - & - & + & + & - \\
\hline T. askivali & - & - & - & - & - & - & - & - & - & + & - & - & - & - \\
\hline T. axei & + & + & + & + & - & - & - & + & + & + & + & + & + & + \\
\hline T. calcaratus & - & - & - & - & - & - & - & - & - & + & - & - & - & - \\
\hline T. colubriformis & - & - & + & + & - & - & - & + & - & 一 & - & + & + & - \\
\hline T. dosteri & - & - & - & - & - & - & - & - & - & + & - & - & - & - \\
\hline T. longispicularis & - & - & - & - & - & - & - & - & - & + & - & + & + & + \\
\hline \multicolumn{15}{|l|}{ Small Intestine } \\
\hline Cooperia spp. & + & - & - & + & - & - & - & + & - & + & - & + & + & + \\
\hline C. curticei & - & - & - & - & - & - & -. & - & - & + & - & + & + & - \\
\hline C. oncophora & + & + & - & + & - & - & - & + & + & + & - & + & + & + \\
\hline C. pectinata & + & - & - & - & - & - & - & - & - & + & - & + & + & - \\
\hline
\end{tabular}


Hoberg, Kocan \& Rickard in Parasitic Diseases of Wild Mammals (Samuel, Pybus \& Kocan. eds.). lowa State University Press, 2001, 2nd ed.

\begin{tabular}{|c|c|c|c|c|c|c|c|c|c|c|c|c|c|c|}
\hline C. punctata & + & - & - & - & - & - & - & - & - & + & - & + & + & 一 \\
\hline C. spatulata & - & - & - & - & - & - & - & - & - & + & - & + & + & - \\
\hline C. surnabada & + & + & - & + & - & - & - & - & + & - & - & + & + & + \\
\hline Cyathostominae gen. sp. & + & - & - & - & - & - & - & - & - & - & - & - & - & - \\
\hline Monodontus louisianensis & - & - & - & - & - & - & - & - & - & + & - & - & - & - \\
\hline Nematodirus spp. & + & - & + & + & + & + & + & + & -- & + & + & + & + & - \\
\hline N. abnormalis & + & - & - & + & - & - & - & - & + & - & - & - & + & - \\
\hline N. andersoni & - & - & - & + & + & - & - & - & - & - & - & - & - & - \\
\hline N. archari & - & - & - & + & + & - & - & - & - & - & - & - & - & - \\
\hline N. becklundi & - & - & + & - & - & - & - & - & - & - & - & - & - & - \\
\hline N. davtiani & - & - & + & + & + & - & - & - & - & - & - & - & + & - \\
\hline N. filicollis & + & - & + & + & - & - & - & -. & + & + & + & - & + & + \\
\hline N. helvetianus & - & + & + & + & - & + & - & + & + & - & - & + & - & + \\
\hline N. maculosus & - & - & + & + & - & - & - & - & - & - & - & - & - & - \\
\hline N. odocoilei & - & - & + & + & - & - & - & + & + & + & + & - & - & - \\
\hline N. oiratianus & - & - & - & + & + & - & - & - & - & - & - & - & + & - \\
\hline N. oiratianus interruptus & + & - & + & + & + & - & - & - & - & - & - & - & + & - \\
\hline N. spathiger & + & - & - & + & + & - & $\ldots$ & - & + & - & - & - & + & + \\
\hline N. skrjabini & - & - & - & - & - & + & - & - & - & - & + & - & - & - \\
\hline N. tarandi & - & - & - & - & - & + & + & - & - & - & + & - & - & - \\
\hline Nematodirella spp. & - & - & - & - & + & + & - & - & - & - & - & - & - & - \\
\hline N. alcidis & - & - & - & - & - & + & + & + & - & - & + & - & - & - \\
\hline N. antilocaprae & + & - & + & + & - & - & - & + & + & - & - & - & - & - \\
\hline N. gazelli & - & - & - & -- & - & + & - & - & - & - & - & - & - & - \\
\hline N. longissimespiculata & + & - & - & - & - & + & + & - & + & - & + & - & + & - \\
\hline Trichostrongylus spp. & + & - & + & + & - & - & - & + & + & + & - & + & + & + \\
\hline T. colubriformis & + & - & - & - & - & - & - & - & + & - & - & + & + & - \\
\hline T. longispicularis & - & - & - & - & - & - & + & - & + & - & - & + & + & + \\
\hline T. vitrinus & - & - & - & - & - & - & - & - & + & - & - & - & + & + \\
\hline $\begin{array}{l}\text { Large Intestine/Cecum } \\
\text { Chabertia ovina }\end{array}$ & - & + & 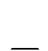 & + & - & 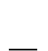 & 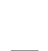 & 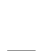 & + & 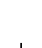 & & 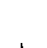 & 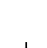 & 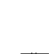 \\
\hline Eucyathostoma webbi & - & 工 & - & - & 二 & 二 & - & - & \pm & + & 二 & $\stackrel{+}{+}$ & \pm & - \\
\hline Oesophagostomum spp. & - & + & - & + & $\ldots$ & _- & - & - & + & - & - & + & + & 二 \\
\hline O. cervi & - & - & - & - & - & - & - & - & - & + & - & - & - & - \\
\hline O. columbianum & - & - & - & - & - & - & - & - & - & + & - & - & + & - \\
\hline$O$. radiatum & - & + & - & - & - & - & - & - & - & - & - & + & - & - \\
\hline O. venulosum & - & - & + & - & - & - & + & + & + & + & - & + & + & + \\
\hline
\end{tabular}

aData for domestic hosts primarily from Becklund (1964) and Rickard and Bishop (1991).

"Minor morphotypes for polymorphic species of ostertagiines are not listed. 
TABLE 8.2-Strongylate nematodes in pronghorn, Antilocapra americana

\begin{tabular}{|c|c|c|}
\hline Location/Species & Locality (State/Province) & Source $^{\mathrm{a}}$ \\
\hline \multicolumn{3}{|l|}{ Abomasum } \\
\hline Haemonchus contortus & ND, SD, TX & $2,6,9,11,16$ \\
\hline H. placei & NM & \\
\hline Haemonchus sp. & WUS $^{b}$ & 10 \\
\hline Marshallagia marshalli & MT, SD, WY, WUS & $1,6,9,10,13$ \\
\hline Ostertagia bisonis & ND, SD, WY, WUS & $2,7,8,9,10,16$ \\
\hline O. ostertagi & MT, ND, NM, SD, WY, WUS & $2,9,10,14,16$ \\
\hline Ostertagia sp. & SD, WY & 9 \\
\hline Pseudostertagia bullosa & MT, NM, SD, WY, WUS ${ }^{\mathrm{h}}$ & $2,6,9,10,14$ \\
\hline Teladorsagia circumcincta/ & MT, ND, SD, WY, WUS & $2,9,10,16$ \\
\hline Trichostrongylus axei & NM, WUS ${ }^{b}$ & 10,14 \\
\hline \multicolumn{3}{|l|}{ Small Intestine } \\
\hline Cooperia oncophora & ND, NM, SD, WUS & $2,6,10,12,14,16$ \\
\hline C. pectinata & NM, WUS & 10,14 \\
\hline C. punctata & NM, WUS & 10,14 \\
\hline C. surnabada & SD & 2 \\
\hline Cooperia sp. & NM & \\
\hline Nematodirella antilocaprae & $\begin{array}{l}\mathrm{AB}, \mathrm{ID}, \mathrm{MT}, \mathrm{ND}, \mathrm{NM}, \\
\text { OR, SD, TX, WY }\end{array}$ & $3,4,9,11,13,14,15,16$ \\
\hline N. longissimespiculata & SD & 2 \\
\hline Nematodirus abnormalis & SD, WUS ${ }^{b}$ & $6,9,10$ \\
\hline N. filicollis & ND, WUS ${ }^{b}$ & 10,16 \\
\hline N. oratianus interruptus & NM & 5,14 \\
\hline$N$. spathiger & MT, ND, SD, WUS ${ }^{b}$ & $2,6,9,10,16$ \\
\hline Nematodirus sp. & SD & \\
\hline Trichostrongylus colubriformis & MT, ND, NM, SD, WUS & $6,9,10,14,16$ \\
\hline Trichostrongylus spp. & NM & 14 \\
\hline Cyathostominae ${ }^{e}$ gen. sp. & WY & 9 \\
\hline
\end{tabular}

a1. Bergstrom (1975a). 2. Boddicker and Hugghins (1969). 3. Durette-Desset and Samuel (1989). 4. Lichtenfels and Pilitt (1983b). 5. Lichtenfels and Pilitt (1983a). 6. Lucker and Dikmans (1945). 7. Worley and Sharman (1966). 8. Lichtenfels and Pilitt (1991). 9. Unpublished records, U.S. National Parasite Collection. 10. Allen (1962). 11. Hailey et al. (1966). 12. Burtner and Becklund (1971). 13. Bergstrom (1975b). 14. Gilmore and Allen (1960). 15. Shaw (1947). 16. Goldsby and Eveleth (1954).

${ }^{\mathrm{b}}$ Western United States.

'The distribution of $T$. circumcincta and associated minor morphotypes requires confirmation based on molecular analyses (Hoberg et al. 1999).

¿Specimens identified as Nematodirella longissimespiculata by Boddicker and Hugghins (1969), were redetermined as $N$. antilocaprae by Lichtenfels and Pilitt (1983b).

"Unidentified "cylicostomes" collected by R. Bergstrom from Sweetwater County, WY.

Chabertia ovina (Fabricius, 1794). [Synonyms: Strongylus ovinus Fabricius, 1794; S. hypostomus

Rudolphi, 1819; S. cernuus Creplin, $1819 ; C$. rishati Akhtar, 1937

Large bowel worms are considered rare or incidental parasites of wild bovids and cervids and have only been reported from Odocoileus spp., Ovis canadensis, and $B$. bison. It is probable that these parasites are acquired on common range with domesticated hosts including cattle and sheep. The life cycle is direct. Disease is unknown in wild hosts, possibly due to the low intensity and sporadic nature of infections. At high intensity, these blood-feeding parasites would be expected to cause severe diarrhea, loss of weight and condition, and the development of anemia (Levine 1980).

\section{Genus Oesophagostomum Molin, 1861}

Classification: Strongyloidea: Chabertiidae:

Oesophagostominae.
Common Name: Nodular worms.

Oesophagostomum cervi Mertts, 1948. [Synonym: Considered by Baker and Pursglove (1976), and Levine (1980) to be a synonym of $O$. venulosum, this species has been reported from the southeastern United States, with an argument that it is distinguishable from the former (Payne et al. 1967). Govorka et al. (1988) list it as one of a number of species of Oesophagostomum in Eurasian cervids.] Oesophagostomum columbianum Curtice, 1890.] Oesophagostomum radiatum (Rudolphi, 1803). [Synonyms: Bosicola radiatum Sandground, 1929; B. tricollaris Sandground, $1929 ; O$. inflatum (Schneider, 1866); O. dilatum (Railliet, 1884); $O$. bovis Schnyder, 1906; O. biramosum Cuillé, Marotel and Panisett, 1911; O. vesiculosum Rátz, 1898].

Oesophagostomum venulosum (Rudolphi, 1809). [Synonyms: S. follicularis Ostertag in Olt, 1898; $O$. 
TABLE 8.3-Strongylate nematodes in buffalo or bison, Bison bison

\begin{tabular}{|c|c|c|}
\hline Location/Species & Locality (State/Province) & Source $^{\mathrm{a}}$ \\
\hline \multicolumn{3}{|l|}{ Abomasum } \\
\hline Haemonchus contortus & $\mathrm{AB}, \mathrm{KS}, \mathrm{OK}, \mathrm{SD}$ & $4,5,7$ \\
\hline $\begin{array}{l}\text { Ostertagia bisonist } \\
\text { O. cf. kazakhstanica }\end{array}$ & $\mathrm{AB}, \mathrm{AK}, \mathrm{KS}, \mathrm{SD}, \mathrm{WY}$ & $2,4,6,7,9,11,12$ \\
\hline $\begin{array}{l}\text { O. ostertagi } \\
\text { O. lyrata }\end{array}$ & $\mathrm{AB}, \mathrm{KS}, \mathrm{WY}$ & $1,4,12$ \\
\hline Trichostrongylus axei & $\mathrm{AB}, \mathrm{KS}$ & 4 \\
\hline \multicolumn{3}{|l|}{ Small Intestine } \\
\hline Cooperia oncophora & $\mathrm{AB}, \mathrm{AK}, \mathrm{SD}, \mathrm{WY}$ & $3,4,7,11,12,13$ \\
\hline C. surnabada & $\mathrm{AK}, \mathrm{SD}$ & 7,11 \\
\hline Nematodirus helvetianus & $A B, W Y$ & $8,12,14$ \\
\hline Strongylida?? & UT, WY & 10,15 \\
\hline \multicolumn{3}{|l|}{ Large Intestine } \\
\hline Chabertia ovina & SD & 7 \\
\hline Oesophagostomum radiatum & $\mathrm{AB}, \mathrm{KS}, \mathrm{MT}, \mathrm{OK}, \mathrm{WY}$ & $4,5,12$ \\
\hline Oesophagostomum sp. & $\mathrm{AB}, \mathrm{MT}$ & 1,12 \\
\hline
\end{tabular}

a 1. Cameron (1923, 1924). 2. Chapin (1925). 3. Cram (1925). 4. Dikmans (1939). 5. Locker (1953). 6. Becklund and Walker (1967b). 7. Boddicker and Hugghins (1969). 8. Bergstrom and Kass (1982). 9. Lichtenfels and Pillitt (1991). 10. Van Vuren and Scott (1995). 11. C. A. Nielsen, unpublished data. 12. Unpublished records, U.S. National Parasite Collection. 13. Burtner and Becklund (1971). 14. Card (1993). 15. Zaugg et al. (1993).

"Boddicker and Hugghins (1969) reported $O$. trifurcata in bison. The minor morphotype associated with $O$. bisonis is considered to be $O$. kazakhstanica according to Lichtenfels and Pilitt (1991). Reexamination of USNPC 59388 showed the specimen reported by Boddicker and Hugghins to be incorrectly identified, and it is tentatively referred to $O$. kazakhstanica, a new North American record for this ostertagiine. Drózdz (1995), however, has indicated that the minor morphotype associated with O. bisonis in North America may be undescribed.

\section{TABLE 8.4-Strongylate nematodes in mountain goat, Oreamnos americanus}

\begin{tabular}{|c|c|c|}
\hline Location/Species & Locality (State/Province) & Source ${ }^{a}$ \\
\hline \multicolumn{3}{|l|}{ Abomasum } \\
\hline $\begin{array}{l}\text { Marshallagia marshalli }{ }^{\mathrm{b}} \\
\text { M. occidentalis }\end{array}$ & $\mathrm{AB}, \mathrm{AK}, \mathrm{ID}, \mathrm{WA}, \mathrm{WY}$ & $3,4,5,6,10,11,13$ \\
\hline Ostertagia ostertagi & $\mathrm{AB}, \mathrm{SD}$ & $2,4,6$ \\
\hline Ostertagia sp. & $A B, W A, W Y$ & \\
\hline Teladorsagia circumcincta/ ${ }^{\circ}$ & $\mathrm{AB}, \mathrm{SD}$ & $2,4,6,11,12,13$ \\
\hline \multicolumn{3}{|l|}{ T. trifurcata } \\
\hline Trichostrongylus axei & SD & 2 \\
\hline T. colubriformis & SD & 2 \\
\hline \multicolumn{3}{|l|}{ Small Intestine } \\
\hline Nematodirella antilocaprae & SD & 7 \\
\hline Nematodirus becklundi & $\mathrm{AB}$ & 9 \\
\hline N. davtiani & $\mathrm{AB}$ & 13 \\
\hline N. filicollis & $\mathrm{AB}$ & 4 \\
\hline N. helvetianus & $\mathrm{AB}, \mathrm{SD}, \mathrm{WA}$ & $2,11,13$ \\
\hline N. maculosus & $\mathrm{AB}, \mathrm{MT}, \mathrm{SD}$ & $1,2,6,13$ \\
\hline N. odocoilei & $\mathrm{AB}, \mathrm{MT}$ & 11 \\
\hline N. oiratianus interruptus & $\mathrm{AB}$ & 8 \\
\hline Nematodirus sp. & SD & 12 \\
\hline Trichostrongylus sp. & $\mathrm{ID}$ & 3 \\
\hline \multicolumn{3}{|l|}{ Large Intestine/Cecum } \\
\hline Oesophagostomum venulosum & SD & 2 \\
\hline
\end{tabular}

${ }^{2}$ 1. Becklund (1965). 2. Boddicker et al. (1971). 3. Brandborg (1955). 4. Cowan (1951). 5. Dikmans (1942). 6. Kerr and Holmes (1966). 7. Lichtenfels and Pilitt (1983b). 8. Lichtenfels and Pilitt (1983a). 9. Durette-Desset and Samuel (1992). 10. Lichtenfels and Pilitt (1989). 11. Unpublished records, U.S. National Parasite Collection. 12. Boddicker and Hugghins (1969). 13. Samuel et al. (1977).

'Specimens from O. americanus in Alberta, Alaska, Washington, and Wyoming may represent a distinct species of Marshallagia (see Lichtenfels and Pilitt 1989).

'Specimens of $T$. circumcincta and associated minor morphotypes should be confirmed based on analysis of morphometric and molecular date (see Hoberg et al. 1999). 
Hoberg, Kocan \& Rickard in Parasitic Diseases of Wild Mammals (Samuel, Pybus \& Kocan. eds.).

lowa State University Press, 2001, 2nd ed.

TABLE 8.5-Strongylate nematodes in bighorn sheep, Ovis canadensis

\begin{tabular}{|c|c|c|}
\hline Location/Species & Locality (State/Province) & Source $^{a}$ \\
\hline \multicolumn{3}{|l|}{ Abomasum } \\
\hline Haemonchus contortus & NM, WY & $3,10,11$ \\
\hline H. placei & NM & 1 \\
\hline Haemonchus sp. & $\mathrm{CO}$ & 19 \\
\hline $\begin{array}{l}\text { Marshallagia marshallit }{ }^{\mathrm{b}} \\
\text { M. occidentalis }\end{array}$ & $\mathrm{AB}, \mathrm{BC}, \mathrm{CO}, \mathrm{ID}, \mathrm{MT}, \mathrm{OR}, \mathrm{SD}, \mathrm{WY}$ & $\begin{array}{l}3-8,10,11,14,15,17,18,20,22,27,29, \\
32,33\end{array}$ \\
\hline Marshallagia sp. & $\mathrm{AB}, \mathrm{BC}$ & 20 \\
\hline Obeliscoides cuniculi & $\mathrm{CO}$ & 29 \\
\hline $\begin{array}{l}\text { Ostertagia ostertagil } \\
\text { O. lyrata }\end{array}$ & $\mathrm{BC}, \mathrm{ID}, \mathrm{MT}, \mathrm{SD}$ & $3,4,14,29,32$ \\
\hline Ostertagia sp. & $\mathrm{BC}, \mathrm{CO}, \mathrm{OR}, \mathrm{MT}$ & $6,14,19,33$ \\
\hline Pseudostertagia bullosa & $\mathrm{CO}, \mathrm{NM}$ & 1,16 \\
\hline $\begin{array}{l}\text { Teladorsagia circumcinctal } \\
\text { T. trifurcata } \\
\text { T. davtiani }\end{array}$ & $\mathrm{AB}, \mathrm{BC}, \mathrm{MT}, \mathrm{SD}, \mathrm{WY}$ & $3,4,6,11,20,29,32$ \\
\hline Teladorsagia sp. & $\mathrm{AB}, \mathrm{BC}$ & 20 \\
\hline Trichostrongylus axei & $\mathrm{OR}, \mathrm{SD}$ & 14,29 \\
\hline T. colubriformis & SD & 29 \\
\hline Trichostrongylus sp. & MT & 29 \\
\hline \multicolumn{3}{|l|}{ Small Intestine } \\
\hline Cooperia oncophora & MT, OR, WY & $3,11,14,31$ \\
\hline C. surnabada & MT & 3 \\
\hline Cooperia sp. & MT & 33 \\
\hline Nematodirella antilocaprae & $\mathrm{AB}$ & 9 \\
\hline Nematodirus abnormalis & MT, WY & 11,32 \\
\hline N. andersoni & $\mathrm{AB}$ & 9 \\
\hline N. archari $^{\mathrm{d}}$ & BC, MT, WY & $3,20,21,26$ \\
\hline N. davtiani & $\mathrm{AB}, \mathrm{BC}, \mathrm{MT}, \mathrm{WY}$ & $3,20,23,26,30,32$ \\
\hline$N$. filicollis & $\mathrm{AB}, \mathrm{MT}$ & 6,23 \\
\hline N. helvetianus & MT, SD, WY & $3,24,26,29$ \\
\hline N. maculosus & $\mathrm{AB}, \mathrm{BC}, \mathrm{SD}, \mathrm{WY}$ & $20,26,29$ \\
\hline N. odocoilei & MT & 28 \\
\hline N. oiratianus & $\mathrm{BC}, \mathrm{OR}$ & 14,20 \\
\hline N. oiratianus interruptus $\mathrm{e}^{\mathrm{e}}$ & $\mathrm{AB}, \mathrm{CO}, \mathrm{MT}$ & $3,16,23$ \\
\hline N. spathiger & $\mathrm{BC}, \mathrm{CO}, \mathrm{MT}, \mathrm{NM}, \mathrm{WY}$ & $2,3,11,16,20,23$ \\
\hline Nematodirus sp. & $\mathrm{AB}, \mathrm{BC}, \mathrm{CA}, \mathrm{MT}, \mathrm{OR}, \mathrm{SD}, \mathrm{WA}$ & $4,5,12,13,14,20,22,24,25,29$ \\
\hline \multicolumn{3}{|l|}{ Large Intestine } \\
\hline Chabertia ovina & MT & 32 \\
\hline Oesophagostomum sp. & NM, OR, WA & $1,12,13,14$ \\
\hline
\end{tabular}

a1. Allen (1955). 2. Allen and Kennedy (1952). 3. Becklund and Senger (1967). 4. Blood (1963). 5. Couey (1950). 6. Cowan (1951). 7. Dikmans (1932). 8. Dikmans (1942). 9. Durette-Desset and Samuel (1989). 10. Honess and Scott (1942). 11. Honess and Winter (1956). 12. Johnson (1974). 13. Johnson (1975). 14. Kistner et al. (1977). 15. Marsh (1938). 16. Pilmore (1961). 17. Quortrup and Sudheimer (1944). 18. Rush (1932). 19. Spencer (1943). 20. Uhazy and Holmes (1971). 21. Rickard and Lichtenfels (1989). 22. Boddicker and Hugghins (1969). 23. Lichtenfels and Pilitt (1983a). 24. McCullough and Schneegas (1966). 25. Capelle (1966). 26. Bergstrom and Kass (1982). 27. Bergstrom (1975a). 28. Becklund and Walker (1967a). 29. Unpublished records, U.S. National Parasite Collection. 30. Becklund (1966). 31. Burtner and Becklund (1971). 32. Hoar et al. (1996). 33. Worley and Seesee (1992).

bDrózdz (1995) considers that some Marshallagia in O. canadensis represent an undescribed species.

"Some specimens identified as $T$. circumcincta may represent an undescribed cryptic species; specimens of $T$. circumcincta require confirmation based on morphometric and molecular data (see Hoberg et al. 1999).

${ }^{d}$ Specimens identified as $N$. archari may be referrable to $N$. andersoni [see Durette-Desset and Samuel (1989), Rickard and Lichtenfels (1989)].

'Specimens of $N$. lanceolatus from North America are considered synonyms of $N$. oiratianus interruptus by Lichtenfels and Pilitt (1983a). 
Hoberg, Kocan \& Rickard in Parasitic Diseases of Wild Mammals (Samuel, Pybus \& Kocan. eds.).

lowa State University Press, 2001, 2nd ed.

TABLE 8.6-Strongylate nematodes in Dall's sheep, Ovis dalli ${ }^{\text {b }}$

\begin{tabular}{|c|c|c|}
\hline Location/Species & Locality (State/Province) & Source $^{a}$ \\
\hline $\begin{array}{l}\text { Abomasum } \\
\text { Marshallagia marshallil } M \text {. occidentalis } \\
\text { Ostertagia ostertagi } \\
\text { Teladorsagia circumcincta/ } \\
\quad \text { T. trifurcata } \\
\quad \text { T. davtiani }\end{array}$ & $\begin{array}{l}\text { AK, NWT } \\
\text { AK } \\
\text { AK }\end{array}$ & $\begin{array}{l}1,4 \\
1 \\
1\end{array}$ \\
\hline $\begin{array}{l}\text { Small Intestine } \\
\text { Nematodirella sp.(c.f. N. alcidis) } \\
\text { Nematodirus andersoni } \\
\text { N. archari } \\
\text { N. davtiani } \\
\text { N. oiratianus } \\
\text { N. oiratianus interruptus } \\
\text { N. spathiger } \\
\text { Nematodirus sp. }\end{array}$ & $\begin{array}{l}\text { AK } \\
\text { AK } \\
\text { AK } \\
\text { AK } \\
\text { AK } \\
\text { AK } \\
\text { AK } \\
\text { NWT }\end{array}$ & $\begin{array}{l}1 \\
3 \\
1,5 \\
1 \\
1 \\
2 \\
1 \\
1\end{array}$ \\
\hline $\begin{array}{l}\text { Large Intestine } \\
\text { None reported }\end{array}$ & & \\
\hline
\end{tabular}

${ }^{a}$ 1. Nielsen and Neiland (1974). 2. Lichtenfels and Pilitt (1983a). 3. Durette-Desset and Samuel (1989). 4. Unpublished records, U.S. National Parasite Collection. 5. Rickard and Lichtenfels (1989).

${ }^{b}$ Nematodes apparently only reported from $O$ vis dalli dalli and not from $O$. $d$. stonei.

'Specimens identified as $T$. circumcincta require confirmation based on molecular analyses and may represent an undescribed species (Hoberg et al. 1999)

"Specimens referred to as $N$. longispiculata by Nielsen and Neiland (1974).

eSpecimens referred to $N$. archari may actually represent $N$. andersoni (see Durette-Desset and Samuel 1989; Rickard and Lichtenfels 1989).

TABLE 8.7-Strongylate nematodes in muskox, Ovibos moschatus ${ }^{\mathrm{b}, \mathrm{c}}$

\begin{tabular}{|c|c|c|}
\hline Location/Species & Locality (State/Province) & Source $^{a}$ \\
\hline \multicolumn{3}{|l|}{ Abomasum } \\
\hline Marshallagia marshalli/M. occidentalis & $\mathrm{AK}, \mathrm{NU}^{\mathrm{h}}$ & $1,4,6,7,9$ \\
\hline Marshallagia sp. & NU & 4,7 \\
\hline Ostertagia gruehneri/ O. arctica & $\mathrm{AK}, \mathrm{NU}$ & 7,8 \\
\hline Ostertagia sp. & $\mathrm{AK}, \mathrm{NU}$ & 4 \\
\hline Teladorsagia boreoarcticus & NU, NWT & 11 \\
\hline T. circumcincta/ ${ }^{\mathrm{d}}$ & $\mathrm{AK}, \mathrm{NU}$ & $2,6,8$ \\
\hline $\begin{array}{l}\text { T. trifurcata } \\
\text { T. davtiani }\end{array}$ & & \\
\hline Trichostrongylus spp. & $\mathrm{AK}$ & 3 \\
\hline \multicolumn{3}{|l|}{ Small Intestine } \\
\hline Nematodirella alcidis & NU & 7 \\
\hline N. gazelli $t^{\mathrm{e}}$ & NU & $2,4,5$ \\
\hline N. longissimespiculata ${ }^{\dagger}$ & $\mathrm{AK}$ & 5,8 \\
\hline Nematodirella sp. & $\mathrm{AK}, \mathrm{NU}$ & 4 \\
\hline Nematodirus helvetianus & NU & 4,6 \\
\hline N. skrjabini & $\mathrm{AK}$ & \\
\hline N. tarandi & AK, NU & 7,10 \\
\hline Nematodirus sp. & $\mathrm{AK}, \mathrm{NU}$ & 4,7 \\
\hline $\begin{array}{l}\text { Large Intestine } \\
\text { None reported }\end{array}$ & & \\
\hline
\end{tabular}

${ }^{2}$ 1. Dikmans (1939). 2. Gibbs and Tener (1958). 3. Bos (1967). 4. Samuel and Gray (1974). 5. Lichtenfels and Pilitt (1983b). 6. Webster and Rowell (1980). 7. E. Hoberg, S. Kutz, and J. Nishi, unpublished data from Victoria Island and Cox Lake and Rae River, near Kugluktuk, NU. 8. C. A. Nielsen, unpublished data from Barter Island; specimens in introduced population of whitefaced musk ox, Ovibos moschatus wardi translocated from East Greenland in 1935 to Nunivak Island and subsequently to the Arctic coastal plain in 1969 (see Hoberg et al. 1999). 9. Lichtenfels and Pilitt (1989). 10. Unpublished records, U.S. National Parasite Collection. 11. Hoberg et al. 1999.

bIncluding barrenground musk ox, Ovibos moschatus moschatus, and white-faced musk ox, $O$. m. wardi

'See Alendal and Helle (1983) for a review of records from captive herds; also see MacDonald et al. (1976).

dSpecimens collected from Victoria Island and the mainland on the Rae and Richardson Rivers, near Kugluktuk, NU, represent a recently described cryptic species (Hoberg et al. 1999). Teladorsagia boreoarcticus is represented by two male morphotypes, designated respectively as T. boreoarcticus forma major and $T$. boreoarcticus f. minor. Previous records of $T$. circumcincta from Arctic Canada, and those from other wild bovids across the Holarctic require confirmation (Hoberg et al. 1999).

'Specimens reported as Nematodirella longispiculata by Samuel and Gray (1974) were redetermined as N. gazelli by Lichtenfels and Pilitt (1983b); records by Gibbs and Tener (1958) may represent this species.

${ }^{\text {t}}$ Specimens from Nunivak Island, Alaska, examined by C.A. Neilsen (unpublished) and identified as N. longispiculata, may represent this species (see Lichtenfels and Pilitt 1983b).

EThere is continuing disagreement over the validity of $N$. skrjabini, with some authorities reducing it as a synonym of $N$. tarandi.

${ }^{\mathrm{h}} \mathrm{NU}=$ Nunavut, Canada, a former region of the eastern Northwest Territories. 
TABLE 8.8-Strongylate nematodes in moose, Alces alces

\begin{tabular}{llc}
\hline Location/Species & Locality (State/ Province) & Source $^{\mathrm{a}}$ \\
\hline Abomasum & & \\
Haemonchus contortus & $\mathrm{NWT}$ & 8 \\
Ostertagia sp. & $\mathrm{AB}$ & 3 \\
Trichostrongylus $\mathrm{sp}$. & $\mathrm{MN}$ & 12 \\
Small Intestine & & \\
Nematodirella alcidis & $\mathrm{h}$ & $1-7,9,10$ \\
N. longissimespiculata & $\mathrm{AB}, \mathrm{AK}, \mathrm{BC}, \mathrm{MN}, \mathrm{MT}$ NF, ON & 11 \\
Nematodirus tarandi & $\mathrm{MN}$ & 11 \\
Nematodirus sp. & $\mathrm{AK}$ & 3 \\
Trichostrongylus longispicularis & $\mathrm{AB}$ & \\
Large Intestine & & 6 \\
Oesophagostomum venulosum & $\mathrm{MN}$ & 6 \\
\hline
\end{tabular}

${ }^{a}$ 1. Lichtenfels and Pilitt (1983b). 2. Samuel et al. (1976). 3. Stock and Barrett (1983). 4. Cowan (1951). 5. C.A. Nielsen, unpublished data. 6. Anderson and Lankester (1974). 7. Threlfall (1969). 8. Unpublished records, U.S. National Parasite Collection. 9. Fruetel and Lankester (1988). 10. Hoeve et al. (1988). 11. Unpublished records, U.S. National Parasite Collection. 12. Loken et al. (1965).

'It is apparent that $N$. alcidis represents the correct name for the species that occurs most commonly in moose across North America; $N$. alcidis is a species established for $N$. longispiculata alcidis Dikmans, 1935. Specimens reported as N. longispiculata by Cowan (1951) and Samuel et al. (1976) were redetermined as N. alcidis by Lichtenfels and Pilitt (1983b). Andersen and Lankester (1974) summarized reports of $N$. longispiculata from moose across North America.

TABLE 8.9-Strongylate nematodes in elk or wapiti, Cervus elaphus

\begin{tabular}{lll}
\hline Location/Species & Locality (State/ Province) & Source $^{\mathrm{a}}$ \\
\hline Abomasum & & $6,7,9$ \\
Marshallagia marshalli & $\mathrm{WY}$ & 5,7 \\
Mazamastrongylus odocoilei & $\mathrm{MI}$ & 3 \\
M. pursglovei & $\mathrm{CA}$ & 3 \\
Ostertagia leptospicularis/ O. kolchida & $\mathrm{CA}$ & $2,9,10$ \\
Ostertagia ostertagi & $\mathrm{NM}$ & $2,3,8,10$ \\
Ostertagia sp. & $\mathrm{AB}, \mathrm{WY}$ & 8 \\
(reported as Skrjabinagia) & $\mathrm{AB}, \mathrm{CA}, \mathrm{NM}$ & \\
Trichostrongylus axei & $\mathrm{NM}$ & 2,10 \\
T. colubriformis & & 7,9 \\
Small Intestine & $\mathrm{AB}$ & 2,10 \\
Cooperia oncophora & $\mathrm{MI}, \mathrm{WY}$ & 1,4 \\
Cooperia sp. & $\mathrm{AB}$ & $1,2,10$ \\
Nematodirella alcidis & $\mathrm{SD}$ & 7 \\
N. antilocaprae & $\mathrm{AB}, \mathrm{SD}$ & 9 \\
Nematodirus helvetianus & $\mathrm{MI}$ & 9 \\
N. odocoilei & $\mathrm{WY}$ & \\
Nematodirus sp. & $\mathrm{WY}$ & 1,7 \\
Trichostrongylus sp. & & $\mathrm{MI}$ \\
Large Intestine & $\mathrm{MD}$ & \\
Oesophagostomum venulosum & $\mathrm{B}$ & \\
\hline
\end{tabular}

a 1. Boddicker and Hugghins (1969). 2. Stock and Barrett (1983). 3. Van Baren et al. (1996). 4. Lichtenfels and Pilitt (1983b). 5. Lichtenfels et al. (1993). 6. Bergstrom (1975a). 7. Unpublished records, U.S. National Parasite Collection. 8. Wilson (1969). 9. Worley (1979). 10. Thorne et al. (2001).

${ }^{\mathrm{b}}$ Specimens reported as $N$. longissimespiculata by Boddicker and Hugghins (1969) were redetermined as $N$. antilocaprae by Lichtenfels and Pilitt (1983b). 
Hoberg, Kocan \& Rickard in Parasitic Diseases of Wild Mammals (Samuel, Pybus \& Kocan. eds.). lowa State University Press, 2001, 2nd ed.

TABLE 8.10-Strongylate nematodes in black-tailed or mule deer, Odocoileus hemionus

\begin{tabular}{|c|c|c|}
\hline Location/Species & Locality (State/Province) & Source $^{a}$ \\
\hline \multicolumn{3}{|l|}{ Abomasum } \\
\hline Haemonchus contortus & $\mathrm{BC}, \mathrm{CA}, \mathrm{MT}, \mathrm{SD}, \mathrm{TX}$ & $1,4,6,7,9,14$ \\
\hline Marshallagia marshalli/M. occidentalis & WY & 1,5 \\
\hline Ostertagia bisonis & MT, SD, WY & $1,4,8,12,14$ \\
\hline O. leptospicularis/O. kolchida & OR & \\
\hline O. ostertagi & MT, SD, WY & $1,4,14$ \\
\hline Ostertagia sp. & OR & 14 \\
\hline Pseudostertagia bullosa & MT & 4,14 \\
\hline $\begin{array}{l}\text { Teladorsagia circumcinctal } \\
\quad T . \text { trifurcata }\end{array}$ & $\mathrm{AK}, \mathrm{BC}, \mathrm{CA}, \mathrm{OR}, \mathrm{WY}, \mathrm{UT}$ & $1,2,7,13,14$ \\
\hline $\begin{array}{l}\text { T. davtiani } \\
\text { Trichostrongylus axei }\end{array}$ & CA, MT, OR & $1,7,14$ \\
\hline \multicolumn{3}{|l|}{ Small Intestine } \\
\hline Cooperia oncophora & AZ, MT & $1,4,10$ \\
\hline C. surnabada & CA & \\
\hline Nematodirella antilocaprae & WY & 14,15 \\
\hline N. longissimespiculata & $\mathrm{BC}$ & 1 \\
\hline Nematodirus abnormalis & CA, WY & 1 \\
\hline N. filicollis & $\mathrm{BC}, \mathrm{CA}$ & 1 \\
\hline N. helvetianus & WY & 14 \\
\hline N. odocoilei & $\mathrm{BC}, \mathrm{CA}, \mathrm{MT}, \mathrm{OR}, \mathrm{WY}$ & $1,4,11,14$ \\
\hline N. spathiger & CA, WY & 1,7 \\
\hline Trichostrongylus colubriformis & CA, WY, MT & $1,4,7$ \\
\hline T. longispicularis & MT & 4 \\
\hline T. vitrinus & $\mathrm{CA}$ & 1,7 \\
\hline Trichostrongylus sp. & $\mathrm{BC}, \mathrm{CA}$ & 1 \\
\hline \multicolumn{3}{|l|}{ Large Intestine } \\
\hline Chabertia ovina & $\mathrm{CA}, \mathrm{OR}$ & 1,7 \\
\hline Oesophagostomum venulosum & $\mathrm{AK}, \mathrm{BC}, \mathrm{CA}, \mathrm{OR}$ & $1,7,14$ \\
\hline Oesophagostomum sp. & $\mathrm{AK}$ & 2 \\
\hline
\end{tabular}

${ }^{3}$ 1. Walker and Becklund (1970). 2. C. A. Nielsen, unpublished records, Kodiak Island and Sitka. 3. Hoberg et al. (1993b). 4. Worley and Eustace (1972). 5. Bergstrom (1975a). 6. Stubblefield et al. (1987). 7. Longhurst and Douglas (1953). 8. Worley and Sharman (1966). 9. Gray et al. (1978). 10. Allen and Erling (1964). 11. Becklund and Walker (1967a). 12. Becklund and Walker (1967b). 13. Jensen et al. (1982). 14. Unpublished records, U.S. National Parasite Collection. 15. Lichtenfels and Pilitt (1983b). ${ }^{6}$ Records of $T$, circumcincta require confirmation (Hoberg et al. 1999).

acutum Molin, 1861; O. inflatum var. ovis Carità, 1887; O. vigentimembrum Canavan, 1931.]

Four species of nodular worms are known from the large intestine in wild bovids or cervids from North America. Oesophagostomum venulosum and $O$. cervi are the most commonly occurring species reported in cervids; $O$. columbianum and $O$. radiatum have rarely been reported from wild ruminants. Wild cervids, particularly elk and deer, are the probable source of $O$. venulosum reported in cattle from the western United States (e.g., Baker and Fisk 1986; Hoberg et al. 1988). Wild cervids and bovids, however, are unlikely to be important in the epizootiology of other species, which circulate primarily among domestic hosts.

Diagnosis is based on the examination of adult nematodes. Important characters include the structure of the leaf crowns, relative degree of development of the cephalic vesicle, placement of the cervical papillae, and specific attributes of the copulatory bursa and spicules (e.g., Levine 1980).

Adult nodular worms reside in the lumen of the large intestine, and larvae are found in walls of the small and large intestine, where development of typical nodules may occur. The life cycle for species of Oesophagosto- mum is direct and with respect to free-living larval stages is largely identical to those documented for other strongyloid nematodes (e.g., Levine 1980); L,'s are infective. In contrast to other strongyles, fourthstage larvae develop within nodules in the small and large intestine, and near 17-22 days postinfection, they migrate back to the large intestine for the final molt; the prepatent period is $32-42$ days.

Disease attributable to $O$. venulosum or other species has not been documented for infections in wild ruminants (e.g., Prestwood and Pursglove 1981). This may reflect generally moderate levels of prevalence and low intensity as documented in deer from Florida (27\%-60\%; 1-9 per host) (Forrester 1992). Oesophagostomiosis in domestic hosts, however, is associated with inflammation and the development of characteristic nodules in the intestinal wall. Severe infections in cattle are typified by edema of the intestinal wall, anorexia, weight loss, and diarrhea. Pathogenesis is linked to the level of exposure, with 20,000-250,000 larvae being required to elicit clinical signs (Levine 1980). Consequently, in the relatively sporadic and low intensity infections in deer and other wild ruminants (e.g., Prestwood and Pursglove 1981; Forrester 1992), the probability of significant disease is rare. 
TABLE 8.11-Strongylate nematodes in white-tailed deer, Odocoileus virginianus

\begin{tabular}{|c|c|c|}
\hline Location/Species & Locality (State/ Province) & Source $\mathrm{a}^{\mathrm{a}}$ \\
\hline \multicolumn{3}{|l|}{ Abomasum } \\
\hline Haemonchus contortus & $\begin{array}{l}\text { AL, AR, FL, GA, IL, LA, MI, MS, OK, } \\
\text { PA, SC, SD, TN TX, WI, WV }\end{array}$ & $1,4,5,8,11,12,13,21$ \\
\hline H. placei & FL, TX & 4,18 \\
\hline H. similis & $\mathrm{FL}$ & 1,4 \\
\hline Mazamastrongylus odocoilei & $\begin{array}{l}\text { AL, AR, FL, GA, IL, KY, LA, MA, MD, } \\
\text { ME, MS, NC, NJ, NY, SD, TX, VA, WI }\end{array}$ & $\begin{array}{l}1,3-5,7,9,12,13,15,16 \\
19,21\end{array}$ \\
\hline M. pursglovei & $\mathrm{AL}, \mathrm{AR}, \mathrm{FL}, \mathrm{GA}, \mathrm{KY}, \mathrm{LA}, \mathrm{MS}, \mathrm{NC}, \mathrm{SC}, \mathrm{VA}$ & $3-5,7,16,19$ \\
\hline Obeliscoides cuniculi & $\mathrm{AR}, \mathrm{GA}$ & \\
\hline Ostertagia mossi/ O. dikmansi & $\begin{array}{l}\text { AL, AR, GA, IL, KY, LA, MA, ME, MD, } \\
\text { MS, NC, NJ, NY, OK, ON, PA, SC, TN, } \\
\text { TX, VA, WI, WV }\end{array}$ & $1-3,5,7-9,13,15,16,21$ \\
\hline Ostertagia ostertagi & AR, FL, GA, KY, MA, MS, NY, TX, WV & $1,4,5,12,14,15,20$ \\
\hline Ostertagia sp. & FL, MT, NY, SD, TX & \\
\hline Spiculopteragia spiculoptera & QE & 6 \\
\hline Teladorsagia circumcinctal T. trifurcata & NY & \\
\hline Trichostrongylus askivali & $\begin{array}{l}\text { AL, AR, FL, GA, KY, LA, ME, MS, NC, } \\
\text { OK, SC, TN, TX }\end{array}$ & $4,5,7,15,21$ \\
\hline T. axei & $\begin{array}{l}\mathrm{AL}, \mathrm{AR}, \mathrm{FL}, \mathrm{GA}, \mathrm{KY}, \mathrm{LA}, \mathrm{MD}, \mathrm{ME}, \mathrm{MS} \\
\mathrm{OK}, \mathrm{SC}, \mathrm{TN}, \mathrm{TX}, \mathrm{WI}\end{array}$ & $1,4,5,7,15,21$ \\
\hline T. calcaratus & GA & 5 \\
\hline T. dosteri & FL, GA & 4,5 \\
\hline T. longispicularis & AL, FL, GA, LA, SC, VA, WV & 5 \\
\hline \multicolumn{3}{|l|}{ Small Intestine } \\
\hline Cooperia curticei & KY & 5,20 \\
\hline C. oncophora & $\mathrm{SC}$ & \\
\hline C. pectinata & $\mathrm{TX}$ & 5 \\
\hline C. punctata & AL, FL, GA, LA, MS, SC, TX, VA, WV & 4,5 \\
\hline C. spatulata & $\mathrm{SC}$ & 5 \\
\hline Cooperia sp. & NY, TX & 1,12 \\
\hline Monodontus louisianensis & FL, GA, LA, MS, SC, WV & $1,4,5$ \\
\hline Nematodirus filicollis ${ }^{\mathrm{b}}$ & MI, PA, WI & \\
\hline N. odocoilei & $\begin{array}{l}\mathrm{AL}, \mathrm{AR}, \mathrm{FL}, \mathrm{GA}, \mathrm{KY}, \mathrm{LA}, \mathrm{MA}, \mathrm{MD}, \mathrm{MI}, \\
\text { MS, NC, NY, PA, QE, SC, TX, VA, WA, WI }\end{array}$ & $1,4,5,7,10,21$ \\
\hline Nematodirus sp. & NY, WI & 1 \\
\hline Trichostrongylus sp. & $\mathrm{TX}$ & 1 \\
\hline \multicolumn{3}{|l|}{ Large Intestine } \\
\hline Chabertia ovina & NY & \\
\hline Eucyathostomum webbi ${ }^{\circ}$ & $\mathrm{AR}, \mathrm{FL}, \mathrm{GA}, \mathrm{OK}, \mathrm{SC}$ & $1,4,5,17$ \\
\hline Oesophagostomum cervi ${ }^{\mathrm{d}}$ & $\mathrm{AL}, \mathrm{LA}, \mathrm{MD}, \mathrm{MS}, \mathrm{NC}, \mathrm{VA}, \mathrm{WV}$ & \\
\hline O. columbianum & 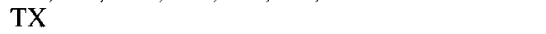 & \\
\hline O. venulosum ${ }^{\mathrm{d}}$ & $\begin{array}{l}\text { AL, FL, GA, KY, LA, MD, MI, MS, NC, NY, } \\
\text { OK, ON, PA, TX, VA, WV }\end{array}$ & $1,4,5,7,8,9,12,20,21$ \\
\hline
\end{tabular}

${ }^{a} 1$. Walker and Becklund (1970). 2. Hoberg et al. (1993b). 3. Lichtenfels et al. (1993). 4. Forrester (1992). 5. Pursglove et al. (1976); Prestwood and Pursglove (1981). 6. Doster and Friend (1971). 7. Davidson et al. (1985). 8. Richardson and Demarais (1992). 9. Davidson and Crow (1983). 10. Foreyt and Trainer (1970). 11. Stubblefied et al. (1987). 12. Waid et al. (1985). 13. Cook et al. (1979). 14. Conti and Howerth (1987). 15. Xiao and Gibbs (1991). 16. Belem et al. (1993). 17. Pursglove (1976). 18. Lichtenfels et al. (1994). 19. Strohlein et al. (1988). 20. Heuer et al. (1975). 21. Foreyt and Samuel (1979).

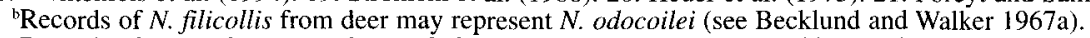

'Records of Eucyathostomum longisubulatum are included under E. webbi, consistent with observation by Pursglove (1976).

${ }^{d}$ Oesophagostumum cervi may represent a synonym of $O$. venulosum (see Baker and Pursglove, 1976), possibly refuting Payne et al. (1967) who provided justification for the validity of the former species. 
TABLE 8.12-Strongylate nematodes in caribou, Rangifer tarandus ${ }^{\mathrm{b}, \mathrm{c}}$

\begin{tabular}{lll}
\hline Location/Species & Locality (State/ Province) & \multicolumn{1}{c}{ Source $^{\mathrm{a}}$} \\
\hline Abomasum & & \\
$\quad$ Marshallagia marshalli & $\mathrm{AK}, \mathrm{NU}$ & 7,8 \\
Ostertagia gruehneri/ O. arctica & $\mathrm{AK}, \mathrm{NF}, \mathrm{NU}, \mathrm{NWT}, \mathrm{ON}$ & $1,2,7,8,12$ \\
O. mossi & $\mathrm{NF}$ & 2 \\
Ostertagia sp. & $\mathrm{AK}, \mathrm{BC}, \mathrm{QE}$ & $3,4,5,9,16$ \\
Teladorsagia boreoarcticus & $\mathrm{NU}$ & 14 \\
Teladorsagia circumcinctaf & & $1,3,4,6,8,9,13,15$ \\
$\quad$ T. trifurcata & $\mathrm{AK}, \mathrm{BC}, \mathrm{NU}, \mathrm{NWT}, \mathrm{QE}$ & 1 \\
Trichostrongylus axei & $\mathrm{NF}$ & \\
Small Intestine & & 9 \\
Nematodirella alcidis & $\mathrm{NWT}$ & $1,2,4,5,9,11$ \\
N. longissimespiculata & $\mathrm{AK}, \mathrm{BC}, \mathrm{NF}, \mathrm{NWT}, \mathrm{ON}, \mathrm{QE}$ \\
Nematodirus filicollis & $\mathrm{NF}$ & 2 \\
N. odocoilei & $\mathrm{NF}$ & 8 \\
N. skrjabini & $\mathrm{AK}$ & $1,5,9,10$ \\
N. tarandi & $\mathrm{AK}, \mathrm{NWT}, \mathrm{QE}$ & 4,16 \\
Nematodirus sp. & $\mathrm{AK}, \mathrm{BC}$ & \\
\hline
\end{tabular}

a1. Fruetel and Lankester (1989) 2. Bergerud (1971). 3. Cowan (1951). 4. Low (1976). 5. Hout and Beaulieau (1984). 6. Jean et al. (1982). 7. E. P. Hoberg, J. Nishi, and S. Kutz unpublished records, near Kugluktuk, NU. 8. C.A. Nielsen, unpublished records. 9. Unpublished records, U.S. National Parasite Collection. 10. Hadwen (1922) in introduced reindeer. 11. Lichtenfels and Pilitt (1983b). 12. Lichtenfels et al. (1990). 13. Becklund (1962). 14. Hoberg et al. (1999). 15. Choquette et al. (1957), in introduced reindeer. 16. Hadwen and Palmer (1922), in introduced reindeer.

'Includes barrenground caribou, Rangifer tarandus groenlandicus; woodland caribou, $R$. t. caribou; Alaskan barrenground caribou, $R$. t. granti; and introduced reindeer from the Palearctic, $R$. $t$. tarandus; records from Peary caribou, $R$. $t$. pearyi, are apparently lacking.

"Additional records from Fruetel and Lankester (1989) include parasites from a captive herd at Kakabeka Falls, Ontario: Ostertagia gruehneri/O. arctica, O. ostertagi, O. leptospicularis/ O. kolchida, Spiculopteragia asymmetrica, S. spiculoptera, Nematodirella longissimespiculata, Nematodirus odocoilei, $N$. helvetianus, Trichostrongylus axei, T. vitrinus, and Oesophagostomum venulosum.

'The report of $O$. mossi from Newfoundland could represent either $O$. gruehneri or $O$. leptospicularis (see Hoberg et al. 1993b; Lichtenfels et al. 1990).

'Specimens of Teladorsagia in barrenground caribou from the central Canadian arctic appear referable to T. boreoarcticus.

The identity of specimens in caribou and reindeer from North America and across the Holarctic requires reevaluation (Hoberg et al. 1999).

${ }^{\mathrm{NU}}=$ Nunavut, Canada, a former region of the eastern Northwest Territories.

TABLE 8.13-Strongylate nematodes in introduced and exotic Cervidae

\begin{tabular}{|c|c|c|c|}
\hline Host Species & Parasite & Locality (State/Province) & Source $^{\mathrm{a}}$ \\
\hline \multirow[t]{2}{*}{ Cervus elaphus } & Spiculopteragia spiculoptera & TX & 1 \\
\hline & S. asymmetrica & TX & 1 \\
\hline \multirow[t]{2}{*}{ Cervus nippon } & None reported & MD, VA & 7 \\
\hline & Oesophagostomum venulosum & TX & 8 \\
\hline \multirow[t]{8}{*}{ Cervus dama } & Cooperia punctata & $\mathrm{AL}$ & 5 \\
\hline & Haemonchus contortus & $\mathrm{AL}, \mathrm{TX}$ & 5,8 \\
\hline & Mazamastrongylus odocoilei & $\mathrm{AL}, \mathrm{KY}$ & 2,5 \\
\hline & M. pursglovei & KY & 2 \\
\hline & Nematodirus odocoilei & $\mathrm{KY}$ & 2 \\
\hline & Oesophagostomum venulosum & $\mathrm{KY}, \mathrm{TX}$ & 2,8 \\
\hline & Ostertagia mossi & $\mathrm{KY}$ & 4 \\
\hline & Spiculopteragia asymmetrica & GA, KY & 2,3 \\
\hline Cervus unicolor & Trichostrongylus askivali & FL & 6 \\
\hline \multirow{4}{*}{ Axis axis } & Haemonchus contortus & TX, HI & 8,9 \\
\hline & Cooperia punctata & $\mathrm{HI}$ & 9 \\
\hline & Oesophagostomum venulosum & TX & 8 \\
\hline & Trichostrongylus axei & $\mathrm{HI}$ & 9 \\
\hline Elaphurus davidianus & Spiculopteragia suppereri & TX & 10 \\
\hline
\end{tabular}

Nematodes with potential for introduction in cervids:

Ashworthius sidemi Schul'ts, 1933-Palearctic

Schulzinema spp. Krastin, 1937-Asia

Spiculopteragia spp.-Palearctic

1. Rickard et al. (1993). 2. Davidson et al (1985) 3. Doster and Friend (1971) 4. Phillips et al (1974) 5. Brugh (1971) 6. Davidson et al. (1987). 7. Davidson and Crow (1983). 8. Richardson and Demarais (1992). 9. McKenzie and Davidson (1989).

10. T. M. Craig and J. H. Johnson, unpublished record (Abstract No. 61, Southern Conference on Animal Parasites, Louisiana State University, Baton Rouge, 1994). 
TABLE 8.14-Strongylate nematodes in introduced and exotic Bovidae and Camelidae

\begin{tabular}{|c|c|c|c|}
\hline Host Species & Parasite & Locality (State/Province) & Source \\
\hline \multicolumn{4}{|l|}{ Bovidae: } \\
\hline \multirow[t]{2}{*}{ Addax nasomaculatus } & Haemonchus contortus & TX & 1 \\
\hline & Longistrongylus curvispiculum & $\mathrm{TX}$ & 1 \\
\hline \multirow[t]{7}{*}{ Antilope cervicaprae } & Camelostrongylus mentulatus & $\mathrm{TX}$ & 2 \\
\hline & H. contortus & TX & 2 \\
\hline & Nematodirus spathiger & $\mathrm{TX}$ & 2 \\
\hline & Oesophagostomum sp. & $\mathrm{TX}$ & 2 \\
\hline & Trichostrongylus axei & $\mathrm{TX}$ & 2 \\
\hline & T. colubriformis & TX & 2 \\
\hline & T. probolurus & $\mathrm{TX}$ & 2 \\
\hline \multirow[t]{2}{*}{ Hippotragus niger } & H. contortus & TX & 1 \\
\hline & L. curvispiculum & $\mathrm{TX}$ & 1 \\
\hline \multirow[t]{2}{*}{ Oryx beisa } & H. contortus & $\mathrm{TX}$ & 1 \\
\hline & L. curvispiculum & $\mathrm{TX}$ & 1 \\
\hline \multicolumn{4}{|l|}{ Camelidae: } \\
\hline \multirow[t]{12}{*}{ Llama glama } & Camelostrongylus mentulatus & OR & 3 \\
\hline & Cooperia oncophora & OR & 3 \\
\hline & C. surnabada & OR & 3 \\
\hline & Haemonchus sp. & OR & 3 \\
\hline & Nematodirus filicollis & OR & 3 \\
\hline & N. helvetianus & OR & 3 \\
\hline & N. spathiger & OR & 3 \\
\hline & Ostertagia ostertagi & OR & 3 \\
\hline & Oesophagostomum venulosum & OR & 3 \\
\hline & T. axei & OR & 3 \\
\hline & T. longispicularis & OR & 3 \\
\hline & T. vitrinus & OR & 3 \\
\hline \multirow{2}{*}{\multicolumn{4}{|c|}{ Nematodes with potential for introduction in bovids and camelids: }} \\
\hline & & & \\
\hline \multicolumn{4}{|c|}{ Cooperiinae, genera and species-Africa; bovids } \\
\hline \multicolumn{4}{|c|}{ Haemonchus spp.-Africa; bovids } \\
\hline \multicolumn{4}{|c|}{ Lamanema chavezi Becklund, $1963-\mathrm{S}$. America; camelids } \\
\hline \multicolumn{4}{|c|}{ Longistrongylus spp.-Africa; bovids } \\
\hline \multicolumn{4}{|c|}{ Mecistocirrus digitatus (Linstow, 1906)-S. America, Central America, Asia; bovids } \\
\hline Sarwaria bubalis (Sar & India, S. America; bovids & & \\
\hline
\end{tabular}

1. Craig (1993). 2. Thornton et al. (1973a, 1973b). 3. Rickard and Bishop (1991).

\section{Genus Cooperia Ransom, 1907}

Classification: Trichostrongyloidea:

Trichostrongylidae: Cooperiinae.

Common Name: Cooperias.

Cooperia oncophora (Railliet, 1898). [Synonyms: Strongylus radiatus Rudolphi, 1803 in part; $S$. ventricosus Rudolphi, 1809 in part; S. oncophorus Railliet, 1898; C. bisonis Cram, 1925.]

Cooperia curticei (Railliet, 1893). [Synonyms: Strongylus ventricosus Rudolphi, 1809; S. curticei Giles, 1892; S. curticei Railliet, 1893.]

Cooperia punctata (Linstow, 1897). [Synonyms: Strongylus sp. Schneider, 1906; S. punctatus Linstow, 1896 in Schneider, 1907; S. bovis Vrijburg, 1907; C. brasiliensis Travassos, 1914.]

Cooperia pectinata (Ransom, 1907). [Synonym: $C$. nicoli Baylis, 1929.]

Cooperia spatulata (Baylis, 1938).

Cooperia surnabada (Antipin, 1931). [Synonym: $C$. mcmasteri Gordon, 1932.]

Species of Cooperia are well defined morphologically and can be identified based on the structure of the spicules and copulatory bursa in males and by the synlophe (the system of cuticular ridges characteristic of most trichostrongylids) in males and females (Lichtenfels 1977; Gibbons and Khalil 1982; Durette-Desset 1983). There are six species known from North America, although there is compelling evidence based on biochemical and nucleotide data that $C$. surnabada is a morphological form of $C$. oncophora (see Isenstein 1971; Humbert and Cabaret 1995).

Consistent with other trichostrongylids, the life cycle is direct; adults reside in the small intestine. The prepatent period may be 17-22 days (Levine 1980). Species are primarily parasites of sheep and cattle, but are relatively minor parasites in sylvatic bovids and cervids. All species known from domesticated hosts have been found in wild ruminants, the most commonly reported being $C$. oncophora. Particularly in sylvatic bovids, species of Cooperia are usually found in association with other trichostrongyles acquired on common range with cattle or sheep. Most records show that intensity and prevalence are minimal in wild hosts, and these nematodes are unlikely to occur at levels considered pathogenic. In contrast, heavy infections in calves may lead to serious disease 
TABLE 8.15-Number of adult nematodes needed to produce clinical signs in calves less than one year in age: monospecific infections ${ }^{\mathrm{a}}$

\begin{tabular}{lll}
\hline Parasite & Morbidity & \multicolumn{1}{c}{ Mortality } \\
\hline Cooperia spp. & 140,000 & $?$ \\
Haemonchus spp. & $5,000-9,000$ & $>10,000$ \\
Ostertagia ostertagi & $5,000-15,000$ & $12,000-15,000$ \\
& (Type II) & (Type II) \\
Nematodirus spp. & $600-13,000$ & $?$ \\
Trichostrongylus spp. & 100,000 & $>140,000$ \\
\hline
\end{tabular}

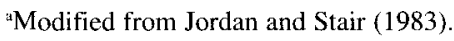

(Levine 1980) (Tables 8.15 and 8.16). Geographically, climatological factors may limit the distribution of Cooperia spp. to the southern temperate and boreal zones as they have only rarely been recognized among sylvatic hosts at higher latitudes of the subarctic and arctic regions.

Genus Haemonchus Cobb, 1898

Classification: Trichostrongyloidea:

Trichostrongylidae: Haemonchinae.

Common Name: Large stomach worms; barber pole worms.

Haemonchus contortus (Rudolphi, 1803). [Synonyms: $H$. bispinosus Molin, 1860; H. lunatus Travassos, 1914; H. cervinus Baylis and Daubney, 1922; $H$. atectus Lebedev, 1929; H. pseudocontortus Lebedev, 1929; H. fuhrmanni Kamensky, 1929; H okapiae van den Berghe, 1937 in part; H. tartaricus Evranova, $1940 ; H$. contortus contortus Das and Whitlock, 1960; H. contortus cayugensis Das and Whitlock, 1960; H. contortus bangelorensis Rao and Rahman, $1967 ; H$. contortus hispanicus Martínez and Gómez, 1968; H. contortus kentuckiensis Sukhapesna, 1974; and H. contortus var. uktalensis Das and Whitlock, 1960.]

Haemonchus placei (Place, 1893).

Haemonchus similis Travassos, 1914. [Synonym: $H$. bubalis Chauhan and Pande, 1968.]

Haemonchines that could be introduced: Ashworthius sidemi Schulz, 1933 is a species that could be introduced with Palearctic cervids such as red deer.

Species of Haemonchus are parasites of the abomasum and are broadly distributed nematodes in rumi- nants throughout the world. Among the ten currently valid species, three have been documented in wild bovids or cervids from North America; all are typical parasites of either domestic sheep or cattle (see Lichtenfels et al. 1994). Considering these, $H$. contortus has been widely reported from both bovid and cervid hosts across the boreal and southern regions of North America (Levine 1980; Prestwood and Pursglove 1981; Forrester 1992); records of $H$. place $i$ and $H$. similis apparently are rare.

Nematodes of this genus are characterized by a prominent buccal tooth, well-developed synlophe, and copulatory bursa in the male. Identification to species, until recently somewhat equivocal, is now based on structural characteristics of adult worms, particularly the configuration of the synlophe in the cervical region of males and females, the length of the spicules in males [see Lichtenfels et al. (1994) for review], and differences in the ITS region of rDNA (Zarlenga et al. 1994). This has eliminated the controversy over the validity of $H$. place $i$, which has often been listed as a synonym of $H$. contortus (e.g., Gibbons 1979). A potential problem is now evident, however, with respect to records of $H$. contortus and $H$. place $i$ from wild hosts in the United States and Canada. Prior to the studies by Lichtenfels et al. (1994) it was not possible to unambiguously distinguish between $H$. place $i$ and $H$. contortus based on morphological characters. Thus, although the latter is the most commonly reported species in deer, bison, pronghorn, bighorn sheep, and exotic cervids, the records must be considered suspect and may not reflect accurate identifications. Additionally, the contention that Haemonchus represents an "actively evolving" group in the sense presented by Das and Whitlock (1960) and Prestwood and Pursglove (1981) is no longer supportable. This concept for $H$. contortus had been based on the premise of a number of diagnosable subspecies (Das and Whitlock 1960) defined by morphological characters that have since been found to be influenced by broad intraspecific variation (Gibbons 1979).

The life cycle for species of Haemonchus is direct, with blood-feeding adults producing eggs that are shed in the feces. Infective $L_{3}$ 's develop in $\sim 3$ days under optimum conditions. Following ingestion by the ruminant host, development to the fourth stage is completed in 48 hours. Larvae, situated at the surface of the

TABLE 8.16 Number of adult nematodes needed to produce clinical signs in calves less than one year in age: multispecies infections ${ }^{\mathrm{a}}$

\begin{tabular}{lclcr}
\hline Parasite & Intensity & \multicolumn{1}{c}{ Other Parasites and Intensity } & Outcome \\
\hline Cooperia & $6000-25,000$ & Ostertagia & $2000-10,000$ & Morbidity \\
& & Nematodirus & $300-1000$ & \\
Trichostrongylus & $10,000-65,000$ & Trichostrongylus & $200-20,000$ & Morbidity \\
Trichostrongylus & $20,000-50,000$ & Ostertagia & $12,000-20,000$ & Morbidity \\
& & Cooperia & $12,000-20,000$ & $20,000-40,000$ \\
\hline
\end{tabular}

${ }^{a}$ Mod: fied from Jordan and Stair (1983). 
Hoberg, Kocan \& Rickard in Parasitic Diseases of Wild Mammals (Samuel, Pybus \& Kocan. eds.). lowa State University Press, 2001, 2nd ed.

mucosa, feed on blood and complete development to the adult stage; the prepatent period is $\sim 18-21$ days (Levine 1980).

Species of Haemonchus, but particularly those identified as $H$. contortus, are widely distributed in North America and have been reported from bovids (Bison bison, Ovis canadensis), cervids (Odocoileus spp.; and exotic species), and Antilocapra americana in a range extending north to British Columbia and Alberta. When found in white-tailed deer it is most common in the southeastern United States (Prestwood and Pursglove 1981). Species of Haemonchus are not known from the subarctic and arctic regions, a pattern similar to that known for Cooperia spp.

Data for prevalence and intensity of Haemonchus suggest that among wild ruminants these are relatively uncommon parasites except in deer and pronghorn. Haemonchus contortus was the most commonly occurring nematode reported by Boddicker and Hugghins (1969) in A. americana examined in South Dakota ( $68 \%$ of 60 animals). With respect to other recorded hosts, prevalence and intensity have been relatively minimal except in Odocoileus spp., and in deer appear to vary geographically. The highest levels of infection by $H$. contortus in white-tailed deer have been observed in the sandy, coastal plain localities of the southeastern United States (Prestwood and Pursglove 1981). In this region prevalence approached $100 \%$, and the maximum intensity documented exceeded 4300 worms (Pursglove et al. 1976; Prestwood and Pursglove 1981). Forrester (1992) summarized records from Florida, where overall prevalence in fawns was near $100 \%$ (with up to 10,545 worms) and in adults near $80 \%$ (maximum 2083 worms). Morbidity and direct mortality in deer, particularly fawns, has been attributed to infections ranging from over 1000 nematodes to a maximum of 16,540 , the former possibly synergistic with malnutrition and the presence of other parasites (Prestwood and Kellogg 1971; Davidson et al. 1980; Forrester 1992).

Based on reports from white-tailed deer, species of Haemonchus must be considered as recognized and potential primary pathogens in wild ruminants (Davidson et al. 1980; Prestwood and Pursglove 1981; Forrester 1992). Boddicker and Hugghins (1969) reported hemorrhagic lesions when $H$. contortus, along with other trichostrongyles, were present in large numbers in pronghorn. In deer, and presumably other wild ruminants, haemonchosis is associated with severe blood loss (Foreyt and Trainer 1970). Typical clinical signs include stunting and emaciation, pale mucous membranes, and "bottle jaw" with the accumulation of fluid in the submandibular region. Internally, tissues and organs are pale, and ascitic fluid is commonly found in the body cavity. The mucosa of the abomasum is reddened, ulcerated, and eroded, and large numbers of nematodes may be visible (Prestwood and Pursglove 1981).

Although clearly pathogenic, diagnosis is problematic as the clinical signs of infection may develop prior to patency, and the eggs of Haemonchus cannot be reliably distinguished from those of related trichostrongylids using traditional methods (Georgi and McCulloch 1989; Sommer 1996). Clinical signs, particularly anemia, in conjunction with animals originating in areas where Haemonchus may be enzootic, continue to be among the most useful criteria for diagnosis (Prestwood and Pursglove 1981). With the advent of molecular markers for Haemonchus and other genera of trichostrongylids, it should now be possible to unequivocally identify eggs in feces (Zarlenga et al. 1994; Lichtenfels et al. 1997), thus replacing the laborious task of distinguishing among $\mathrm{L}_{3}$ 's recovered from fecal cultures. As outlined above, adult males and females of the three species known from North America can now be reliably identified based on morphological and molecular criteria (Lichtenfels et al. 1994).

Currently, control and treatment remain problematic. An array of efficacious anthelmintics, including benzimidazoles and avermectins, with significant activity against adults and larvae of Haemonchus and other trichostrongyles are available; however, few have "label approval" for applications in wild bovids or cervids (e.g., "Safe-Guard" a formulation of fenbendazole released by Hoechst-Roussel is listed for use in zoo and wild animals as a broad spectrum nematocide). Accordingly, effective dosages, routes of administration, potential toxicity, side effects, and predictable efficacies generally have not been determined for most wild ruminants. The difficulties are compounded by the problems of attempting anthelmintic therapy in freeranging ruminants (Prestwood and Pursglove 1981), which indeed may only be practical when dealing with confined or endangered species. The use of anthelmintics in game animals is further complicated by the "withdrawal" periods that would be required for some compounds. Management practices that limit competition with other ruminants and overpopulation on areas used for foraging appear to be most appropriate to control and limit the impact of haemonchosis (Prestwood and Pursglove 1981).

\section{Genus Pseudostertagia Orloff, 1933}

Classification: Trichostrongyloidea:

Trichostrongylidae: Libyostrongylinae.

Pseudostertagia bullosa (Ransom and Hall, 1912).

[Synonyms: Ostertagia bullosa Ransom and Hall,

1912; Ostertagia (Pseudostertagia) bullosa Orloff, 1933.]

Originally described in the genus Ostertagia, this nematode was later transferred to the Libyostrongylinae and is currently the only member of the subfamily known as a typical parasite in ruminants from North America (Durette-Desset and Chabaud 1977). Unlike most members of the Libyostrongylinae, the synlophe is well developed (Durette-Desset 1983). Pseudostertagia bullosa was originally described from domestic sheep in Colorado (Ransom and Hall 1912). This is primarily a parasite of the abomasum in A. americana 
from western North America and is seldom observed in $O$. hemionus and $O$. canadensis. There have been subsequent records from domestic sheep in this region, but none from cattle (Becklund 1964). It has been suggested that the occurrence of this nematode in domestic stock is dependent on the presence of pronghorn (Lucker and Dikmans 1945). Morbidity and mortality in wild or domestic ruminants has not been observed.

\section{Genus Obeliscoides Graybill, 1924}

Classification: Trichostrongyloidea:

Trichostrongylidae: Libyostrongylinae.

Obeliscoides cuniculi (Graybill, 1923). [Synonym:

Obeliscus cuniculi Graybill 1923.]

Lagomorphs, particularly Lepus spp. and Sylvilagus spp., are the characteristic hosts for $O$. cuniculi in North America. There are only two reports of this species in the abomasum of white-tailed deer, and as a consequence this is considered an atypical parasite in white-tailed deer (Maples and Jordan 1966; Prestwood and Pursglove 1981). It was also found in O. canadensis transported from Colorado to North Dakota (unpublished records, U.S. National Parasite Collection).

Subfamily Ostertagiinae

Classification: Trichostrongyloidea:

Trichostrongylidae.

Common Name: Medium stomach worms.

The ostertagiines, or medium stomach worms, are among the most pathogenic of the strongyles known from ruminants (Levine 1980). In North America and across the Holarctic region, nematodes of this subfamily parasitize both cervids and bovids and represent a dominant component of the abomasal nematode fauna (Drózdz 1965, 1966; Govorka et al. 1988; Lichtenfels and Hoberg 1993). Taxonomy and systematics among the ostertagiine nematodes have been particularly confused and are still open to resolution with respect to nomenclature and relationships at the generic and species level (e.g., Drózdz 1965, 1995; Gibbons and Khalil 1982; Durette-Desset 1982, 1983; Lichtenfels and Hoberg 1993; Hoberg et al. 1993a,b; Hoberg 1996). A considerable divergence in opinion exists over the number of genera in the Ostertagiinae. Gibbons and Khalil (1982) recognized 17 genera, Durette-Desset (1982, 1983) included 5 or 6 genera, Jansen (1989) proposed 7 genera, and most recently Drózdz (1995) presented arguments for inclusion of 9 genera in the subfamily. The diversity of opinions for generic level taxonomy relates in part to rejection or acceptance of the hypothesis for polymorphism among male nematodes in this group (Lichtenfels and Hoberg 1993; Lichtenfels et al. 1997). Lack of resolution over the generic-level taxonomy and systematics is not a trivial issue as it directly impacts our abilities to formulate any comprehensive understanding of parasite-host biology.

A key in addressing the generic limits within the ostertagiine subfamily is recognition of polymorphism, arguably the most important concept related to taxonomy in this group over the past 20 years (Drózdz 1974; Daskalov 1974; Lancaster and Hong 1981; Lancaster et al. 1983). The polymorphism hypothesis was based on the following observations: (1) pairs of male morphotypes consistently occur together, with one constituting a "major" proportion and the other a "minor" proportion of the combined population; and (2) consistent structural differences allow recognition of each of the morphological types. In the past this led to the recognition of separate genera and species for major and minor morphotypes (e.g., Drózdz 1965; Gibbons and Khalil 1982). These are now regarded as a series of polymorphic species distributed among a reduced number of genera (Drózdz 1995). The proposal for polymorphism has been corroborated based on morphological, biochemical, and molecular grounds (for review see Lichtenfels and Hoberg 1993; Lichtenfels et al. 1997). Consistent with the hypothesis for polymorphism in males, the number of valid genera probably will not exceed nine (see Drózdz 1995), but definitive resolution is dependent on phylogenetic studies of this group now in progress (Hoberg et al. 1993a; Hoberg and Lichtenfels 1994).

In North American ruminants, species of seven genera have been recognized. The endemic fauna in wild bovids and cervids includes species of Ostertagia (containing Orloffia in this review), Teladorsagia, Marshallagia, and Mazamastrongylus. Species of Spiculopteragia, Camelostrongylus, and Longistrongylus have been introduced coincidental with importation of exotic bovids and cervids from the Palearctic, SubSaharan Africa, and possibly South America (Tables 8.13 and 8.14) (Lichtenfels and Hoberg 1993; Lichtenfels et al. 1997). Among these, polymorphism has been recognized in Ostertagia, Marshallagia, Teladorsagia, and Spiculopteragia, whereas it is considered to be absent in Mazamastrongylus, Camelostrongylus, and Longistrongylus (Drózdz 1995). Keys for the identification of genera and species in North American ruminants are presented in Lichtenfels et al. (1988a,b) and Lichtenfels and Hoberg (1993). It should be noted that nomenclature for the genera and species of ostertagiines as proposed by Durette-Desset (1989) is inconsistent with the hypothesis for polymorphism (see Lichtenfels and Hoberg 1993; Drózdz 1995).

Medium stomach worms are characterized by a reduced buccal capsule and well-developed copulatory bursa in the male. The cervical papillae are prominent and thorn-like. The synlophe is composed of a large number of cuticular ridges that are perpendicular to the body surface; in the cervical region one of three patterns, consistent with either generic- or species-level groups can be recognized (Lichtenfels and Hoberg 1993). The genital cone always has paired "0" papillae ventrally, and an accessory bursal membrane containing the paired "7" papillae dorsally. The lateral rays of the copulatory bursa are in a pattern of $2-1-2$ or $2-2-1$, considered characteristic for specific generic groups (Durette-Desset 1982, 1983). 
Identification of medium stomach worms is based on the structure of the bursa, genital cone, and spicules in males and on the dimensions of the esophageal valve and the configuration of the synlophe in males and females. Application of the synlophe has allowed accurate identification of females of most species for the first time (Lichtenfels et al. 1988a,b; Lancaster and Hong 1990). The identification of infective and parasitic larval stages continues to remain problematic (e.g., Belem et al. 1993) but is vital for developing an understanding of epizootiological patterns such as arrested development. It continues to be difficult to reliably identify eggs of any ostertagiines other than Marshallagia, and diagnosis of infection is still linked to necropsy, recovery, and identification. Quantification is best achieved by the application of an aliquot method such as that outlined in Prestwood and Pursglove (1981).

The life cycles for medium stomach worms found in sylvatic ruminants in North America are direct, but specific details of larval development and adult longevity are undetermined (for data from the Palearctic see Semenova and Korosteleva 1980; Semenova 1987; Govorka et al. 1988). Patterns of development of freeliving and parasitic stages should parallel those elucidated for congeners in domestic bovids (Levine 1963; Herd 1986). Adults reside in the abomasum, embryonated eggs are passed in feces, and the first through third larval stages are free-living. The infective third stage is ensheathed, and parasitic development and the prepatent period require between 2 and 3 weeks, depending on the species involved. The potential for arrested development in response to seasonal and perhaps other factors (e.g., parasite density or immune status of host) may substantially prolong developmen time in the definitive host (but see Halvorsen 1986). In these instances, early fourth-stage larvae are retained in the abomasal mucosa for extended periods of time prior to resuming maturation to the adult stage. Evidence for seasonally defined inhibition (e.g., a summer or winter pattern) in wild hosts has been limited primarily to data from deer, some being equivocal or problematic to interpret (Baker and Andersen 1975; Conti and Howerth 1987; Borgsteede 1988; Xiao and Gibbs 1991; Belem et al. 1993). Also, life history patterns for species of $\mathrm{Mar}$ shallagia, Ostertagia, and Teladorsagia in the Arctic may be adapted to high-latitude environments and, thus, differ from those observed in the mid-latitude boreal zones (Halvorsen and Bye 1999; Halvorsen et al. 1999; Irvine et al. 2000).

In general, specific morbidity and mortality has not been linked to the ostertagiines that parasitize wild ruminants. Data for prevalence and intensity of infection, however, have been difficult to document. It is probable that "subclinical" effects (e.g., alteration of foraging behavior, host physiology, and body weight) may be recognized that are similar to those documented for the influence of ostertagiines in domestic hosts. In particular, modification of food intake and body weight can be linked directly to prasitism by abo- masal nematodes (e.g., Arneberg et al. 1996; Arneberg and Folstad 1999). Clinical signs of ostertagiosis in cattle are characterized by anemia, emaciation, submandibular edema, and diarrhea. In such cases, in excess of 40,000 nematodes may be present in the abomasum, and a minimum of 10,000 is considered necessary for development of severe gastric disease (Tables 8.15 and 8.16) (Levine 1980). In contrast, intensities of infection in Odocoileus spp. rarely exceed several hundred, with a maximum near 4000 for Ostertagia spp. (e.g., Prestwood and Pursglove 1981; Waid et al. 1985; Conti and Howerth 1987; Belem et al. 1993). Similar low intensities occur in $R$. tarandus (hundreds to several thousand for Ostertagia and Teladorsagia) (e.g., Bye 1987; Arneberg et al. 1996) and other cervids and bovids. In sylvatic hosts, environmental factors may result in fewer parasites being required to produce disease than in domestic stock (Pursglove et al. 1976). A confounding factor in understanding the distribution and potential for disease is the paucity of epizootiological information on patterns of transmission and the occurrence of Type I and Type II ostertagiasis in wild hosts (e.g., Gibbs and Herd 1986; Conti and Howerth 1987; Connan 1991, 1996).

Manifestations of ostertagiasis in deer have been associated with infections in excess of 1000 nematodes. In these instances, edema and pin-point ulcerations of the abomasal mucosa may be observed, which in heavier infections may coincide with nodular thickening of the abomasal mucosa (e.g., Conti and Howerth 1987). Generally, lesions are not evident in hosts with lower numbers of ostertagiines (Prestwood and Pursglove 1981).

Control of these and other nematodes in cervids has received some attention, particularly due to the commercial aspects of game ranching in New Zealand, North America, and the United Kingdom. Benzimidazoles and avermectins have been shown to be efficacious against ostertagiines and other gastrointestinal strongyles in red deer, and some recommendations for dosages have been outlined (e.g., MacKintosh et al. 1985; Kutzer 1987; Andrews and Lancaster 1988; Connan 1996). Pharmicokinetics, however, remains poorly understood (e.g., Lancaster and Andrews 1991). As indicated above, for Haemonchus spp., application of anthelmintics continues to be problematic, and label approval is generally lacking for helminths in wild ruminants.

Specific aspects of the biology and host and geographic distribution of ostertagiines in North America are addressed below. It should be noted that most genera and species have somewhat specific distributions linked to either cervids or bovids; the occurrence of some ostertagiines is associated with importation of exotic ruminants.

\section{Genus Marshallagia Orloff, 1933}

Classification: Trichostrongyloidea:

Trichostrongylidae: Ostertagiinae.

Marshallagia marshalli (Ransom, 1907) Orloff, 1933/M. occidentalis (Ransom, 1907) Durette- 
Desset, 1982. [Synonyms of M. marshalli: Ostertagia marshalli (Ransom, 1907) Orloff, 1933; O. brignatiaca Blanchard, 1909; O. tricuspis Marotel, 1912; Haemonchus sp. Marshall, 1904; O. orientalis Bhalero, 1932.] [Synonyms of $M$. occidentalis: Grosspiculagia occidentalis of Jansen, 1958; Ostertagiella occidentalis (Ransom, 1907)

Andreeva, 1957; Grosspiculagia trifida (Cuillé, Marotel, and Panisset, 1912) Sarwar, 1956;

Grosspiculagia skrjabini (Kamenskii, 1929)

Sarwar, 1956.]

Marshallagia marshalli/M. occidentalis represent a single polymorphic species, the only member of this genus currently recognized in North America (Lichtenfels and Pilitt 1989). Specimens designated as Marshallagia sp./Ostertagia sp. in mountain goat from western North America may represent a distinct species, but confirmation will require comparison to congeners known from Eurasia (Lichtenfels and Pilitt 1989). Additionally, Drózdz (1995) considers Marshallagia sp. in bighorn sheep to represent a species distinct from $M$. marshalli.

Pending resolution of the taxonomy for Marshallagia spp. in the Nearctic, $M$. marshalli has a broad host distribution in bovids and cervids extending from the northwestern regions into the Arctic. In Wyoming it was found to be a common parasite in bighorn sheep (67\%-80\% prevalence based on fecal examination and necropsy, respectively) and pronghorn $(36 \%-47 \%)$, but rare or absent in moose, elk, and mule deer (Bergstrom 1975a). In the Northwest Territories and Nunavut, Canada, it was found in muskoxen and caribou (Webster and Rowell 1980; E.P. Hoberg et al., unpublished). It is considered a parasite more typical of wild sheep and bovids than of cervids. For example, it was suggested that the presence of $M$. marshalli in reindeer from Spitzbergen was the result of introduction of the parasite with muskoxen (Bye et al. 1987).

Adults of this species can be identified based on the structure of the copulatory bursa and spicules in males and by the synlophe in males and females (Lichtenfels and Pilitt 1989; Lichtenfels and Hoberg 1993). Eggs are recognizable in fecal examination by their large size ( $>150 \mu \mathrm{m}$ in length) and would potentially be confused only with those of Nematodirus spp. or Nematodirella spp.

This is a nearly ubiquitous parasite of bighorn sheep, often with $100 \%$ prevalence at some localities (Becklund and Senger 1967; Uhazy and Holmes 1971; Kistner et al. 1977) (Table 8.5); maximum reported intensity was near 1300 nematodes. Despite relatively high prevalence and intensity in some hosts, there are no specific reports of pathogenicity related to infections of Marshallagia in wild ruminants. In domestic sheep in Eurasia, however, marshallagiasis may result in significant disease (see Bye and Halvorsen 1983). Marshallagia marshalli has been reported from sheep but not cattle in North America. Substantial prevalence (100\%) and intensity (near 11,000 ) have been documented in reindeer from Svalbard, Norway, exceeding that reported from North American caribou (C.A. Nielsen, unpublished). The intensity of infection may be sufficient to adversely influence host productivity and life expectancy (Bye and Halvorsen 1983).

\section{Genus Mazamastrongylus Jansen, 1986}

Classification: Trichostrongyloidea:

Trichostrongylidae: Ostertagiinae.

Mazamastrongylus odocoilei (Dikmans, 1931) Jansen, 1986. [Synonyms: Ostertagia odocoilei Dikmans, 1931; Skrjabinagia odocoilei (Dikmans, 1931) Kassimov, 1942; Ostertagiella odocoilei (Dikmans, 1931) Andreeva, 1956; Spiculopteroides odocoilei (Dikmans, 1931) Jansen, 1958; Apteragia odocoilei (Dikmans, 1931) Drózdz, 1965; Camelostrongylus odocoilei (Dikmans, 1931) Durette-Desset, 1989.]

Mazamstrongylus pursglovei (Davidson and Prestwood, 1979) Jansen, 1986. [Synonyms: Apteragia pursglovei Davidson and Prestwood, 1979; Spiculopteroides pursglovei (Davidson and Prestwood, 1979) Hinaidy and Prosl, 1981; Teladorsagia pursglovei (Davidson and Prestwood, 1979) Durette-Desset, 1989.]

Species of Mazamastrongylus are largely hostspecific parasites in cervids from the Holarctic (Drózdz 1995; Hoberg 1996; Hoberg and Khrustalev 1996). Two species of Mazamastrongylus occur in Odocoileus virginianus from eastern North America (Lichtenfels et al. 1993). The distribution of $M$. odocoilei coincides with that of white-tailed deer, whereas that of $M$. pursglovei is restricted to the southeastern United States, such that the two species have overlapping but distinct geographic ranges (Strohlein et al. 1988; Lichtenfels et al. 1993). Records from other cervid hosts are rare (fallow deer and wapiti) (Tables 8.9 and 8.13), and there are no reports of either species in domestic stock.

Morphologically, species of Mazamastrongylus have a characteristic tapering synlophe and club-shaped esophagus. They can only be confused with species of Spiculopteragia from which they are separated by the structure of the spicules (Lichtenfels et al. 1993; Hoberg 1996). Only two characters, spicule length and structure, are useful in distinguishing between males of $M$. pursglovei and $M$. odocoilei; females cannot be identified.

Mazamastrongylus spp. are the most commonly occurring parasites in white-tailed deer, with $20 \%-100 \%$ prevalence and a maximum of $10-9060$ worms reported at specific localities (Davidson and Prestwood 1979; Prestwood and Pursglove 1981; Forrester 1992); mixed infections are not uncommon. There are no specific reports of pathogenicity associated with infections of either species.

Genus Ostertagia Ransom, 1907 (including Orloffia Drózdz, 1965)

Classification: Trichostrongyloidea:

Trichostrongylidae: Ostertagiinae. 
Hoberg, Kocan \& Rickard in Parasitic Diseases of Wild Mammals (Samuel, Pybus \& Kocan. eds.). lowa State University Press, 2001, 2nd ed.

Ostertagia bisonis Chapin, 1925/O. kazakhstanica (Dikov and Nekipelova, 1963). [Synonyms of $O$. bisonis: Ostertagia orloffi Sankin, 1930; Ostertagia bellae Landrum, 1951 nomen nudum;

Camelostrongylus bisonis (Chapin, 1925) Durette-

Desset, 1989; Orloffia orloffi (Sankin, 1930)

Drózdz, 1995; Orloffia bisonis (Chapin, 1925)

Drózdz, 1995.] [Synonym of O. kazakhstanica: Orloffia sp. of Drózdz, 1995.]

Ostertagia gruehneri Skrjabin, 1929/O. arctica Mitzkewitsch, 1929. [Synonym of $O$. gruehneri: Griihneria grühneri Sarwar, 1956.] [Synonyms of O. arctica: Sjobergia arctica (Mitzkewitsch, 1929) Sarwar, 1956; Ostertagiella arctica (Mitzkewitsch, 1929) Andreeva, 1957; Skrjabinagia arctica (Mitzkewitsch, 1929) Drózdz, 1965.]

Ostertagia leptospicularis Asadov, 1953/O.kolchida Popova, 1937. [Synonyms of O. leptospicularis: Capreolagia skrjabini Shul'ts, Andreeva and Kadenazii, 1954; Ostertagia capreoli Andreeva, 1957; Ostertagia taurica Kadenazii and Andreeva, 1956 nomen nudum; Ostertagia crimensis Kadenazii and Andreeva, 1956 nomen nudum; Capreolagia antipini Kadenazii, 1957; Capreolagia paraskrjabini Kadenazii, 1957; Ostertagia paracapreoli Kadenazii and Andreeva, 1957; Ostertagia capreolagi Jansen, 1958.] [Synonyms of O. kolchida: Ostertagia (Ostertagia) kolchida Popova, 1937; Sjobergia kolchida (Popova, 1937) Sarwar, 1956; Ostertagia (Skrjabinagia) popovi Kassimov, 1942; Skrjabinagia popovi Kassimov, 1942; Grosspiculagia popovi (Kassimov, 1942) Jansen, 1958; Grosspiculagia kolchida (Popova, 1937) Jansen, 1958; Ostertagia (Grosspiculagia) lasensis Assadov, 1953; Grosspiculagia lasensis Asadov, 1953; Skrjabinagia lasensis (Asadov, 1953) Andreeva, 1957; Muflonagia podjapolskyi Shul'ts, Andreeva and Kadenazii, 1954; Skrjabinagia podjapolskyi (Shul'ts, Andreeva, and Kadenazii, 1954) Andreeva, 1957; Grosspiculagia podjapolskyi (Shul'ts, Andreeva, and Kadenazii, 1954); Jansen, 1958; Skrjabinagia kolchida (Popova, 1937) Andreeva, 1957.]

Ostertagia mossi Dikmans, 1931/O.dikmansi Becklund and Walker, 1968. [Synonym of $O$. dikmansi: Skrjabinagia dikmansi (Becklund and Walker, 1968) Drózdz, 1971.]

Ostertagia ostertagi (Stiles, 1892) Ransom, $1907 /$ O.lyrata Sjöberg, 1926. [Synonyms of $O$. ostertagia: Strongylus ostertagi Stiles, 1892; $O$. caprae Andreeva and Nikolsky, 1957.] [Synonyms of O. lyrata: O. (Grosspiculagia) lyrata Sjöberg, 1926; Sjöbergia lyrata (Sjöberg, 1926) Sarwar, 1956; Grosspiculagia lyrata (Sjöberg, 1926) Jansen, 1958; Skrjabinagia lyrata (Sjöberg, 1926; Andreeva, 1957; Ostertagia occidentalis Gebauer, 1932 nec. Ransom, 1907; Camelostrongylus lyratus (Sjöberg, 1926) Durette-Desset, 1989.]

Species of Ostertagia are characteristic abomasal nematodes in ruminants throughout the world. The cur- rent cosmopolitan distribution for some species, particularly those in domestic stock, has been strongly influenced by translocation and introduction of hosts and parasites from Europe (Hoberg 1997). In contrast, species endemic to either the Palearctic or the Nearctic generally have characteristic distributions associated either with bovids or cervids (Drózdz 1965; Govorka et al, 1988). As noted earlier, there are five polymorphic species of Ostertagia recognized in wild ruminants from North America (Lichtenfels and Hoberg 1993).

Ostertagia bisonis circulates in pronghorn, bison, and mule deer across the northcentral plains into Canada. Morphologically, it is most similar to Teladorsagia circumcincta and $O$. ostertagi, but can be distinguished by the structure of the spicules, the copulatory bursa, and the dimensions of the esophageal valve (Becklund and Walker 1967b; Lichtenfels and Pilitt 1991); the minor male morphotype is $O$. kazakhstanica (see Lichtenfels and Pilitt 1991; Drózdz 1995). This ostertagiine is referred to the genus Orloffia by Drózdz (1995). It is not known to be pathogenic in wild ruminants but has been associated with significant clinical gastritis in cattle sharing common range with deer, pronghorn, and bison (Worley and Sharman 1966). Contrary to Worley and Sharman (1966), nematodes depicted in photomicrographs of tissue sections were mature adults rather than parasitic stages of larvae. This ostertagiine is known from cattle in Wyoming, Montana, and Colorado (Becklund 1964; Lichtenfels and Pilitt 1991).

Ostertagia gruehneri is restricted in distribution to the high latitudes of the Northern Hemisphere, and is a typical abomasal nematode in caribou and muskox across the Holarctic (Bye and Halvorsen 1983; Bye et al. 1987; Fruetel and Lankester 1989). Morphologically, $O$. gruehneri is most similar to $O$. leptospicularis and $O$. mossi, from which it can be distinguished based on the structure of the genital cone and spicules (Lichtenfels et al. 1990; Hoberg et al. 1993b; Lichtenfels and Hoberg 1993). Disease associated with infections of this species has not been observed. Irvine et al. (2000), however, suggested that $O$. gruehneri may have a role as a determinant of population fluctuations or cycles for reindeer. There are no records of this ostertagiine from cattle, sheep, or other domesticated hosts.

Ostertagia leptospicularis and its minor morphotype, $O$. kolchida, are distributed across the western Palearctic and occur in cervids and bovids (e.g., Drózdz 1965). Only recently has this species been reported in North America, with records being from cattle or caribou maintained in a captive herd (Rickard and Zimmerman 1986; Fruetel and Lankester 1989; Mulrooney et al. 1991). Records from wild cervids in North America are limited to mule deer and elk, but the parasite is considered to have an historically broader geographic distribution, particularly in the western United States (Hoberg et al. 1993b; Van Baren et al. 1996). The significance of $O$. leptospicularis is in its reported pathogenicity in cervids. It was implicated in winter mortality in red deer (Dunn 1983), where there was an apparent shift in the abundance (dominance) of o. leptospicularis relative to species of Spiculoptera- 
Hoberg, Kocan \& Rickard in Parasitic Diseases of Wild Mammals (Samuel, Pybus \& Kocan. eds.). lowa State University Press, 2001, 2nd ed.

gia. Additionally a concern is its potential for crosstransmission from cervids and its association with ostertagiosis in cattle in the United Kingdom and New Zealand (Borgsteede 1982; Hoberg et al. 1993b).

Ostertagia mossi and the associated minor morphotype, $O$. dikmansi, have a distribution restricted to eastern North America and have only been reported from white-tailed deer (Dikmans 1931; Becklund and Walker 1967b, 1968; Prestwood and Pursglove 1981, Forrester 1992; Hoberg et al. 1993b); it appears to be absent in the southeastern United States. Morphologically, this species is difficult to distinguish from $O$. leptospicularis, but can be identified based on the structure of the genital cone and terminal processes of the spicules in males (Hoberg et al. 1993b). Nematodes of this species are not considered to be pathogenic in the numbers typically encountered in white-tailed deer (prevalence to $70 \%$ and maximum of over 1000 nematodes at some localities) (Prestwood and Pursglove 1981; Forrester 1992).

Ostertagia ostertagi and the associated minor morphotype, $O$. lyrata, are ubiquitous parasites of domestic stock, principally cattle, throughout the world (Levine 1980). There are numerous records in wild ruminants in North America, and some reports have been linked to significant ostertagiosis (e.g., Conti and Howerth 1987). Generally, however, this ostertagiine occurs at low levels of intensity in wild bovids and cervids and would be unlikely to cause disease (see Prestwood and Pursglove 1981). It appears that $O$. ostertagi is found in wild ruminants only when range is shared with cattle.

\section{Genus Spiculopteragia Orloff, 1933}

Classification: Trichostrongyloidea:

Trichostrongylidae: Ostertagiinae.

Spiculopteragia asymmetrica (Ware, 1925) Orloff,

1933/S. quadrispiculata (Jansen, 1958) Durette-

Desset, 1982. [Synonym: S. asymmetrica: Ostertagia asymmetrica Ware, 1924; S. cervi (Cameron, 1931).][Synonyms: S. quadrispiculata: Apteragia quadrispiculata (Jansen, 1958) Durette-Desset, 1982; Skrjabinagia monodigitata Andrews, 1964.]

Spiculopteragia spiculoptera (Guschanskaia, 1931) Orloff, 1933/S. mathevossiani, Ruchliadeu, 1948.

[Synonyms: Ostertagia spiculoptera Guschanskaia, 1931; O. boehmi Gebauer, 1932; S. kotkascheni Asadov, 1952; S. (Petrowiagia) pigulski Ruchliadev, 1961 ; many authors list $S$. spiculoptera and $S$. boehmi as synonyms, Hinaidy et al. (1972) presented the argument that the later species name had priority.] [Synonyms: S. mathevossiani:

Rinadia mathevossiani (Ruchliadev, 1948)

Andreeva, 1957; Rinadia schulzi Grigorian, 1951; Rinadia caucasica Asadov, 1955; Rinadia

pavlovskyi Kadenazii and Andreeva, 1957; Rinadia quadrifurcata Andrews, 1964.$]$

Spiculopteragia suppereri Hinaidy and Pros1, 1978.

Among parasites that could be introduced with wild cervids from the Palearctic and New Zealand (e.g., $C$. elaphus elaphus, C. dama, C. nippon; roe deer, Capre- olus capreolus) are additional species of Spiculopteragia and other ostertagiines (e.g., Drózdz 1965, 1967; Kutzer and Hinaidy 1969; Govorka et al. 1988; Mason 1994).

Species of Spiculopteragia are typical parasites in the abomasum of cervids in the Palearctic (Drózdz 1965, 1966, 1967; Govorka et al. 1988). The occurrence of three species in North America can be attributed to introduction of cervids of exotic origin (Rickard et al. 1993). There are no records of $S$. asymmetrica from white-tailed deer on common range with fallow deer; $S$. spiculoptera has been reported once from white-tailed deer and from captive caribou (Tables 8.11, 8.13). Spiculopteragia suppereri was found in Pere David's deer imported to Texas (T.M.Craig, unpublished) and is recognized as a host-specific parasite in this cervid (Drózdz 1998). Disease conditions attributable to these species have not been observed in North America. Species of Spiculopteragia are generally restricted to cervid hosts, although records from Bos and Bison in Europe have been documented (Drózdz 1965, 1966, 1967, 1995; Suarez and Cabaret 1991).

\section{Genus Teladorsagia Andreeva \\ and Satubaldin, 1954}

Classification: Trichostrongyloidea:

Trichostrongylidae: Ostertagiinae.

Teladorsagia boreoarcticus Hoberg, Monsen, Kutz, and Blouin, 1999, with T. boreoarcticus forma major and $T$. boreoarcticus f. minor, respectively, for major and minor morphotype males.

Teladorsagia circumcincta (Stadleman, 1894) Drózdz, 1965/ T. trifurcata (Ransom, 1907) Drózdz, 1965/ T. davtiani Andreeva and Satubaldin, 1954. [Synonyms of T. circumcincta: Strongylus circumcincta Stadleman, 1894; Ostertagia circumcincta (Stadleman, 1894) Ransom, 1907; Stadelmania circumcincta (Stadleman, 1894) Sarwar, 1956; Ostertagiella circumcincta (Stadleman, 1894) Andreeva, 1957; Strongylus vicarius Stadleman, 1893; Strongylus cervicornis McFadyean, 1897 in part; Strongylus instabilis Julien, 1897; Ostertagia turkestanica Petrov and Shakhovtsova, 1926; Stadelmania turkestanica (Petrov and Shakhovtsova, 1926) Sarwar, 1956.] [Synonyms of Teladorsagia trifurcata: Ostertagia trifurcata Ransom, 1907; Stadelmania trifurcata (Ransom, 1907) Sarwar, 1956.] Lancaster and Hong (1981) and Drózdz (1965) consider $T$. davtiani to be a synonym of T. trifurcata; Daskalov (1974) and Becklund and Walker (1971) consider them separate. Based on ITS-2 sequences from rDNA, T. circumcincta is trimorphic (Stevenson et al. 1996).

Teladorsagia circumcincta and associated minor morphotypes now have a cosmopolitan distribution. This ostertagiine is a characteristic abomasal parasite in wild and domesticated bovids, and only occasionally is reported from cervid hosts in North America (Lichtenfels et al. 1988a,b; Hoberg et al. 1999). In a recent 
hypothesis, E.P. Hoberg (in Lictenfels et al. 1997) suggested that forms designated as $T$. circumcincta from historically isolated populations of wild bovids may represent a complex of cryptic but distinct species. Such may be indicated by the exceptionally broad morphological variation documented for $T$. circumcincta and respective morphotypes in wild and domestic bovids across the Holarctic (e.g., Becklund and Walker 1971). Supportive of this hypothesis, collections in muskox and caribou from the central Arctic of Canada revealed a cryptic polymorphic species which was described as Teladorsagia boreoarcticus by Hoberg et al. (1999).

Discovery of $T$. boreoarcticus raises questions about the identity of nematodes reported as $T$. circumcincta (or associated morphotypes) in wild ruminants across the Holarctic and suggests a broader complex of sibling species in wild ruminants of the Nearctic (e.g., in Dall's sheep, bighorn sheep, mountain goats, pronghorn, and cervids) (Hoberg et al. 1999). Detailed studies of nematodes reported as $T$. circumcincta in wild bovids and cervids from North America and the Palearctic are requisite and should include molecular level analyses.

In sheep, $T$. circumcincta is considered one of the most significant pathogens throughout the world (Levine 1980). Generally, levels of intensity observed in domestic sheep are not attained in wild hosts (Nielsen and Neiland 1974). There have been no records of disease attributable to this species in wild ruminants in North America.

Other species of ostertagiines also have been introduced with exotic bovids from Sub-Saharan Africa, India, and possibly South America and the Palearctic. In some cases the original source can no longer be determined; they are mentioned here because of the potential for cross-transmission to endemic North American bovids or to cattle and sheep.

Genus Camelostrongylus Orloff, 1933

Classification: Trichostrongyloidea:

Trichostrongylidae: Ostertagiinae:

Camelostrongylus mentulatus (Railliet and Henry,

1909) Orloff, 1933. [Synonyms: Ostertagia

mentulata Railliet and Henry, 1909; Marshallagia

mentulata (Railliet and Henry, 1909) Durette-

Desset, 1982.]

Camelostrongylus mentulatus is a pathogenic ostertagiine with a broad host range (camelids, bovids, and some cervids) and geographic distribution outside of North America. The exceptionally long and vermiculated spicules of the male are diagnostic for this ostertagiine (Gibbons and Khali1 1982). In the United States it has been reported in blackbuck antelope and llamas, but currently is not considered a common or widespread parasite (Rickard and Bishop 1991). This parasite, introduced into the United States (currently no records from Canada), is circulating in free-ranging herds of African bovids and llamas; there is considerable potential for dissemination to wild or domestic ruminants coinciding with transport of animals within North America. Thornton et al. (1973a,b) successfully infected sheep and goats with larvae of $C$. mentulatus from antelope; cattle were apparently refractory to infection. Parasitic gastritis, chronic emaciation, and death of the host may be the consequences of infection (see Rickard and Bishop 1991).

\section{Genus Longistrongylus LeRoux, 1931}

Classification: Trichostrongyloidea:

Trichostrongylidae: Ostertagiinae.

Longistrongylus curvispiculum (Gibbons, 1973)

Gibbons, 1977. [Synonym: Bigalkenema

curvispiculum Gibbons, 1973.]

Species of Longistrongylus are parasites of bovids in the region of Sub-Saharan Africa (Gibbons 1977). Currently, L. curvispiculum is established in freeranging herds of exotic bovids in Texas (Craig 1993) (Table 8.14). Although species of Longistrongylus appear to be relatively host specific, there is the potential for cross-transmission to wild and domestic ruminants in North America. Disease associated with infections by species of Longistrongylus has not been reported.

\section{Genus Trichostrongylus Looss, 1905}

Classification: Trichostrongyloidea:

Trichostrongylidae: Trichostrongylinae.

Common Name: Intestinal hair-worms.

Trichostrongylus askivali Dunn, 1964.

Trichostrongylus axei (Cobbold, 1879) Railliet and

Henry, 1909. [Synonyms: Strongylus gracilis

MacFadyean, 1896; S. tenuissimus Mazzanti, 1891.

T. extenuatus (Railliet, 1898).]

Trichostrongylus calcaratus Ransom, 1911.

Trichostrongylus colubriformis (Giles, 1892).

[Synonyms: T. instabilis (Railliet, 1893); T.

delicatus Hall, 1916; S. subtilis Looss, 1895.]

Trichostrongylus dosteri Maples and England, 1971.

Trichostrongylus longispicularis Gordon, 1933.

Trichostrongylus vitrinus Looss, 1905.

Trichostrongylus probolurus (Railliet, 1896).

[Synonym: Strongylus probolurus Railliet, 1896.]

Species of Trichostrongylus are parasites of either the abomasum or the small intestine and generally are uncommon. These are the smallest of the trichostrongylid nematodes that will be encountered as adult worms in bovid and cervid hosts. At the generic level, adults are readily identified by the prominent notch in the cuticle at the level of the excretory pore. In North America, these are the only trichostrongylids in which the synlophe is absent (Gibbons and Khalil 1982). Levine (1980), Maples and England (1971), and Pursglove et al. (1974) provide important diagnostic information at the species level.

The life cycle for trichostrongylines is direct, but there is no information for species such as T. askivali or $T$. dosteri, which are typical parasites of deer (Prestwood and Pursglove 1981). In T. axei and T. colubriformis, the third-stage infective larvae develop within 7-9 days under optimum conditions of temperature and 
moisture. Following ingestion of infective larvae, the prepatent period is $\sim 15-23$ days; patency extends up to 15 months for T. axei (see Levine 1980). Current evidence suggests that arrested development of the thirdor early fourth-stage larva is of limited significance among Trichostrongylus spp.

Prevalence and intensity of infection are generally low and usually appear to be under the threshold where disease might be expected. In cattle, usually in excess of 100,000 worms (single species infections) or 10,000 worms (multispecies infections) are required to produce clinical disease (Table 8.15 and 8.16). In these instances, infections can be associated with weight loss, general weakness, inappetence, and watery diarrhea and occasionally can lead to mortality of the host. Lesions have not been described in wild bovids or cervids but may be expected to resemble those typical of trichostrongylosis in cattle. In heavy infections, there may be hyperemia of the abomasum and the development of whitish, necrotic plaques (Levine 1980).

Species of Trichostrongylus other than T. askivali and $T$. dosteri are likely acquired on range shared with domestic sheep or cattle. There are few records of Trichostrongylus occurring in ruminants at subarctic to arctic latitudes.

\section{Genus Nematodirus Ransom, 1907}

Classification: Trichostrongyloidea: Molineidae: Nematodirinae.

Common Name: Thread-necked strongyles.

Nematodirus abnormalis May, 1920.

Nematodirus andersoni Durette-Desset and Samuel, 1989. [Synonyms: c.f. N. archari, North American records, see Durette-Desset and Samuel (1989).]

Nematodirus archari Sokolova, 1948.

Nematodirus becklundi Durette-Desset and Samuel, 1992.

Nematodirus davtiani Grigorian, 1949. [Synonym: $N$. rufaevastitatis Durbin and Honess, 1951.]

Nematodirus filicollis (Rudolphi, 1802) Ransom, 1907. [Synonyms: Ascaris filicollis Rudolphi, 1802; Strongylus filicollis (Rudolphi, 1802) Rudolphi, 1803; Fusaria filicollis (Rudolphi, 1802) Zeder, 1803; Oesophagostomum filicollis (Rudolphi, 1802) Stossich, 1899; N. furcatus May, 1920.]

Nematodirus helvetianus May, 1920.

Nematodirus maculosus Becklund, 1965.

Nematodirus odocoilei Becklund and Walker, 1967. [Synonym: records of $N$. filicollis in Odocoileus spp. may represent this species according to Becklund and Walker (1967a).]

Nematodirus oiratianus Raevskaia, 1929. [Synonyms: N. lanceolatus Ault, 1944. Lichtenfels and Pilitt (1983a) consider all North American records referable to the subspecies $N$. oiratianus interruptus; however, not all specimens were examined so some records of this species are equivocal.]

Nematodirus oiratianus interruptus Lichtenfels and Pilitt, 1983. [Synonyms: North American records of N. oiratianus Raevskaia, 1929; $N$. lanceolatus Ault, 1944.]
Nematodirus spathiger (Railliet, 1896). [Synonym:

Strongylus spathiger Railliet, 1896.]

Nematodirus skrjabini Mizkewitsch, 1929.

Nematodirus tarandi Hadwen, 1922. [Synonyms: $N$. skrjabini Mizkewitsch, 1929? Dikmans (1936) listed this species as a synonym of $N$. tarandi; however, Skrjabin et al. (1954) considered it distinct, but with $N$. tarandi referable to the genus Nematodirella.]

The genus Nematodirus is a speciose group that includes nematodes characteristic of either bovid or cervid hosts across the Holarctic (Kulmamatov 1974). There are in excess of 40 valid species, with 13 or 14 being found in wild ruminants from North America. These are among the largest of the trichostrongyloids in the small intestine (rarely abomasum) of bovids and cervids. They usually are recognized by the prominent cephalic vesicle, long, filiform spicules, a large copulatory bursa in the male, and large eggs, generally near $200 \mu \mathrm{m}$ in length. The synlophe and the spicule tips and bursa are diagnostic characters for distinguishing among the species. Lichtenfels and Pilitt (1983a) provided keys for species occurring primarily in domesticated hosts; additional pertinent information on sylvatic species can be found in Hoberg and Rickard (1988), Hoberg et al. (1989), Rickard and Lichtenfels (1989), and Durette-Desset and Samuel $(1989,1992)$. Infective third-stage and parasitic larvae can be recognized based on characters of the tail (Fruetel and Lankester 1989).

Consistent with other trichostrongyloids, the life cycle is direct; however, development to the infective third larval stage occurs entirely within the egg. Development time is from 3-4 weeks at optimum temperatures for N. filicollis, N. spathiger, and N. battus; following ingestion, the minimum prepatent period is $2-3$ weeks (Kates and Turner 1955; Thomas 1959). Epizootiological patterns for these species in the Pacific Northwest have been investigated by Rickard et al. (1989); data for other species are lacking.

Eggs and larvae are resistant to desiccation and low temperature, and overwinter survival has been documented. A limiting factor may be maximum temperatures attained in the summer, as larvae are intolerant to high temperatures. Transmission to the definitive host may have a marked seasonality and, in part, is mediated by precipitation and temperature (Marquardt et al. 1959; Gibson and Everett 1976, 1981; Rickard et al. 1989). Seasonally defined peaks of larval abundance are typical for Nematodirus spp. (e.g., Rickard et al. 1989). Thus, for some species in particularly harsh environments there may be only a single parasitic generation per year. This epizootiological picture would strongly influence the patterns of geographic and host distribution and the potential for disease associated with infections of Nematodirus spp.

Each species of Nematodirus has a well-defined host spectrum, such that species are usually limited in distribution to either cervids or bovids (Tables 8.1-8.12). Levels of prevalence and intensity vary according to the host, parasite, and geographic locality. For example 
in Odocoileus spp., the characteristic $N$. odocoilei has a widespread geographic range coinciding with its hosts. Prevalence generally ranges from 10\%-20\% with a maximum of $60 \%$ reported; intensity usually does not exceed several hundred worms (Pursglove et al. 1976; Forrester 1992). The maximum reported from one white-tailed deer was near 18,000 , but was considered to be exceptional (Pursglove et al. 1976). Species of Nematodirus are abundant in wild sheep, with $100 \%$ prevalence and a maximum of 70-6000 adult worms and 3000 larvae reported (Kistner et al. 1977). These levels of infection would not be atypical across the range of bighorn sheep (Becklund and Senger 1967; Uhazy and Holmes 1971); comparable levels have been documented for Dall's sheep in Alaska (Nielsen and Neiland 1974). These levels are considered to be below that where substantial disease might be observed, but in a synergistic manner could become significant in the presence of other strongyles and malnutrition (Becklund and Senger 1967).

Among nematodirines, overlap in the faunas of domestic and sylvatic hosts are related to the sharing of parasites characteristic of cattle and sheep (N. filicollis, $N$. spathiger, $N$. abnormalis and $N$. helvetianus) (Table 8.1). Generally, a degree of host specificity is observed for those species found either in wild bovids (e.g., $N$. becklundi and $N$. maculosus in mountain goat and $N$. andersoni in Dall's and bighorn sheep) or cervids (e.g., $N$. odocoile $i$ in deer) (Tables 8.1, 8.5, 8.6, 8.10, and 8.11). None of these species has been reported in domestic ruminants. Although the recently introduced and highly pathogenic $N$. battus has so far only been reported from sheep, cattle, and llamas in North America, there is some expectation that it could successfully parasitize such endemic cervids as deer or elk (Hoberg et al. 1986; Hoberg 1997).

Genus Nematodirella Yorke and Maplestone, 1926

Classification: Trichostrongyloidea: Molineidae: Nematodirinae.

Nematodirella alcidis (Dikmans, 1935). [Synonym: $N$. longispiculata alcidis Dikmans, 1935.]

Nematodirella antilocaprae (Price, 1927). [Synonyms: $N$. antilocaprae Price, $1927 ; N$. longispiculata antilocaprae Dikmans, 1935; Nematodirella longissimespiculata antilocaprae of Skrjabin and Shikhobalova, 1952.]

Nematodirella gazelli (Sokolova, 1948). [Synonym: N. longispiculata gazelli Sokolova, 1948.]

Nematodirella longissimespiculata (Romanovich, 1915). [Synonyms: Microcephalus longissime spiculatus Romanovich, 1915; N. longispiculata Yorke and Maplestone, 1926; N. longispiculata longispiculata Dikmans, 1935; $N$. longissimespiculata longissimespiculata Skrjabin and Skhikobalova, 1952.]

Systematics and taxonomy for this genus have been reviewed by Lichtenfels and Pilitt (1983b). Similar to Nematodirus, specimens of Nematodirella spp. are large strongyles generally from $10-40 \mathrm{~mm}$ in length.
Males are characterized by exceptionally long spicules, in excess of $4 \mathrm{~mm}$ (maximum over $12 \mathrm{~mm}$ in $N$. gazelli). The structure of the synlophe is diagnostic for males and females of the five Holarctic species; four species are known in wild ruminants from North America. Eggs are generally $>240 \mu \mathrm{m}$ in length; among infective, ensheathed larvae the caudal structure is diagnostic for some species (Fruetel and Lankester 1989).

These are typically parasites of the small intestine in cervids and bovids at high boreal to arctic latitudes across the Northern Hemisphere. Some species such as $N$. alcidis in moose appear to be largely host specific; in contrast, $N$. antilocaprae is known from mule deer, elk, and pronghorn. Additionally, $N$. alcidis is one of the few trichostrongyloids that is commonly found in moose throughout North America. Records of Nema todirella spp. from domestic hosts are exceptional.

Life cycles for species of Nematodirella currently are unknown, but likely are similar to those documented for Nematodirus. Detailed information for prevalence and intensity of infection generally are not available or are based on small, host sample sizes. For N. alcidis, Stock and Barrett (1983) reported 52\% prevalence and intensity ranging from 1 to 250 among 140 moose in Alberta; $1 \%$ of 186 elk were infected. There is no direct evidence of pathogenesis associated with infections of Nematodirella spp., and intensity and prevalence appear to be typically low.

STRONGYLATE FAUNA: A GENERAL OVERVIEW. Strongylate nematodes are common parasites in wild ruminants from North America. Numerical diversity ranges from a maximum of 28 species in Odocoileus virginianus to a minimum of 8 reported from Alces alces; the mean is 15 species per host (Tables 8.2-8.12). The range in species richness may in part reflect the degree of sampling effort and geographic distribution, particularly with the historical emphasis on parasitological studies of Odocoileus spp. This situation is likely to be more complex, however, as very few parasites are known from moose even though relatively large samples have been examined in some areas (Anderson and Lankester 1974). For example, Bergstrom (1975a) did not find Marshallagia in 60 moose from Montana; Spencer and Chatelain (1953) mention no parasites from moose in the Kenai Peninsula of Alaska; Stock and Barrett (1983) examined 140 moose from southeastern Alberta and found 3 species of strongyles; and C. A. Nielsen (unpublished) found 2 species in 25 moose from Alaska (Table 8.8).

This numerical diversity emphasizes the influence of host specificity (e.g., Spiculopteragia and Mazamastrongylus in Cervus spp. and Odocoileus spp., respectively) and apparent geographic limitations on the distribution of the relatively characteristic faunas associated with each host (e.g., Prestwood et al. 1975) (Tables 8.2-8.12). The importance of specificity, however, is variable, and in some instances the absence of this phenomenon accounts for the extensive host range documented for some strongyles (e.g., Suarez and 
Hoberg, Kocan \& Rickard in Parasitic Diseases of Wild Mammals (Samuel, Pybus \& Kocan. eds.). lowa State University Press, 2001, 2nd ed.

Cabaret 1991) (Table 8.1). Consequently, the faunas in wild ruminants are only partially segregated from those in domesticated sheep and cattle (Baker et al. 1957), but a relatively low percentage of the entire fauna is shared among these host groups. For example, cattle and sheep are the general source of infections by Haemonchus spp., O. ostertagi, Trichostrongylus spp., $N$. filicollis, N. spathiger, N. helvetianus, and Cooperia spp. in wild hosts; there is some suggestion based on high prevalence and intensity that circulation of $H$. contortus in white-tailed deer may not require cattle (see Forrester 1992). In contrast, M. marshalli, O. bisonis, O. leptospicularis, $P$. bullosa, $N$. oiratianus interruptus, and $O$. venulosum may be maintained primarily in wild bovids or cervids. These, along with T. circumcincta, would be expected on common range shared by wild and domesticated ruminants; however, " $T$. circumcincta" in wild bovids may represent an extensive complex of cryptic species which will further complicate our understanding of host distribution. A notable example of broad susceptibility to parasitism is seen in the infections of strongyles recorded in translocated muskoxen in contact with either domestic, semidomestic, or other sylvatic hosts (Alendal and Helle 1983).

On a worldwide basis, a comparison of the helminth faunas in a number of wild ruminants indicates that cross-transmission to domestic hosts may, in fact, be common (Dunn 1969). In most instances, however, helminth parasites of wild animals to which domestic stock are exposed appear to be of low pathogenicity. As a result, wild ruminants appear to be more likely to suffer from the effects of endoparasitism than do domestic cattle, sheep, and goats in areas of common grazing. For example, morbidity and mortality in captive and wild herds of muskoxen in contact with helminths derived from domestic hosts is documented (MacDonald et al. 1976; Alendal and Helle 1983). In general, it appears that in most free-ranging conditions, wild ruminants do not generally play a significant role in the spread or maintenance of helminth infections in domestic stock (Semenova 1984); one exception may be $O$. leptospicularis circulating among cervids, cattle, and sheep (Borgsteede 1982).

In some cases, significant disease may be associated with parasitism in an atypical host, such as that reported for $O$. bisonis in cattle, O. ostertagi in deer, or M. marshalli in domestic sheep (Worley and Sharman 1966; Oripov 1970; Conti and Howerth 1987). Additionally, it is possible that species currently recognized only as parasites of exotic and introduced bovids and cervids (Tables 8.13 and 8.14) may be capable of infecting both wild and domestic ruminants in North America.

Although cross-transmission of strongyles between host species does not appear to be a common occurrence in North America (Table 8.1), the basic biology associated with development and transmission of the various species of parasitic nematodes is similar (Govorka et al. 1988). For example, arrested development, as a mechanism for survival during periods of unfavorable environmental conditions, is a common phenomenon for many abomasal nematodes infecting domestic ruminants (Gibbs and Herd 1986; Williams 1986). Nematodes such as Mazamastrongylus and other ostertagiines that infect white-tailed deer also appear to undergo similar developmental changes as an integral part of their transmission. The seasonal timing of inhibition generally coincides with that of related genera and species in bovine hosts (Belem et al. 1993). In contrast, Halvorsen (1986) suggested that larval inhibition may not be critical in the transmission and survival of gastrointestinal strongyles in reindeer that exist in harsh winter environments of the Arctic.

Management strategies for most game species are constantly being modified or are subject to local custom or national and international jurisdiction (e.g., Gunn 1982; Klein 1996). Such strategies as translocation and reintroduction can be expected to directly influence the distribution of parasites and the potential for disease (Hoberg 1997; Hoberg et al. 1999). Likewise, changes in associations between wild species and humans, domestic species, and introduced or farmed exotic ruminants may also alter the significance for a diversity of parasitic organisms (Haigh 1996). Consequently, we are now making significant observations related to the importance of gastrointestinal parasites of wild mammals and are beginning to determine that many species may be important contributors to the health of their mammalian hosts. Some specific examples of the significance of parasitism can be derived from the studies conducted on white-tailed deer.

MANAGEMENT IMPLICATIONS: MORBIDITY AND MORTALITY. The best documented parasite fauna among North American ruminants is that found in white-tailed deer (Table 8.11). In North America, Odocoileus virginianus is perhaps the most abundant species of ruminant, and one that has shown a remarkable ability to adapt to changing or modified habitats within its potential range. Although information documenting the occurrence of gastrointestinal strongyles is notable, it is important to recall that parasites are not equal in their pathogenic potential. Consequently, it is of fundamental importance not only to identify the specific organism(s) present, but also to determine the approximate intensity of infection. Clinical signs such as weight loss, diarrhea, anorexia, anemia, and poor pelage can be indicative of, or associated with, endoparasitism in both domestic and wild ruminants. Other health problems, however, including malnutrition, toxicities, concurrent hemoparasitic infections, and numerous infectious diseases can lead to similar clinical signs. Thus, in investigations of endoparasitic infections in wild species, we are not always able to unequivocally determine the role of a variety of factors or disease agents that have influenced the range of observed clinical signs. As a result, we are often limited in our ability to make precise statements related to the parasite fauna and its direct association with morbidity and mortality.

Veterinary medicine has made some contributions in this area, particularly for the range of nematode species that may be found in the abomasum (Tables 8.15 and 
8.16: modified from Jordan and Stair 1983). For example, infection with 5000 to $9000 \mathrm{H}$. contortus is reported to result in notable morbidity in calves $<1$ year of age; infections $>10,000$ result in mortality. Among other genera the numbers of adult nematodes needed to produce mortality in calves of a similar age range from $>140,000$ for Trichostrongylus and $12,000-15,000$ for $O$. ostertagi (in Type II ostertagiasis). Synergistic effects between species of strongyles may result in morbidity at lower levels of intensity (Table 8.16).

Experimental and/or field data for clinical effects of strongyles in wild ruminants has been limited (e.g., Johnston et al. 1984) but is available for parasites such as $H$. contortus. For example, a naturally infected and malnourished deer was found to have 16,540 adult $H$. contortus (Prestwood and Kellogg 1971); additional mortality was seen in deer with average worm burdens of $>1000 \mathrm{H}$. contortus (Prestwood et al. 1973). A general guideline has been proposed where 75 adults of $H$. contortus per $\mathrm{kg}$ body weight is the level of infection where clinical signs become apparent (Foreyt and Trainer 1970; McGhee et al. 1981). These studies are consistent with those in domestic animals where $500->1000$ adults of $H$. contortus are considered pathogenic (Herlich 1962; Anderson et al. 1966; Jordan and Stair 1983). Thus, it appears that in some cases extrapolation of values from domestic hosts to wild ruminants may be valid.

We emphasize that the values for intensity of infection and their linkage to pathogenicity must not be overinterpreted, and it is vital not to focus on a particular numerical range as being of significance in the etiology of disease. We suggest this due to the array of factors that may influence the interaction between hosts and parasites, including different species of nematodes, host species, weight, age, immune status, nutritional plain, and environmental setting (e.g., ambient temperatures, availability of water and forage). Consequently, although these values may serve as rough baselines, each situation and species of bovid or cervid must be evaluated independently. In the absence of controlled studies with specific species of parasites in wild ruminants, cautious extrapolation from domestic stock may represent the only source of information on pathogenicity; these data must be interpreted in a conservative manner. Additionally, as addressed in the subsequent section, the subclinical effects of parasitism, specifically at the level of host population, must also be recognized.

An extension of studies of gastrointestinal nematodes, particularly in white-tailed deer, was the development of the "abomasal parasite count" or APC (Eve and Kellogg 1977). In the southeastern United States wildlife biologists have employed this method to correlate the intensity of infection by abomasal parasites with the local population density of deer. This was accomplished by comparing the APC with an independent rating of deer density relative to the carrying capacity of the habitat (Eve and Kellogg 1977). Using a graded scale correlating these factors, APCs were used to assist in management decisions related to manipulation of population density for deer. Specifically, management was tied to enhancing nutrition and natural immunity while reducing environmental contamination and minimizing the potential for transmission of parasites and related density-dependent disease conditions (Eve 1981). This procedure has been employed with mixed success in the southeastern United States, and its application to other regions has been problematic due to seasonal fluctuations in the abundance of parasites (Demarias et al. 1983; Waid et al. 1985). In Norway, Bye (1987) postulated an association linking poor physical condition, high population density, and highintensity infections by ostertagiine nematodes in reindeer. Thus, it appears that variation in seasonal prevalence and abundance and other factors should be considered in the application and validity of the APC.

\section{PARASITES AND HOST POPULATIONS: THEO-} RETICAL ISSUES. The potential for interaction of the sylvatic and domestic fauna is important in evaluating the potential for disease attributable to gastrointestinal strongyles. Of additional and critical importance is consideration of the synergistic interactions of parasites and habitat. Rather than pathogenesis and mortality, associated with exceptional or monospecific infections (e.g., haemonchiasis and ostertagiasis in deer: Conti and Howerth 1987; Forrester 1992), it may be the cumulative effects of mixed species that induce disease or reduce performance (e.g., Bye and Halvorsen 1983). The subclinical effects of strongyle infections and impairment of gastrointestinal function have been documented in domestic sheep (Sykes 1978; Coop and Angus 1981), and it would be expected that these observations represent a generality among wild and domestic ruminants. Additionally, in circumstances of a high prevalence of infection such as those reported for reindeer, strongyles may be important as a determinant of population dynamics of the host (Bye and Halvorsen 1983; Halvorsen 1986).

A dynamic linkage between hosts, parasites, and habitat stability related to density-dependent effects of parasitism by gastrointestinal nematodes was postulated by Grenfell $(1988,1992)$. In these instances, parasites may influence plant-host interactions by regulation of host population density. Feedback mechanisms would exist where increasing intensity of parasitism would be expected with increasing host density (e.g., Eve and Kellogg 1977; Bye 1987; Arneberg et al. 1996); high levels of parasitism lead to reduced food intake and reduced impact on habitat (Grenfell 1992). Empirical support for this contention derives from observations of depression of food intake in $R$. taran$d u s$ related to the intensity of infection by gastrointestinal nematodes (Arneberg et al. 1996). This can be linked in a density-dependent manner to mortality and future fecundity within the host population. For example, reindeer calves reared in high-density areas are lighter than those from comparatively underpopulated regions, an observation previously emphasized solely 
for food availability (Skogland 1990). Thus, infections of high intensity by ostertagiines in the abomasum can lead to reduced food intake and efficiency and can eventually influence growth in calves; such effects could be pronounced during lactation (Bye 1987). Eventual impacts on host demography and the potential for limitation in the growth of the host population would be predicted (Anderson 1980; Bye 1987). Reduced foraging activity also may result in altered patterns of exposure that influence transmission of parasites to hosts. Ultimately a reduction in food intake may constitute a constraint on parasite abundance in individuals and in host populations.

Parasites can exacerbate the effects of malnutrition and food availability, which is indicative of the complex association linking herbivores, nematodes, foraging dynamics, and habitat stability (Grenfell 1992; Arneberg et al. 1996). This association has been demonstrated in studies of parasitism in caribou and in feral populations of the Soay sheep (Bye 1987; Gulland 1992; Ameberg et al. 1996). The synergism of food shortage and immunosuppression may result in pathogenic infections resulting in host mortality (Gulland 1992). Obvious implications are evident with respect to the effects of subclinical and clinical parasitism among a diversity of sylvatic ruminants. Thus, it is necessary to also consider the importance of aggregation of parasite populations and the distribution of parasites in natural host populations (e.g., Shaw and Dobson 1995; Hudson and Dobson 1995) rather than focusing on disease in individual animals.

CONSERVATION BIOLOGY, GLOBAL CHANGE, AND PARASITISM. Human activities constitute a major control on the distribution and dissemination of helminth parasites and other pathogens (Vitousek et al. 1996; Hoberg 1997; Hoberg et al. 1999). The cosmopolitan ranges for many strongyles have largely resulted from the breakdown of isolating mechanisms or ecological barriers. Thus, alteration of historical associations through ecological disruption and long-range translocation will figure prominently in the continued emergence of pathogenic nematode parasites (Dobson and May 1986a,b; Scott 1988; Woodford and Rossiter 1994; Hoberg 1997; Daszek et al. 2000).

Translocation and introduction exposes indigenous wildlife to new disease organisms and concomitantly can expose introduced animals to novel pathogens. Rapid and long distance transport, introduction and maintenance of domesticated stock, or establishment of free-ranging or captive herds on small reserves can be important factors in the dissemination and amplification of pathogenic nematodes and other parasites (Dobson and May 1986b; Haigh 1996; Daszek et al. 2000). Woodford and Rossiter (1994) outlined protocols for minimization of risk by screening and intervention related to management practices for wild hosts. Careful planning, site selection (e.g., physical, ecological, presence of alternative hosts), quarantine, screening, and monitoring are requisite to controlling the introduction of potential pathogens (Haigh 1996). Development of comprehensive databases on host and geographic distribution of strongyles and other infectious agents can lead to a predictive framework that can be used as the basis for prevention (e.g., current development of a database for nematode parasites of Holarctic bovids and cervids) (E.P. Hoberg, unpublished). In conjunction with modern systematics to elucidate aspects of host-parasite evolutionary history, these become powerful tools in limiting the potential impacts of pathogenic nematodes (Hoberg 1997).

Baseline information on host behavior and ecology also aid in the control process. For example, Syroechkovskii (1995) identified the role of long-range migrations by reindeer and caribou as important determinants on the distribution of pathogens. Grazing and foraging behavior are also important factors to consider with respect to how different species of ruminants may be exposed to infection by parasites with direct life cycles. Habitat use influences prevalence and intensity, particularly in situations where animals are confined. There is an expectation of pathogenicity due to nematodes in hosts in relatively restricted conservation areas where the effects of crowding, concentration at waterholes, malnutrition, and heavy range exploitation (often in conjunction with domestic hosts) may be observed. A shift from the use of optimal to suboptimal forage or habitats may expose animals to parasitism; for example, a shift from a browsing to a grazing behavior. There is also a particular concern about the impact of host density in natural conservation reserves where transmission of parasites may be enhanced (Dobson and May 1986a,b; Scott 1988; Aguirre and Starkey 1994).

Only recently has the synergistic influence of anthropogenic and climatologically driven global change been discussed with reference to helminths and other parasites (e.g., Dobson and Carper 1992). Peters (1992) addressed a range of biotic responses to climate change (increase in global temperature), including alteration of habitat, and latitudinal shifts in distribution and abundance of plants and animals. For host-parasite systems in temperate regions, Dobson and Carper (1992) postulated that increasing temperatures and desiccation could limit the distribution of some parasites. Epizootiological patterns would be altered, possibly leading to reduced levels of parasitism or to the wider dissemination of species tolerant of higher ambient temperatures. Alternatively, the response of hosts to pathogens would also be modified (Dobson and Carper 1992) where (1) increased stress can change the degree of susceptibility to parasitism and parasite-induced mortality (Esch et al. 1975); (2) changes in host and parasite distribution can lead to overlapping ranges and increased host-switching; and (3) broader dissemination of some pathogens would be expected. In the Arctic and subarctic, however, changes may be particularly pronounced and radically different from those in boreal regions. At high latitudes, climatological changes and impacts may lead to (1) latitudinal shifts in geographic ranges; (2) extension of the 
growth season, with earlier springs, and a broadened window for transmission; (3) reduction in developmental times linked to higher temperatures; (4) decrease in generation times; (5) increase in rates of transmission, larval survival, and availability; and (6) increases in prevalence and intensity for some parasites.

The potential for amplification of parasite populations and emergence of subclinical or clinical effects is dependent on the degree to which ambient environmental and ecological conditions are limiting factors of parasite abundance in Arctic host-parasite systems. Genetics of Teladorsagia boreoarcticus are compatible with a small effective population in muskox and caribou from the central Canadian Arctic. Constraints on parasite abundance may result from small and dispersed host populations (particularly for muskox), ephemeral reservoirs of infective larvae, and a combination of limiting physical and environmental factors acting synergistically to define seasonal windows for transmission (Hoberg et al. 1999). Further, mechanisms controlling the population dynamics for such species as Marshallagia marshalli and Ostertagia gruehneri are complex; the intrinsic environment within the host may be most significant for the former, whereas extrinsic abiotic factors may limit the latter (Halvorsen et al. 1999; Irvine et al. 2000). Abundance and transmission also are affected by where and how populations of nematodes are sequestered during the winter, whether as adults and arrested larvae in ruminant hosts or as infective larvae in the external environment (Irvine et al. 2000). Such shifts in parasite abundance and patterns of transmission could have an impact on populations of large ruminants that serve as the primary food resources of native and subsistence cultures in the Arctic (Hoberg 1997) and other regions. The linkage of anthropogenic and climatological global change must be recognized in future management plans for wild ruminants in North America and throughout the world.

STRONGYLES, SYSTEMATICS, AND RUMINANT HOSTS: A SYNTHESIS. Strongylate nematodes are significant components of global biodiversity and can represent potential and real threats to economically important wild and domestic ruminants. The North American strongylate fauna is a relatively diverse assemblage distributed among both wild and domestic hosts. These parasites are ubiquitous and have characteristic relationships, host and geographic distributions, and predictable life cycles and patterns of transmission. Documentation of parasite biodiversity through survey and inventory is the first step in defining the relationships of endemic and introduced faunas in ruminants. Systematics provides the foundation for elucidating the phylogenetic, coevolutionary, and biogeographic history of host-parasite assemblages (Brooks and Hoberg 2000). This historical database constitutes the predictive framework for recognizing contemporary interactions with naive-host groups, and the behavior of parasites introduced into new geographic and ecological settings. This information, in conjunction with ongoing research, which examines pathogenesis of strongyles in individual hosts and host populations, will become increasingly important with the escalation of environmental change across a diversity of ecosystems. An understanding of pathogenic parasites such as the strongylate nematodes characteristic of ruminants will remain critical within the context of wildlife biology, conservation, and the management of recovering, threatened, or endangered species.

ACKNOWLEDGMENTS. We thank Dr. Carol Nielsen for allowing access to records of parasitological studies in Alaskan ruminants. Dr. Anne Gunn, Mr. Alasdair Veitch, Mr. John Nishi, and Dr. Brett Elkin of the Department of Resources, Wildlife and Economic Development, Government of the Northwest Territories, Canada, and Dr. Susan Kutz of the University of Saskatchewan contributed to studies of helminth parasites of ruminants in the Arctic. Improvements of this manuscript resulted from critical reviews kindly prepared by Dr. Lydden Polley and Dr. S. Kutz of the University of Saskatchewan and Dr. Dante Zarlenga of the Agricultural Research Service, Beltsville, Maryland

\section{LITERATURE CITED}

Adrian, W.J. (Ed). 1981. Manual of common wildlife diseases in Colorado. Denver: Colorado Division of Wildlife.

Aguirre, A.A., and E.E. Starkey. 1994. Wildlife disease in U.S. national parks: Historical and coevolutionary perspectives. Conservation Biology 8:654-661.

Allen, R.W. 1955. Parasites of mountain sheep in New Mexico, with new host records. The Journal of Parasitology 41:583-587.

- 1962. Extent and sources of parasitism in pronghorn antelope. Transactions of the Interstate Antelope Conference 1962, pp. 48-51.

Allen, R.W., and H.G. Erling. 1964. Parasites of bighorn sheep and mule deer in Arizona with new host records. The Journal of Parasitology 50:38.

Allen, R.W., and C.B. Kennedy. 1952. Parasites of bighorn sheep in New Mexico. Proceedings of the Helminthological Society of Washington 19:39.

Alendal, E., and O. Helle. 1983. Helminth parasites of muskoxen Ovibos moschatus in Norway incl. Spitsbergen and in Sweden, with a synopsis of parasites reported from this host. Fauna Norveigica 4:41-52.

Anderson, N., J. Armour, R.M. Eadie, W.F.H. Jarrett, F.W. Jennings, J.S.D. Ritchie, and G.M. Urquhart. 1966. Experimental Ostertagia ostertagi infections in calves: Results of single infections with five graded dose levels of larvae. American Journal of Veterinary Research 27:1259-1265.

Anderson, R.C., and M.W. Lankester. 1974. Infectious and parasitic diseases and arthropod pests of moose in North America. Naturaliste Canada 101:23-50.

Anderson, R.M. 1980. Depression of host population abundance by direct life cycle macroparasites. Journal of Theoretical Biology 82:283-311.

Andrews, S.J., and M.B. Lancaster. 1988. Use of ivermectin in deer. Veterinary Record 123:354.

Arneberg, P., and I. Folstad. 1999. Predicting effects of naturally acquired abomasal nematode infections on growth 
Hoberg, Kocan \& Rickard in Parasitic Diseases of Wild Mammals (Samuel, Pybus \& Kocan. eds.). lowa State University Press, 2001, 2nd ed.

rate and food intake in reindeer using serum pepsinogen levels. Journal of Parasitology 85:367-369.

Arneberg, P., I. Folstad, and A.J. Karter. 1996. Gastrointestinal nematodes depress food intake in naturally infected reindeer. Parasitology 112:213-219.

Baker, M.R., and R.C. Anderson. 1975. Seasonal changes in abomasal worms (Ostertagia sp.) in white-tailed deer (Odocoileus virginianus) at Long Point, Ontario. Canadian Journal of Zoology 53:87-96.

Baker, M.R., and S.R. Pursglove, Jr. 1976. Oesophagostomum Molin 1861 in white-tailed deer (Odocoileus virginianus) of North America. The Journal of Parasitology 62:166-168.

Baker, N.F., and R.A. Fisk. 1986. Seasonal occurrence of infective nematode larvae in California Sierra foothill pastures grazed by cattle. American Journal of Veterinary Research 47:1680-1685.

Baker, N.F., W.M. Longhurst, and J.R. Douglas. 1957. Experimental transmission of gastrointestinal nematodes between domestic sheep and Columbian black-tailed deer. 22nd North American Wildlife Conference, pp. $160-168$.

Becklund, W.W. 1962. Distribution and hosts of the ruminant parasite Teladorsagia davtiani Andreeva and Satubaldin, 1954 (Nematoda: Trichostrongylidae) in the United States. The Journal of Parasitology 48:469.

- 1964 . Revised checklist of internal and external parasites of domestic animals in the United States and possessions and in Canada. American Journal of Veterinary Research 25:1380-1416.

-. 1965. Nematodirus maculosus sp. n. (Nematoda: Trichostrongyloidea) from the mountain goat, Oreamnos americanus, in North America. The Journal of Parasitology $51: 945-947$

- 1966. Suppression of Nematodirus rufaevastitatis Durbin and Honess, 1951, a nematode described from Ovis aries, as a synonym of Nematodirus davtiani Grigorian, 1949. Proceedings of the Helminthological Society of Washington 33:199-201.

Becklund, W.W., and C. Senger. 1967. Parasites of Ovis canadensis in Montana, with a checklist of the internal and external parasites of Rocky Mountain bighorn sheep in North America. The Journal of Parasitology $53: 157-165$.

Becklund. W.W., and M.L. Walker. 1967a. Nematodirus odocoile $i \mathrm{sp} . \mathrm{n}$. (Nematoda: Trichostrongylidae) from the black-tailed deer, Odocoileus hemionus, in North America. The Journal of Parasitology 53:392-394.

1967b. Redescriptions of the nematodes Ostertagia bisonis Chapin, 1925, of cattle and wild ruminants, and Ostertagia mossi of deer. The Journal of Parasitology 53:1273-1280.

— 1968. Ostertagia dikmansi sp. n. (Nematoda: Trichostrongylidae) from deer, Odocoileus virginianus, with a key to species of medium stomach worms of Odocoileus in North America. The Journal of Parasitology $54: 441-444$.

—_ 1971. Nomenclature and morphology of Ostertagia trifurcata Ransom, 1907, with data on spicule lengths of five stomach worms of ruminants. The Journal of Parasitology 57:508-516.

Belem, A.M.G., C.E. Couvillion, C. Siefker, and R.N. Griffin. 1993. Evidence for arrested development of abomasal nematodes in white-tailed deer. Journal of Wildlife Diseases 29:261-265.

Bergstrom, R.C. 1975a. Prevalence of Marshallagia marshalli (Orlov, 1933) in wild ruminants in Wyoming. Proceedings of the Oklahoma Academy of Sciences 55:101-102. -. 1975b. Incidence of Marshallagia marshalli Orloff 1933 in Wyoming sheep, Ovis aries, and pronghorn antelope, Antilocapra americana. Proceedings of the Helminthological Society of Washington 42:61-63.
Bergstrom, R.C., and T. Kass. 1982. Nematodes and nematodirosis. In Diseases of wildlife in Wyoming, 2nd ed. Ed. E.T. Thorne, N. Kingston, W.R. Jolley, and R.C. Bergstrom. Cheyenne: Wyoming Game and Fish Department Special Publication, pp. 199-201.

Bergerud, A.T. 1971. The population dynamics of Newfoundland caribou. Wildlife Monographs 25:1-55.

Blood, D.A. 1963. Parasites from California bighorn sheep in southern British Columbia. Canadian Journal of Zoology 41:9133-918.

Boddicker, M.L., and E.J. Hugghins. 1969. Helminths of big game mammals in South Dakota. The Journal of Parasitology 55:1067-1074.

Boddicker, M.L., E.J. Hugghins, and A.H. Richardson. 1971. Parasites and pesticide residues of mountain goats in South Dakota. The Journal of Wildlife Management 35:94-103.

Borgsteede, F.H.M. 1982. The infectivity of some nematode parasites of reindeer (Rangifer tarandus L) and elk (Alces alces $\mathrm{L}$ ) for cattle and sheep. Zeitschrift für Parasitenkunde 67:211-215.

- 1988. Studies on the epidemiological pattern and control of nematode infection in Cervidae. In The management and health of farmed deer. Ed. H.W. Reid. Dordrecht, Netherlands: Kluwer Academic Publishers, pp. $13-22$.

Bos, G.N. 1967. Range types and their utilization by muskox on Nunivak Island, Alaska: A reconnaissance study. M.Sc. Thesis, University of Alaska, Fairbanks, 113 pp.

Brandborg, S.M. 1955. Life history and management of the mountain goat in Idaho. Idaho Department of Fish and Game, Wildlife Bulletin 2, 142 pp.

Brooks, D.R., and E.P. Hoberg. 2000. Triage for the biosphere: The need and rationale for taxonomic inventories and phylogenetic studies of parasites. Comparative Parasitology 67:1-25.

Brugh, T.H., Jr. 1971. A survey of internal parasites of a feral herd of fallow deer (Dama dama) in Alabama. Journal of the Alabama Academy of Sciences 42:133.

Burtner, R.H., and W.W. Becklund. 1971. Prevalence, geographic distribution, and hosts of Cooperia surnabada Antipin, 1931, and C. oncophora (Railliet, 18988) Ransom, 1907 in the United States. The Journal of Parasitology $57: 191-192$.

Bush, A.O., K.D. Lafferty, J.M. Lotz, and A.W. Shostak. 1997. Parasitology meets ecology on its own terms: Margolis et al, revisited. The Journal of Parasitology 83:575-583.

Bye, K. 1987. Abomasal nematodes from three Norwegian wild reindeer populations. Canadian Journal of Zoology 65:677-680

Bye, K., and O. Halvorsen. 1983. Abomasal nematodes in the Svalbard reindeer (Rangifer tarandus platyrhynchus Vrolik). Journal of Wildlife Diseases 19:101-105.

Bye, K., O. Halvorsen, and K. Nilssen. 1987. Immigration and regional distribution of abomasal nematodes of Svalbard reindeer. Journal of Biogeography 14:451-458.

Cameron, A.E. 1923. Notes on buffalo: Anatomy, pathological conditions and parasites. British Veterinary Journal 79:331-336.

. 1924. Some further notes on buffalo. Veterinary Journal 80:413-417.

Campbell, A.J.D., R.B. Gasser, and N.B. Chilton. 1995. Differences in ribosomal DNA sequence of Strongylus species allows identification of single eggs. International Journal of Parasitology 25:359-365.

Capelle, K.J. 1966. The occurrence of Oestris ovis L. (Diptera: Oestridae) in the bighorn sheep from Wyoming and Montana. The Journal of Parasitology 52:618-621.

Card, C.S. 1903. Report of the committee on infectious disease of cattle, bison, and llama. Proceedings of the U.S. Animal Health Association 97:171-185.

Chapin, E.A. 1925. New nematodes from North American mammals. Journal of Agricultural Research 30:677-681. 
Chapman J.A., and G.A. Feldhamer (Eds). 1982. Wild mammals of North America, biology, management, and economics. Baltimore: Johns Hopkins University Press, $1147 \mathrm{pp}$.

Choquette, L.P.E., L.K. Whitten, G. Rankin, and C.M. Seal. 1957. Note on parasites found in reindeer (Rangifer tarandus) in Canada. Canadian Journal of Comparative Medicine 21:199-203

Christiansen, C.M. D.S. Zarlenga, and L.C. Gasbarre. 1994a Ostertagia, Haemonchus, Cooperia, and Oesophagostomum: Construction and characterization of genus-specific DNA probes to differentiate important parasites of cattle. Veterinary Parasitology 78:93-100.

. 1994b. Identification of a Haemonchus placei-specific DNA probe. Journal of the Helminthological Society of Washington 61:249-252.

Connan, R.M. 1991. Type II ostertagiosis in farmed red deer Veterinary Record 128:233-235.

. 1996. Hypobiosis in the ostertagids of red deer and the efficacy of ivermectin and fenbendazole against them. Veterinary Record 140:203-205.

Conti, J.A., and E.W. Howerth. 1987. Ostertagiosis in a whitetailed deer due to Ostertagia ostertagi. Journal of Wildlife Diseases 23:159-162

Cook, T.W., B.T. Ridgeway, R. Andrews, and J. Hodge. 1979. Gastro-intestinal helminths of white-tailed deer (Odocoileus virginianus) of Itlinois. Journal of Wildife Diseases 15:405-408.

Coop, R.L., and K.W. Angus. 1981. How helminths affect sheep. Veterinary Record 108:4-11.

Couey, F.M. 1950. Rocky Mountain bighorn sheep of Montana. Montana Fish and Game Commission, Big Game Biologist Bulletin 2, 90 pp.

Cowan, I.McT. 1951. The diseases and parasites of big game animals of western Canada. Report of the 5th Annual Game Conference, Victoria, British Columbia, pp. $37-64$

Craig, T.M. 1993. Longistrongylus curvispiculum (Nematoda: Trichostrongyloidea) in free-ranging exotic antelope in Texas. Journal of Wildlife Diseases 29.516-517.

Cram, E.B. 1925. Cooperia bisonis a new nematode from buffalo. Journal of Agricultural Research 30:571-573.

Das, K.M., and J.H. Whitlock. 1960. Subspeciation in Haemonchus contortus (Rudolphi, 1803) Nemata, Trichostrongyloidea. Cornell Veterinarian 50:182-197.

Daskalov, P. 1974. On the reproductive relationships between Ostertagia circumcincta, Teladorsagia davtiani, and $O$. trifurcata (Nematoda: Trichostrongylidae) [In Bulgarian]. Izvestiva na Tsentralnata Kheminthologichna Laboratoriya, Sofia 17:59-72.

Daszak, P. A.A. Cunningham, and A.D. Hyatt. 2000. Emerging infectious diseases of wildlife-Threats to biodiversity and human health. Science 287:443-449.

Davidson, W.R., and C.B. Crow. 1983. Parasites, diseases and health status of sympatric populations of sika deer and white-tailed deer in Maryland and Virginia. Journal of Wildlife Diseases 19:345-348.

Davidson, W.R., and V.F. Nettles. 1988. Field manual of wildlife diseases in the southeastern United States. Athens, GA: Southeastern Cooperative Wildlife Disease Study.

Davidson, W.R., and A.K. Prestwood. 1979. Apteragia pursglovei sp. n. (Trichostrongyloidea: Trichostrongylidae) from the white-tailed deer, Odocoileus virginianus. The Journal of Parasitology 65:280-284.

Davidson, W.R., M.B. McGhee, V.F. Nettles, and L.C. Chappell. 1980. Haemonchosis in white-tailed deer in the southeastern United States. Journal of Wildlife Diseases 16:499-508

Davidson, W.R., J.M. Crum, J.L. Blue, D.W. Sharp, and J.H. Philips. 1985. Parasites, diseases and health status of sympatric populations of fallow deer and white-tailed deer in Kentucky. Journal of Wildlife Diseases 21:1533-159.
Davidson, W.R., J.L. Blue, L.B. Flynn, S.M. Shea, R.L. Marchinton, and J.A. Lewis. 1987. Parasites, diseases and health status of sympatric populations of sambar deer and white-tailed deer in Florida. Journal of Wildlife Diseases $23: 267-272$

Davis, J.W., and R.C. Anderson (Eds). 1971. Parasitic diseases of wild mammals. Ames: Iowa State University Press.

Demarais, S., H.A. Jacobson, and D.C. Guynn. 1983. Abomasal parasites as a health index for white-tailed deer in Mississippi. The Journal of Wildlife Management 47:247-252.

Dieterich, R.A. (Ed). 1981. Alaskan wildlife diseases. Fairbanks: University of Alaska.

Dikmans, G. 1931. Two new species of nematode worms of the genus Ostertagia from Virginia deer, with a note on Ostertagia lyrata. Proceedings of the United States National Museum 79:1-6.

1932. Abstract of report before the Helminthological Society of Washington. The Journal of Parasitology 19:83-84.

1936. A note on the identity of Nematodirus tarandi Hadwen, 1922, and Nematodirus skrjabini Mitzkevitsch, 1929 (Nematoda: Trichostrongyloidea). Proceedings of the Helminthological Society of Washington 2:56.

- 1939. Helminth parasites of North American semidomesticated and wild ruminants. Proceedings of the Helminthological Society of Washington 6:97-101.

. 1942. New host-parasite records. Proceedings of the Helminthological Society of Washington 9:65.

Dobson, A., and R. Carper. 1992. Global warming and potential changes in host-parasite and disease vector relationships. In Global warming and biological diversity. Ed. R.L. Peters and T.E. Lovejoy. New Haven: Yale University Press, pp. 201-220.

Dobson, A.P., and R.M. May. 1986a. Patterns of invasions by pathogens and parasites. In Ecological Studies. Vol. 58, Ecology of biological invasions of North America and Hawaii. Ed. H.A. Moore and J.A. Drake. New York: Springer-Verlag, pp. 58-76.

Dobson, A.P., and R.M. May. 1986b. Disease and conservation. In Conservation biology and the science of scarcity and diversity. Ed. M.E. Soulé. Sunderland, MA: Sinaeur Associates, pp. 345-365.

Doster, G.L., and M. Friend. 1971. Spiculopteragia (Nematoda) from deer of North America. The Journal of Parasitology 57:468.

Drózdz, J. 1965. Studies on helminths and helminthiases in Cervidae I. Revision of the subfamily Ostertaginae Sarwar, 1956, and an attempt to explain phylogenesis of its representatives. Acta Parasitological Polonica 13:445-481. - 1966. Studies on the helminths and helminthiases in Cervidae II. The helminth fauna in Cervidae in Poland. Acta Parasitological Polonica 14:1-13

- 1967. Studies on helminths and helminthiases in Cervidae III. Historical formation of heiminthofauna in Cervidae. Acta Parasitological Polonica 14:27-300.

1974. The question of genetic isolation and of permanent coincidence of some species of the subfamily Ostertagiinae. In Proceedings of the Third International Congress of Parasitology, Munich, Germany, vol. 1, pp. $477-478$.

1995. Polymorphism in the Ostertaginae LopezNeyra, 1947, and comments on the systematics of these nematodes. Systematic Parasitology 32:91-99.

1998. A record of Spiculopteragia suppereri (Nematoda: Trichostrongylidae) in farmed Elaphurus davidianus Cervidae in Poland. Acta Parasitologica Polonica 43:109-110.

Dunn, A.M. 1969. The wild ruminant as reservoir host of helminth infection. In Diseases in free-living wild animals. Ed. A. McDiarmid. New York: Academic Press, pp.221-246. 
Hoberg, Kocan \& Rickard in Parasitic Diseases of Wild Mammals (Samuel, Pybus \& Kocan. eds.). lowa State University Press, 2001, 2nd ed.

Chapter 8 / GASTROINTESTINAL STRONGYLES IN WILD RUMINANTS / 223

1983. Winter deaths in red deer: A preliminary report on abomasal parasite burdens. Publication of the Veterinary Deer Society 1:17-25.

Durette-Desset, M.-Cl. 1982. Sur les divisions génériques des nématodes Ostertagiinae. Annales de Parasitologie Humaine et Comparee 57:375-381.

. 1983. Keys to the genera of the superfamily Trichostrongyloidea. In $\mathrm{CIH}$ keys to the nematode parasites of vertebrates, No. 10. Ed. R.C. Anderson and A.G. Chabaud. Farnham Royal, UK: Commonwealth Agricultural Bureaux, pp. 1-86.

_ - 1985. Trichostrongyloid nematodes and their vertebrate hosts: Reconstruction of the phylogeny of a parasitic group. Advances in Parasitology 24:239-306.

___ 1989. Nomenclature proposée pour les espèces décrites dans la sous-famille des Ostertagiinae LopezNeyra, 1947. Annales de Parasitologie Humaine et Comparee 64:356-373.

Durette-Desset, M.-Cl., and A.G. Chabaud. 1977. Essaie de classification des nématodes Trichostrongyloidea. Annales de Parasitologie Humaine et Comparee 52:539-558.

- 1993. Nomenclature des Strongylida au-dessus du groupe-famille. Annales de Parasitologie Humaine et Comparee 68:111-112.

Durette-Desset, M.-Cl., and W.M. Samuel. 1989. Nematodirinae (Nematoda: Trichostrongyloidea) d'Antilocapra et d'Ovis en Alberta. Canada. Annales Parasitologie Humaine e: Comparee 64:469-477.

. 1992. Nematodirinae (Nematoda: Trichostrongyloidea) chez l'Oreamnos americanus en Alberta, Canada, description du Nematodirus becklundi sp. nov. Canadian Journal of Zoology 70:212-219.

Durette-Desset, M.-Cl., J.P. Hugot, P. Darlu, and A.G. Chabaud. 1999. A cladistic analysis of the Trichostrongyloidea (Nematoda). International Journal for Parasitology 29:1065-1086.

Esch, G.W., J.W. Gibbons, and J.E. Bourque. 1975. An analysis of the relationship between stress and parasitism. The American Midland Naturalist 93:339-353.

Eve, J.H. 1981. Management implications of disease. In Diseases and parasites of white-tailed deer. Ed. W.R. Davidson, F.A. Hayes, V.F. Nettles, and F.E. Kellogg. Tallahassee, FL: Tall Timbers Research Station Miscellaneous Publication No. 7, pp. 413-423.

Eve, J.H., and F. Kellogg. 1977. Management implications of abomasal parasites of southeastern white-tailed deer. The Journal of Wildlife Management 41:169-177.

Folstad, I., P. Arneberg, and A.J. Karter. 1996. Antlers and parasites. Oecologia 105:556-558.

Foreyt, W., and W.M. Samuel. 1979. Parasite of white-tailed deer of the Welder Wildlife Refuge in southern Texas: A review. In Proceedings of the First Welder Wildlife Foundation Symposium. Ed. D.L. Drawe. Sinton, TX: Welder Wildlife Foundation, pp. 105-132.

Foreyt, W, and D.O. Trainer. 1970. Seasonal parasitism changes in two populations of white-tailed deer in Wisconsin. The Journal of Wildlife Management 44:758-764.

Forrester, D.J. 1992. Parasites and diseases of wild mammals in Florida. Gainesville: University Press of Florida, 459 $\mathrm{pp}$.

Fowler, M. (Ed). 1993. Zoo and wildlife animal medicine. Current therapy 3. Philadelphia, PA: W.B. Saunders Co.

Fruetel, M., and M.W. Lankester. 1988. Nematodirella alcidis (Nematoda: Trichostrongyloidea) in moose of northwestern Ontario. Alces 24:159-163.

1989. Gastrointestinal helminths of woodland and barren ground caribou (Rangifer tarandus) in Canada, with key to species. Canadian Journal of Zoology 67:2253-2269.

Georgi, J.R., and C.E. McCulloch. 1989. Diagnostic morphometry: Identification of helminth eggs by discrimi- nant analysis of morphometric data. Journal of the Helminthological Society of Washington 56:44-57.

Gibbons, L.M. 1977. Revision of the genera Longistrongylus LeRoux, 1931, Kobusinema Ortlepp, 1963, and Bigalkenema Ortlepp, 1963 (Nematoda: Trichostrongylidae). Journal of Helminthology 51:41-62.

. 1979. Revision of the genus Haemonchus Cobb, 1898 (Nematoda: Trichostrongylidae). Systematic Parasitology 1:3-24.

Gibbons, L.M., and L.F. Khalil. 1982. A key for the identification of genera of the nematode family Trichostrongylidae Leiper, 1912. Journal of Helminthology 56:185-233.

Gibbs, H.C., and R.P. Herd. 1986. Nematodiasis in cattle. importance, species involved, immunity and resistance. Veterinary Clinics of North America: Food Animal Practice 2:211-224.

Gibbs, H.C., and J.S. Tener. 1958. On some helminth parasites collected from the musk ox (Ovibos moschatus) in the Thelon Game Sanctuary, Northwest Territories. Canadian Journal of Zoology 36:529-532.

Gibson, T.E., and G. Everett. 1976. The ecology of freeliving stages of Nematodirus filicollis. Research in Veterinary Science 20:158-161.

. 1981. Ecology of freeliving stages of Nematodirus battus. Research in Veterinary Science 31:233-327.

Gilmore, R.E., and Allen, R.W. 1960. Helminth parasites of pronghorn antelope (Antilocapra americana) in New Mexico with new host records. Proceedings of the Helminthological Society of Washington 27:69-73.

Goldsby, A.I. and Eveleth, D.H. 1954. Internal parasites in North Dakota antelope. The Journal of Parasitology 40:637-648.

Govorka, Ia., L.P. Maklakova, Ia. Mitukh, A.N. Pel'gunov, A.S Rykovskii, M.K. Semenova, M.K. Sonin, B. Erkhardova-Kotrla, and V. Iurashek. 1988. Gel'minty dikikh kopytnykh Vostochnoii Evropy. Moskva: Akademiia Nauk SSSR, Laboratoria Gel'mintologii, Izdatel'stvo Nauka, 207 pp.

Gray, G.G., D.B. Pence, and C.D. Simpson. 1978. Helminths of sympatric Barbary sheep and mule deer in the Texas panhandle. Proceedings of the Helminthological Society of Washington 45:139-141.

Grenfell, B.T. 1988. Gastrointestinal nematode parasites and the stability and productivity of intensive ruminant grazing systems. Philosophical Transactions of the Royal Society of London, Series B 321:541-563.

1992. Parasitism and the dynamics of ungulate grazing systems. American Naturalist 139:907-929.

Grenfell, B.T., and F.M.D. Gulland. 1995. Introduction: Ecological impact of parasitism on wildlife host populations. Parasitology 111(supplement): S3-S14.

Gulland, F.M.D. 1992. The role of parasites in soay sheep (Ovis aries $\mathrm{L}$ ) mortality during a host population crash. Parasitology 105:493-503.

- 1995. The impact of infectious diseases on wildlife populations-A review. In Ecology of infectious diseases in natural populations. Ed. B.T. Grenfell and A.P. Dobson. Cambridge: Cambridge University Press, pp. $20-51$.

Gunn, A. 1982. Muskox, Ovibos moschatus. In Wild mammals of North America: Biology management and economics. Ed. J.A. Chapman and G.A. Feldhammer. Baltimore: Johns Hopkins University Press, pp. 1021-1035.

Hadwen, I.A.S. 1922. Nematodirus tarandi a new species of nematode from the reindeer. The Journal of Parasitology 9:35.

Hadwen, S and LI. Palmer 1922 Reindeer in Alaska United States Department of Agriculture Bulletin No. 1089. Washington, D.C.: U.S. Government Printing Office, 74 pp.

Haigh, J.C. 1996. Management practices to minimise infectious and parasitic diseases of farmed and ranched 
cervids and bison. Revue Scientifique et Technique Office International des épizooties 15:209-226.

Hailey, T.L., J.W. Thomas, and R.M.Robinson. 1966. Pronghorn die-off in the Trans-Pecos, Texas. The Journal of Wildlife Management 30:488-496.

Halvorsen, O. 1986. Epidemiology of reindeer parasites. Parasitology Today 12:334-339.

Halvorsen, O., and K. Bye. 1999. Parasites, biodiversity, and population dynamics in an ecosystem in the high Arctic. Veterinary Parasitology 84:205-227.

Halvorsen, O., A. Stein, J. Irvine, R. Langvatn, and S. Albon. 1999. Evidence for continued transmission of parasitic nematodes in reindeer during the Arctic winter. International Journal for Parasitology 29:567-579

Herd, R.P. 1986. Epidemiology and control of nematodes and cestodes in small ruminants, northern United States. Veterinary Clinics of North America: Food Animal Practice. 2:355-362.

Herlich, H. 1962. Studies on calves experimentally infected with four nematode species. American Journal of Veterinary Research 23:521-528.

Heuer, D.E., J.H. Phillips, W.J. Rudersdorf, and J.P. Harley. 1975. Range extension records for Cooperia curticei, Ostertagia ostertagi, Setaria yehi, and Trichuris ovis in white-tailed deer from Kentucky. Proceedings of the Helminthological Scoiety of Washington 42:141-143.

Hinaidy, H.K., V.C. Guttieres, and R. Supperer. 1972. Die Gastrointestinal-Helminthen des Rindes in Österreich. Zentralblatt für Veterinámedizin 19:679-695.

Hoar, K.L., D.E. Worley, and K.E. Aune. 1996. Parasite loads and their relationship to herd health in the highlands bighorn sheep herd in southwestern Montana. Biennial Symposium North American Wild Sheep and Goat Coun cil $10: 57-65$.

Hoberg, E.P. 1996. Emended description of Mazamastrongylus peruvianus (Nematoda: Trichostrongylidae), with comments on the relationships of the genera Mazamas trongylus and Spiculopteragia. The Journal of Parasitology 82:470-477.

1997. Parasite biodiversity and emerging pathogens: A role for systematics in limiting impacts on genetic resources. In Global genetic resources: Access ownership and intellectual property rights. Ed. K.E. Hoagland and A.Y. Rossman. Washington, DC: Association of Systematics Collections, pp. 77-89.

Hoberg, E.P., and A.V. Khrustalev. 1996. Re-evaluation of Mazamastrongylus dagestanica (Trichostrongylidae) with descriptions of the synlophe, genital cone and other structural characters. The Journal of Parasitology 82:778-787

Hoberg, E.P., and J.R. Lichtenfels. 1992. Morphology of the synlophe and genital cone of Parostertagia heterospiculum (Trichostrongylidae) with comments on the subfamilial placement of the genus. Systematic Parasitology 22:1-16

. 1994. Phylogenetic systematic analysis of the Trichostrongylidae (Nematoda), with an initial assessment of coevolution and biogeography. The Journal of Parasitology 80:976-996.

Hoberg, E.P. and L.G. Rickard. 1988. Morphology of the synlophe of Nematodirus maculosus (Trichostrongyloidea) with comments on the evolution of Nematodirus spp. among the Caprinae (Artiodactyla). Proceedings of the Helminthological Society of Washington 55:160-164.

Hoberg, E.P. G.L Zimmerman, and J R. Lichtenfels. 1986. First report of Nematodirus battus (Nematoda: Trichostrongyloidea) in North America: Redescription and comparison to other species, Proceedings of the Helminthological Society of Washington 53:80-88.

Hoberg, E.P., G.L. Zimmerman, L.G. Rickard, and D.J. Schons. 1988. Efficacy of febantel against naturally acquired gastrointestinal nematodes in calves, and recognition of Oesophagostomum venulosum in Oregon cattle. American Joumal of Veterinary Research 49:1540-1542. Hoberg, E.P., M. Fruetel, and L.G. Rickard. 1989. Synlophe of Nematodirus odocoilei (Trichostrongyloidea) from deer and caribou in North America with comments on the evolution of Nematodirus spp. among the Cervidae (Artiodactyla). Canadian Journal of Zoology 67:1489-1494

Hoberg, E.P., J.R. Lichtenfels, and P.A. Pilitt. 1993a. Synlophe of Hyostrongylus rubidus (Trichostrongylidae), with evaluation of structural characters supporting affiliation with the Ostertagiinae. Journal of the Helminthological Society of Washington 60:219-233.

- 1993b. Comparative morphology of Ostertagia moss and Ostertagia dikmansi (Trichostrongylidae) from Odocoileus virginianus and comments on other Ostertagia spp. from the Cervidae. Systematic Parasitology 24:111-127.

Hoberg, E.P., K. Monsen, S. Kutz, and M.S. Blouin. 1999. Structure, biodiversity and historical biogeography of nematode faunas in Holarctic ruminants: Morphological and molecular diagnoses for Teladorsagia boreoarcticus sp. n. (Nematoda: Ostertagiinae), a dimorphic cryptic species in muskoxen (Ovibos moschatus). Journal of Parasitology 85:910-934.

Hoeve, J., D.G. Joachim, and E.M. Addison. 1988. Parasites of moose (Alces alces) from an agricultural area of eastern Ontario. Journal of Wildlife Diseases 24:371-374.

Honess, R.F., and J.W. Scott. 1942. Annual Report, Wyoming Agricultural Experiment Station (1941-1942), pp $27-28$

Honess, R.F., and K.B. Winter. 1956. Diseases of Wildlife in Wyoming. Wyoming Game and Fish Commission, Bulletin 9, $279 \mathrm{pp}$.

Hout, J., and M. Beaulieau. 1984. Relationship between parasitic infection levels and body fat reserves in George River caribou. In Proceedings of the 2 nd North American Caribou Workshop. Ed. T.C. Meredith and A.M. Martell. pp. 317-327.

Hudson, P.J., and A.P. Dobson. 1995. Macroparasites Observed patterns in naturally fluctuating animal populations. In Ecology of infectious diseases in natural populations. Ed. B.T. Grenfell and A.P. Dobson. Cambridge: Cambridge University Press, pp. 144-176.

Humbert, J.F., and J. Cabaret. 1995. Use of random amplified polymorphic DNA for identification of ruminant trichostrongylid nematodes. Parasitology Research 81:1-5.

Irvine, R.J., A. Stein, O. Halvorsen, R. Langvatn, and S. Albon. 2000. Life-history strategies and population dynamics of abomasal nematodes in Svalbard reindeer (Rangifer tarandus platyrhynchus). Parasitology 120:297-311.

Isenstein, R.S. 1971. The polymorphic relationship of Cooperia oncophora (Railliet, 1898) Ransom, 1907, to Cooperia surnabada Antipin, 1931 (Nematoda: Trichostrongylidae). The Journal of Parasitology 57:316-319.

Jansen, J. 1989. A concise history of the Ostertaginae LopezNeyra, 1947 (Nematoda: Trichostrongyloidea) and a discussion on its composition. Acta Leidensia 58:151-159.

Jean, M., R. Petanaude, J. Frechette, Y. Elazhary, Y.R. Higgins, A. Tremblay, and I. Juniper. 1982. Exploratory study of the health status of caribou of the George River herd. Quebec City: Quebec Department of Recreation. Fish and Game, Wildlife Research Branch.

Jensen, L.A., J.A. Short, and F.L. Andersen. 1982. Internal parasites of Odocoileus hemionus of central Utah. Proceedings of the Helminthological Society of Washington 49:317-319

Johnson, R.L. 1974. Bighom sheep 1973. A biological evaluation of the Tucannon Bighorn with notes on other Washington sheep. Olympia: Washington Department of Game, $69 \mathrm{pp}$. - 1975. Bighorn sheep 1974. An evaluation of bighorn sheep in the Sinlahekin area of northcentral Washington 
Hoberg, Kocan \& Rickard in Parasitic Diseases of Wild Mammals (Samuel, Pybus \& Kocan. eds.). lowa State University Press, 2001, 2nd ed.

with notes on other Washington sheep. Olympia: Washington Department of Game, $39 \mathrm{pp}$.

Johnston, J.T., A.S. Familton, R. McAnulty, and A.R. Sykes. 1984. Pathogenicity of O. circumcincta, O. ostertagi, and H. contortus in weanling stag fawns (Cervus elaphus). New Zealand Veterinary Journal 32:177-179.

Jordan, H., and E.L. Stair. 1983. Documenting clinical gastrointestinal parasitism: Worm burdens-A valuable tool. American Association of Laboratory Diagnosticians 26:241-248.

Kates, K.C., and J.H. Turner. 1955. Observations on the life cycle of Nematodirus spathiger, a nematode parasitic in the intestine of sheep and other ruminants. American Journal of Veterinary Research 16:105-115.

Kerr, G.R., and J.C. Holmes. 1966. Parasites of mountain goats in west-central Alberta. The Journal of Wildlife Management 30:786-790.

Kistner, T.P., S.M. Matlock, D. Wyse, and G.E. Mason. 1977. Helminth parasites of bighorn sheep in Oregon. Journal of Wildlife Diseases 13:125-130.

Klein, D.R. 1996. Structures for caribou management and their status in the circumpolar north. Rangifer (special issue) 9:245-251.

Kulmamatov, A. 1974. O vidovom sostave roda Nematodirus Ransom, 1907. Materialy Nauchnykh Konferentsii Vsesoiuznogo Obshchestva Gel'mintologii.26:1337-140.

Kutzer, E. 1987. The application of the anthelmintic Ivomec (ivermectin) in game animals [In German]. In Verhandlungsbericht des XXI Internationalen Symposiums des Österreichischen Wildgehegeverbandes, Vienna, Austria, pp. 7-17.

Kutzer, E., and H. K. Hinaidy. 1969. Die Parasiten der wildebenden Widerkäuer Österreichs. Zeitschrift für Parasitenkunde 32:354-368.

Lancaster, M.B., and S.J. Andrews. 1991. Red deer, nematodes, and anthelmintics. Veterinary Record 128:411.

Lancaster, M.B., and C. Hong. 1981. Polymorphism in nematodes. Systematic Parasitology 3:28-31.

_ 1990 . The identification of females within the subfamily Ostertagiinae Lopez-Neyra, 1947. Veterinary Par asitology 35:21-27.

Lancaster, M.B., C. Hong, and J.F. Michel. 1983. Polymorphism in the Trichostrongylidae. In Concepts in nematode systematics. Ed. A.R. Stone, H.M. Platt, and L.F. Khalil. London, UK: Academic Press, pp. 293-302.

Levine, N. 1963. Weather, climate and bionomics of ruminant nematode larvae. Advances in Veterinary Science 8:215-261.

- - 1980. Nematode parasites of domestic animals and man, 2nd ed. Minneapolis, MN: Burgess Publishing Co., $477 \mathrm{pp}$.

Lichtenfels, J.R. 1977. Differences in cuticular ridges among Cooperia spp. of North American ruminants with an illustrated key to species. Proceedings of the Helminthological Society of Washington 44:111-119.

_- - 1980a. Keys to the genera of the superfamilies Ancylostomatoidea and Diaphanocephaloidea. In $\mathrm{CIH}$ keys to the nematode parasites of vertebrates, No. 8. Ed. R.C. Anderson, A.G. Chabaud, and S. Wilmott. Farnham Royal, UK: Commonwealth Agricultural Bureaux, pp. 1-26.

$1980 \mathrm{~b}$. Keys to the genera of the superfamily Strongyloidea. In $\mathrm{CIH}$ keys to the nematode parasites of vertebrates, No. 7. Ed. R.C. Anderson, A.G. Chabaud, and S. Wilmott. Farnham Royal, UK: Commonwealth Agricultural Bureaux, pp. 1-41.

Lichtenfels, J.R., and E.P. Hoberg. 1993. The systematics of nematodes that cause ostertagiasis in domestic and wild ruminants in North America: An update and a key to species. Veterinary Parasitology 46:33-53.

Lichtenfels, J.R., and P.A. Pilitt. 1983a. Cuticular ridge patterns of Nematodirus (Nematoda: Trichostrongyloidea) parasitic in domestic ruminants of North America, with a key to species. Proceedings of the Helminthological Society of Washington 50:261-274.

. 1983b. Cuticular ridge patterns of Nematodirella (Nematoda: Trichostrongyloidea) of North American ruminants, with a key to species. Systematic Parasitology 5:271-285.

1989. Cuticular ridge patterns of Marshallagia marshalli and Ostertagia occidentalis (Nematoda: Trichostrongyloidea) parasitic in ruminants of North America. Proceedings of the Helminthological Society of Washington 56:173-182.

-. 1991. A redescription of Ostertagia bisonis (Nematoda: Trichostrongyloidea) and a key to species of Ostertagiinae with a tapering lateral synlophe from domestic ruminants in North America. Journal of the Helminthological Society of Washington 58:231-244.

Lichtenfels, J.R., P.A. Pilitt, and M.B. Lancaster. 1988a. Cuticular ridge patterns of seven species of Ostertaginae (Nematoda) parasitic in domestic ruminants. Proceedings of the Helminthological Society of Washington 55:77-86. - 1988b. Systematics of the nematodes that cause ostertagiasis in cattle, sheep, and goats in North America. Veterinary Parasitology 27:33-12.

Lichtenfels, J.R., P.A. Pilitt, and M.Fruetel. 1990. Cuticular ridge pattern in Ostertagia gruehneri and Ostertagia arctica (Nematoda: Trichostrongyloidea) from caribou, Rangifer tarandus. Journal of the Helminthological Society of Washington 57:61-68.

Lichtenfels, J.R., E.P. Hoberg, P.A. Pilitt, and A.M.G. Belem. 1993. A comparison of the cuticular ridge patterns and other morphological characters of Mazamastrongylus odocoilei and Mazamastrongylus pursglovei (Nematoda: Trichostrongyloidea) from white-tailed deer, Odocoileus virginianus. Systematic Parasitology 24:1-15.

Lichtenfels, J.R., P.A. Pilitt, and E.P. Hoberg. 1994. New morphological characters for identifying individual specimens of Haemonchus spp. (Nematoda: Trichostrongyloidea) with a key to species in ruminants of North America. The Journal of Parasitology 80:107-119.

Lichtenfels, J.R., E.P. Hoberg, and D.S. Zarlenga. 1997. Systematics of gastrointestinal nematodes of domestic ruminants: Advances 1992-1995, and proposals for future research. Veterinary Parasitology 72:225-245.

Locker, B. 1953. Parasites of bison in northwestern USA. The Journal of Parasitology 3:58-59.

Loken, N.I., J.C. Schlotthauer, H.J. Kurtz, and P.D Karns. 1965. Pneumostrongylus tenuis in Minnesota moose (Alces alces). Bulletin Wildlife Disease Association 1:7.

Longhurst, W.M., and J.R. Douglas. 1953. Parasite interrelationships of domestic sheep and columbian black-tailed deer. 18th North American Wildlife Conference, pp.168-188.

Low, W.A. 1976. Parasites of woodland caribou in Tweedsmuir Provincial Park, British Columbia. Canadian Field Naturalist 90:189-191.

Lucker, J.T., and G. Dikmans. 1945. The distribution of Pseudostertagia bullosa and some new records of nematodes from pronghorn antelope (Antilocapra americana). Proceedings of the Helminthological Society of Washington $12: 2-4$

MacDonald, D.W., W.M. Samuel, and J.O.C. Hunter. 1976. Haemonchosis in a captive muskox calf. Canadian Veterinary Journal 17:138-139.

MacKintosh, C.G., P.C. Mason, T. Manley, K. Baker, and R. Littlejohn. 1985. Efficacy and pharmacokinetics of febantel and ivermectin in red deer (Cervus elaphus). New Zealand Veterinary Journal 33:127-131.

Maples, W.P., and R.B. England. 1971. Trichostrongylus dosteri $\mathrm{sp}$. n. (Nematoda: Trichostrongylidae): A parasite of the white-tailed deer, Odocoileus virginianus (Zimmermann). American Midland Naturalist 86:506-508. 
Hoberg, Kocan \& Rickard in Parasitic Diseases of Wild Mammals (Samuel, Pybus \& Kocan. eds.). lowa State University Press, 2001, 2nd ed.

Maples, W.P., and H.E. Jordan. 1966. A new host record for Obeliscoides cuniculi (Graybill, 1923) Graybill, 1924 The Journal of Parasitology 52:49.

Marquardt, W.C., D.H. Fritts, C.M. Senger, and L. Seghetti. 1959. The effect of weather on the development and survival of the free-living stages of Nematodirus spathiger (Nematoda: Trichostrongyloidea). The Journal of Parasitology 45:431-439.

Marsh, H. 1938. Pneumonia in Rocky Mountain bighorn sheep. Journal of Mammalogy 19:214-219.

Mason, P. 1994. Parasites of deer in New Zealand. New Zealand Journal of Zoology 21:39-47.

McCullough, D.R., and E.R. Schneegas. 1966. Winter observations on the Sierra Nevada bighorn sheep. California Fish and Game 52:68-84.

McGhee, M.B., V.F. Nettles, E.A. Rollor, A.K. Prestwood, and W.R. Davidson. 1981. Studies on cross-transmission and pathogenicity of Haemonchus contortus in white-tailed deer, domestic cattle and sheep. Journal of Wildlife Diseases 17:353-364.

McKenzie, M.E., and W.R. Davidson. 1989. Helminth parasites of intermingling axis deer, wild swine and domestic cattle from the island of Molokai, Hawaii. Journal of Wildlife Diseases 25:252-257.

Mulrooney, D.M., J.K. Bishop, and G.L. Zimmerman. 1991. First report of Ostertagia leptospicularis (Nematoda: Trichostrongyloidea) in calves (Bos taurus) from North America. Journal of the Helminthological Society of Washington 58:260-262.

Nielsen, C.A., and K.A. Neiland. 1974. Sheep disease report, vol. 14. Juneau: Alaska Department of Fish and Game, $104 \mathrm{pp}$.

Oripov, A.O. 1970. Marshallagiosis of sheep [In Russian]. In Materialy Pyatoi Ob'edinennoi Konferentsii, pp. 12-137.

Payne, R.L., W.P. Maples, and J.F. Smith. 1967. The occurrence of Oesophagostomum cervi Mertts, 1948, in whitetailed deer (Odocoileus virginianus) of the southeastern United States. The Journal of Parasitology 53:691.

Peters, R.L. 1992. Conservation of biological diversity in the face of climate change. In Global warming and biological diversity. Ed. R.L. Peters and T.E. Lovejoy. New Haven: Yale University Press, pp. 15-30.

Pilmore, R.E. 1961. General investigations of diseases and parasites. Colorado Department of Fish and Game Report No. 10, pp. 10l-102.

Phillips, J.H., J.P. Harley, and W.J. Rudersdorf. 1974. New host records for Setaria yehi Disset, 1966, and range extension records for Dictyocaulus viviparus (Bloch, 1782) and Ostertagia mossi Dikmans, 1931, in fallow deer (Dama dama L). Proceedings of the Helminthological Society of Washington 41:250.

Prestwood, A.K., and F.E. Kellogg. 1971. Naturally occurring haemonchosis in a white-tailed deer. Journal of Wildlife Diseases 7:133-134.

Prestwood, A.K., and S.R. Pursglove. 1981. Gastrointestinal nematodes. In Diseases and parasites of white-tailed deer. Ed. W.R. Davidson, F.A. Hayes, V.F. Nettles, and F.E. Kellogg. Tallahassee, FL: Tall Timbers Research Station Miscellaneous Publication No. 7., pp. 318-349.

Prestwood, A.K., H.A. Hayes, J.H. Eve, and J.F. Smith. 1973. Abomasal helminths of white-tailed deer in southeastern United States, Texas, and the Virgin Islands. Journal of the American Veterinary Medical Association 163:556-561.

Prestwood, A.K., F.E. Kellogg, S.R. Pursglove, and F.A Hayes. 1975. Helminth parasitisms among intermingling insular populations of white-tailed deer, feral cattle and feral swine. Journal of the American Veterinary Medical Association 166:787-789.

Pursglove, S.R., Jr. 1976. Eucyathostomum webbi sp. n. (Strongyloidea: Cloacinidae) from white-tailed deer (Odocoileus virginianus). The Journal of Parasitology 62:574-578.
Pursglove, S.R., Jr., G.L. Doster, and A.K. Prestwood. 1974. Trichostrongylus askivali Dunn, 1964, and Ostertagia ostertagi (Stiles, 1892) in white-tailed deer (Odocoileus virginianus) of the southeastern United States. The Journal of Parasitology 60:1059-1060.

Pursglove, S.R., A.K. Prestwood, V.F. Nettles, and F.A. Hayes. 1976. Intestinal nematodes of white-tailed deer in southeastern United States. Journal of the American Veterinary Medical Association 169:896-900.

Quortrup, E.R., and R.L. Sudheimer, 1944. Some wildlife cases of particular interest. Journal of the American Veterinary Medical Association 104:29.

Ransom, B.H., and M.C. Hall. 1912. A new nematode, Ostertagia bullosa, parasitic in the alimentary tract of sheep. Proceedings of the United States National Museum 42:175-179.

Richardson, M.L., and S. Demarais. 1992. Parasites and condition of coexisting populations of white-tailed and exotic deer in south-central Texas. Journal of Wildlife Diseases 28:485-489.

Rickard, L.G., and J.K. Bishop. 1991. Helminth parasites of llamas (Lama glama) in the Pacific Northwest. Journal of the Helminthological Society of Washington 58:110-115.

Rickard, L.G., and J.R. Lichtenfels. 1989. Nematodirus archari (Nematoda: Trichostrongyloidea) from ruminants in North America with a description of the synlophe and the female. Canadian Journal of Zoology 67:1708-1714.

Rickard, L.G., and G.L. Zimmerman. 1986. First report of Ostertagia kolchida (Nematoda: Trichostrongyloidea) from North America. Proceedings of the Helminthological Society of Washington 53:136-138.

Rickard, L.G., E.P. Hoberg, J.K. Bishop, and G.L. Zimmerman. 1989. Epizootiology of Nematodirus battus, N. filicollis, and N. spathiger (Nematoda: Trichostrongyloidea) in western Oregon. Proceedings of the Helminthological Society of Washington 56:104-115.

Rickard, L.G., E.P. Hoberg, N.M. Allen, G.L. Zimmerman, and T.M. Craig. 1993. Spiculopteragia spiculoptera and S. asymmetrica (Nematoda: Trichostrongyloidea) from red deer (Cervus elaphus) in Texas. Journal of Wildlife Diseases 29:512-515.

Rush, W.M. 1932. Northern Yellowstone elk study. Montana Fish and Game Commission, $131 \mathrm{pp}$.

Samuel, W.M., and D.R. Gray. 1974. Parasitic infection in muskoxen. The Journal of Wildlife Management 38:775-782.

Samuel, W.M., M.W. Barrett, and G.M. Lynch. 1976. Helminths in moose of Alberta. Canadian Journal of Zoology 54:307-312

Samuel, W.M., W.K. Hall, J.G. Stelfox, and W.D. Wishart. 1977. Parasites of mountain goat, Oreamnos americanus (Blainville), of west central Alberta with a comparison of the helminths of mountain goat and Rocky Mountain bighorn sheep, Ovis c. canadensis Shaw. In Proceedings of the First International Mountain Goat Symposium, Kalispell, MT. Ed. W. Samuel and W.G. MacGregor. Victoria, BC: British Columbia Ministry of Recreation and Conservation, pp. 212-225.

Scott, M.E. 1988. The impact of infection and diseases on animal population: Implications for conservation biology. Conservation Biology 2:40-56.

Semenova, M.K. 1984. Studies on the circulation of Strongylata of domestic animals [In Russian]. In Gel'minty sel'skokhozyaistvennykh i okhotnich'e-promyslovykh zhivotnykh. Ed. M.D. Sonin. Moscow: Akademiia Nauk, SSSR, pp. 128-134.

. 1987. Survival of larval trichostrongylids of wild ruminants [In Russian]. Trudy Gel'mintologicheskoi Laboratorii 35:127-134

Semenova, M.K., and lu.E. Korosteleva. 1980. Study of the life cycle of Spiculopteragia alcis (Stongylata: Trichostrongylidae) a parasite of wild ungulates [In Russ- 
ian]. In Fauna nechernozem'ia ii okhrana vosproizvedenie I ispol'zovanie. Moscow: Kalinin, SSSR, Gel'mintologicheskii Laboratorii, pp. 126-131.

Shaw, D.J., and A.P. Dobson. 1995. Patterns of macroparasite abundance and aggregation in wildlife populations: A quantitative review. Parasitology 111 (supplement): S111-S133.

Shaw, J.N. 1947. Some parasites of Oregon wild life. Oregon Agricultural Experiment Station, Technical bulletin No. $11,16 \mathrm{pp}$.

Skogland, T. 1990. Density dependence in a fluctuating wild reindeer herd; maternal versus offspring effects. Oecologia $84: 442-450$.

Skrjabin, K.I., N.P. Shikhobalova, and R.S. Schul'ts. 1954. Trichostrongyloidea of animals and man [In Russian]. Osnovy nematology III. Moscow: Akad Nauk SSSR, 683 pp. [English Translation (1960). Springfield, VA: National Technical Information Service No. OTS6021124.]

Sommer C. 1996. Digital image analysis and identification of eggs from bovine parasitic nematodes. Journal of Helminthology 70:143-151.

Spencer, C.C. 1943. Notes on the life history of Rocky Mountain sheep in the Tarryall Mountains of Colorado. Journal of Mammalogy 24:1-11.

Spencer, D.L., and E.F. Chatelain. 1953. Progress in management of the moose of southcentral Alaska. In Transactions of the 18th North American Wildife Conference, pp. 541-552.

Stevenson, L.A., R.B. Gasser, and N.B. Chilton. 1996. The ITS-2 rDNA of Teladorsagia circumcincta, $T$. trifurcata and $T$, davtiani (Nematoda: Trichostrongylidae) indicates that these taxa are one species. International Journal for Parasitology 26:1123-1126

Stock, T.M., and M.W. Barrett. 1983. Helminth parasites of the gastrointestinal tracts and lungs of moose (Alces alces) and wapiti (Cervus elaphus) from Cypress Hills, Alberta, Canada. Proceedings of the Helminthological Society of Washington 50:246-251.

Strohlein, D.A., C.B. Crow, and W.R. Davidson. 1988. Distribution of Spiculopteragia pursglovei and $S$. odocoilei (Nematoda: Trichostrongyloidea) from white-tailed deer (Odocoileus virginianus) in the southeastern United States. The Journal of Parasitology 74:347-349.

Stubblefield, S.S., D.B. Pence, and R.J. Warren. 1987. Visceral helminth communities of sympatric mule and white-tailed deer from the Davis Mountains of Texas. Journal of Wildlife Diseases 23:113-120.

Suarez, V.H., and J. Cabaret. 1991. Similarities between species of the Ostertagiinae (Nematoda: Trichostrongyloidea) in relation to host-specificity and climatic environment. Systematic Parasitology 20:179-185.

Sykes, A.R. 1978. The effect of subclinical parasitism in sheep. Veterinary Record 102:32-34.

Syroechkovskij, E.E. 1995. Wild reindeer. Washington, DC: Smithsonian Institution Libraries, $290 \mathrm{pp}$.

Thomas, R.J. 1959. A comparative study of the life histories of Nematodirus battus and $N$. filicollis, nematode parasites of sheep. Parasitology 49:374-386.

Thorne, E.T., E.S. Williams, W.M. Samuel, and T.P. Kistner. 2001. Diseases and parasites. In Ecology and management of the North American elk, 2nd ed. Ed. J.W. Thomas and D.E. Toweill. Washington, D.C.: Smithsonian Institution Press. Forthcoming.

Thornton, J.E., T.J. Galvin, and R.R. Bell. 1973a. Parasites of the blackbuck antelope (Antilope cervicapra) in Texas. Journal of Wildlife Diseases 9:160-162.

Thornton, J.E., T.J. Galvin, R.R. Bell, and C.S. Ramsey. 1973b. Transmissibility of gastrointestinal nematodes from blackbuck antelope to cattle, sheep and goats. Journal of the American Veterinary Medical Association 163:554-555.
Threlfall, W. 1969. Further records of helminths from Newfoundland mammals. Canadian Journal of Zoology 47:197-201.

Uhazy, L.S., and J.C. Holmes. 1971. Helminths of the Rocky Mountain bighorn sheep in western Canada. Canadian Journal of Zoology 49:507-512.

Van Baren, D.C., E.P. Hoberg, and R.G. Botzler. 1996. Abomasal parasites in tule elk (Cervus elaphus nannodes) from Grizzly Island, California. Journal of the Helminthological Society of Washington 63:222-225.

Van Vuren, D., and C.A. Scott. 1995. Internal parasites of sympatric bison, Bison bison, and cattle, Bos taurus. Canadian Field Naturalist 109:467-469.

Vitousek, P.M., C.M. D'Antonio, L.L. Loope, and R. Westbrooks. 1996. Biological invasions as global environmental change. American Scientist 84:468-478.

Waid, D.D., D.B. Pence, and R.J. Warren. 1985. Effects of season and physical condition on the gastrointestinal helminth community of white-tailed deer from the Texas Edwards plateau. Journal of Wildlife Diseases 21:264-273.

Walker, M.L., and W.W. Becklund. 1970. Checklist of the internal and external parasites of deer, Odocoileus hemionus and $O$. virginianus, in the United States and Canada. Special Publication 1. Index Catalogue of Medical and Veterinary Zoology. Washington, DC: U.S. Department of Agriculture, Agricultural Research Service, U.S. Government Printing Office, $45 \mathrm{pp}$.

Webster, W.A., and J. Rowell. 1980. Some helminth parasites from the small intestine of free-ranging muskoxen $O v i$ bos moschatus (Zimmermann) of Devon and Ellsemere Islands, Northwest Territories. Canadian Journal of Zoology 58:304-305.

Williams, J.E. 1986. Epidemiological patterns of nematodiasis in cattle. Veterinary Clinics of North America: Food Animal Practice 2:235-246.

Wilson, G.I. 1969. Some parasites of elk in New Mexico. Journal of Wildlife Diseases 5:23-24.

Woodford, M.H., and P.B. Rossiter. 1994. Disease risks associated with wildlife translocation projects. In Creative conservation: Interactive management of wild and captive animals. Ed. P.J.S. Olney, G.M. Mace, and A.T.C. Feistner. London, UK: Chapman and Hall, pp. 179-200.

Worley, D.E. 1979. Parasites and parasitic diseases of elk in the Northern Rocky Mountain region: A review. In North American elk: Ecology, behavior and management. Ed. M.S. Boyce and L.D. Hayden-Wing. Laramie: University of Wyoming Press, pp. 206-211.

Worley, D.E., and C.D. Eustace. 1972. Prevalence of helminth parasites in mule deer from eastern Montana. Proceedings of the Helminthological Society of Washington 39:135-138.

Worley, D.E., and F.M. Seesee. 1992. Gastrointestinal parasites of bighorn sheep in western Montana and their relationships to herd health. Biennial Symposium North American Wild Sheep and Goat Council 8:202-212.

Worley, D.E. and G.A.M. Sharman. 1966. Gastritis associated with Ostertagia bisonis in Montana range cattle. Journal of the American Veterinary Medical Association 149:1291-1294

Xiao, L. and H.C. Gibbs. 1991. Abomasal nematodes from white-tailed deer (Odocoileus virginianus) in Maine. Journal of the Helminthological Society of Washington 58:198-201

Zarlenga, D.S., F. Stringfellow, M. Nobary, and J.R. Lichtenfels. 1994. Cloning and characterization of ribosomal RNA genes from three species of Haemonchus (Nematoda: Trichostrongyloidea) and identification of PCR primers for apid differentiation. Experimental Parasitology 78:28-36.

Zaugg, J.L., S.K. Taylor, B.C. Anderson, D.L. Hunter, J. Ryder, and M. Divine. 1993. Hematologic, serologic values, histopathologic and fecal evaluations of bison from Yellowstone Park. Joumal of Wildlife Diseases 29:453-457. 